\title{
التجسيد الاستورى لذوى الاحتياجات الخاصة وحقوقهم فى ضوء المواثيق والتشريعاث الدولية دراسة مقارنة بين النظامين المصرى والسعودى
}

\author{
الاكتور \\ محمود عبد السلام تقي الدين \\ دكتوراه القانون العام \\ كلية الحقوق - جامعة عين شمس العسان
}





\section{المستخلص}

يشكل الاهتمام بحقوق ذوى الاحتياجات الخاصة جزء مهما فى القانون الدولى الإنى

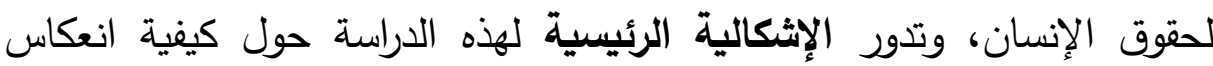

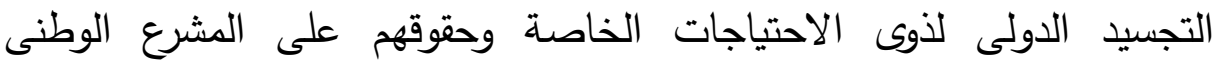
الدستورى والقانونى، وقد تبين من مراجعة الدراسات السابقة أن كلا من القانون

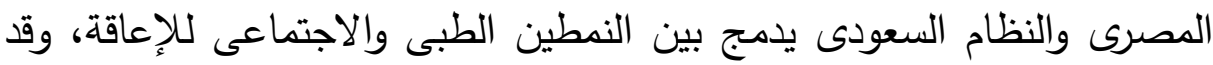
وضعت الاتفاقية الدولية لحقوق الأشخاص ذولى لين الإعاقة تنظيماً شاملاً وكاملاً

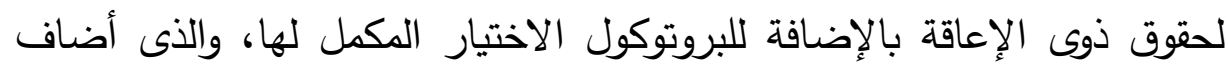

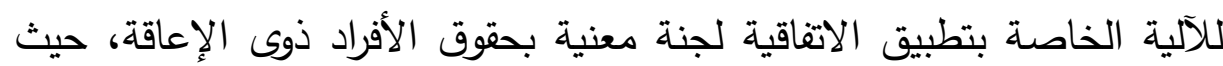

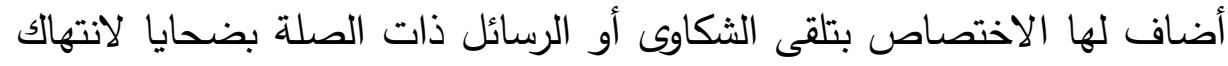

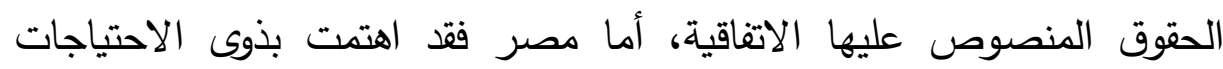

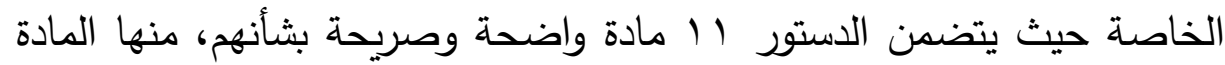

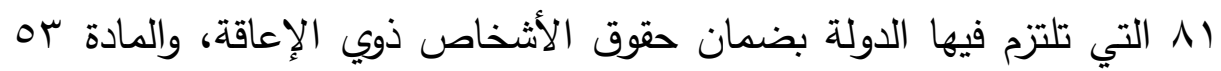

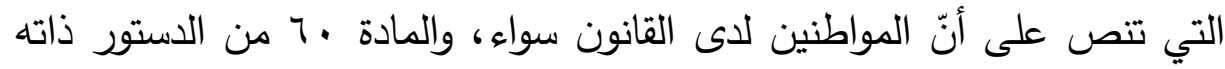

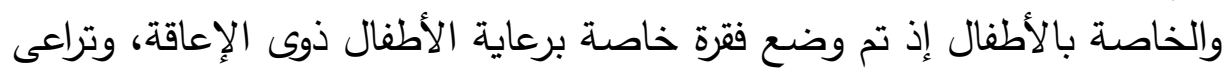

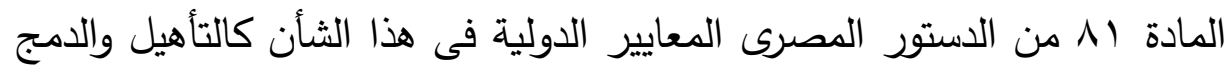

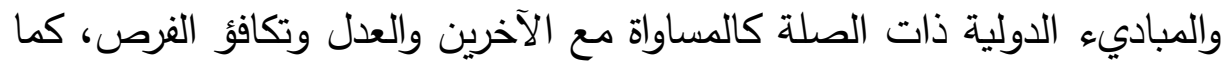
أضاف هذا القانون تفسيرا للدمج، وقد جسد النظام السعودى ذوى ذاءل الاحتياجات

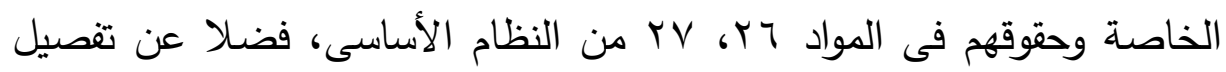
نظام رعاية شؤون المعوقين لحقوقهم فى شتى المجالات كالمجال الصحى الصى

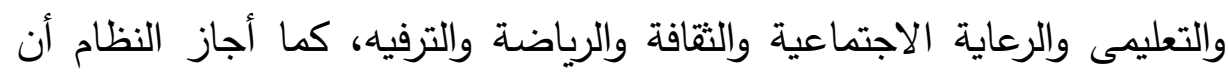

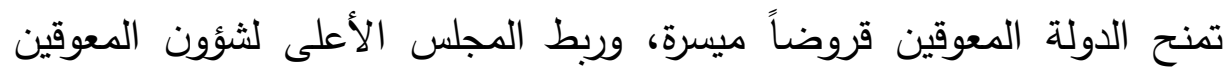

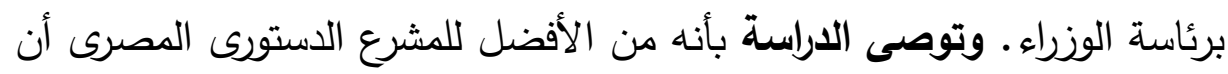

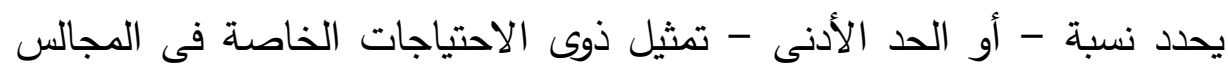

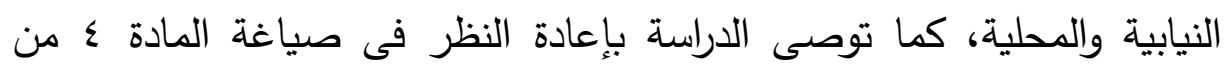

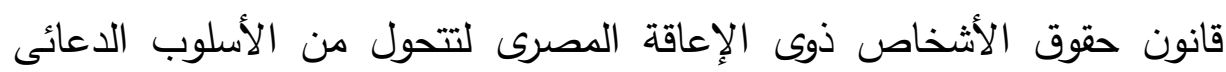

لخطوات تنفيذية. 


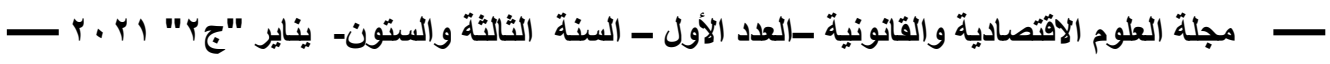

الكلمات الدلالية: الدستور - الإعاقة - ذوى الاحتياجات الخاصة - حقوق الإنسان - القانون الدولى - القانون المصرى - النظام السعودى.

\section{توطئة}

يشكل الاهتمام بحقوق ذوى الاحتياجات الخاصة جزء مهما فى القانون

الدولى لحقوق الإنسان، وذلك لضمان تكافؤ الفرص والمساواة في الحقوق لجميع الأشخاص ذوي الإعاقة، ويشمل ذلك العمل جنباً إلى جنب لتحقيق أهداف ومطالب مثل إمكانية الوصول والسلامة في الهندسة المعمارية والنقل والبيئة المادية؛ وتكافؤ الفرص في العيش المستقل، والإنصاف فى العمل، والتعليم، والإسكان؛ والتحرر من التمييز والإساءة والإهمال ومن انتهاكات الحقوق

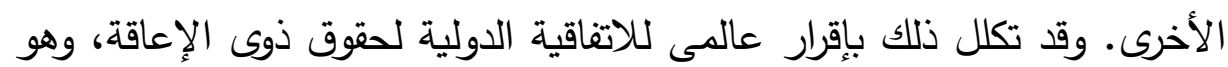
الأمر الذى استدعى تدخل المشرع الوطنى العربى لإجراء تعديلات دستورية وقانونية تعكس الالتزام الدولى بتلك الاتفاقية، وحتى يواكب غيره من مشرعى العالم، وكلا من مصر والسعودية استجاب لهذا المطلب العالمى الإنسانى

$$
\text { بخطوات سريعة تستدعى دراستها.' }
$$

\section{إثكالية الاراسة وتساؤلاتها}

تدور الإثكالية الرئيسية للبحث فى كيفية انعكاس التجسيد الدولى لذوى الاحتياجات الخاصة وحقوقهم على المشرع الوطنى الدستورى والقانونى، وينبثق عن تلك الإشكالية التساؤلات الآتية: 1. إ مفهوم ذوى الاحتياجات الخاصة؟ r. كيف جسد القانون الدولى ذوى الاحتياجات الخاصة وحقوقهج? r. كيف جسدت التشريعات المختلفة ذوى الاحتياجات الخاصة وحقوقهم؟

راجع فى هذا الصدد: حقوق المعاقين فى إطـار الاتفاقات الدولية والعربية، مكتبة الوفاء

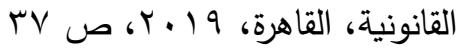

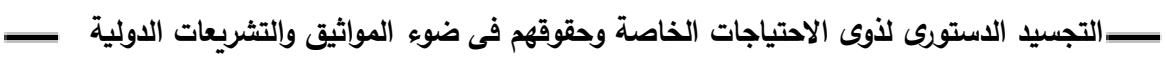

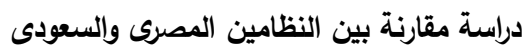




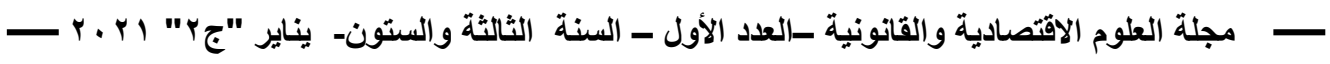

ع. كيف انعكس تجسيد الدستور المصرى لذوى الاحتياجات الخاصة وحقوقهم على

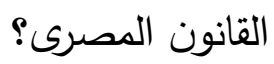

○. كيف انعكس تجسيد النظام الأساسى السعودى لذوى الاحتياجات الخاصة

وحقوقهم على النظام السعودى؟

منهج الدراسة

سيتم إجراء هذه الدراسة وفق منهج وصفى تحليلى فيما يتعلق بالثق

الدولى، ومنهج مقارن فيما يتعلق بالثق الوطنى.

\section{تقسيم الدراسة}

ستقسم هذه الدراسة لمطلب تمهيدى يجرى فيه بحث الاطار المفاهيمى لذوى الاحتياجات الخاصة، ثم يخصص مبحث أول لبحث تجسيد ذوى الاحتياجات

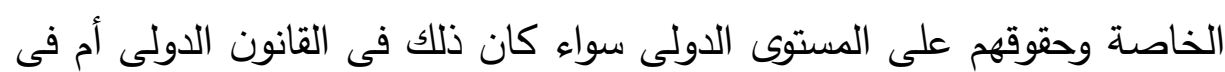
التشريعات المختلفة، ثم يخصص مبحث ثانى لبحث التجسيد الدستورى لذوى الاحتياجات الخاصة وحقوقهم فى مصر والسعودية

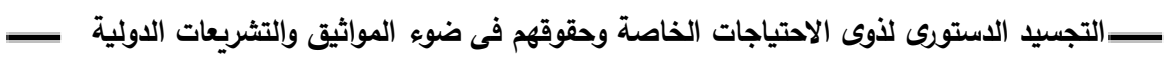

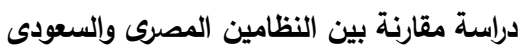




\section{مطلب تمهيدى \\ الإطار المفاهيمى لذى الاحتياجات الخاصة}

ا ـ التعريفات اللغويـة

المعاق لغة مشتق الفعل "عاق", وعاق الثيء أى منعه منه وشغله عنه،

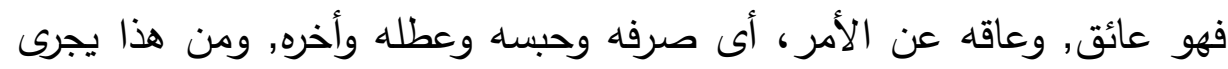

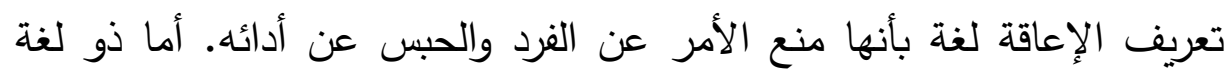

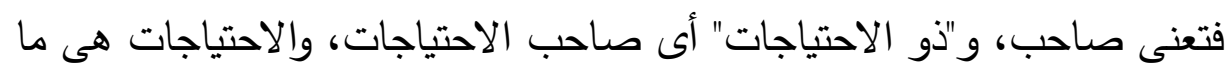

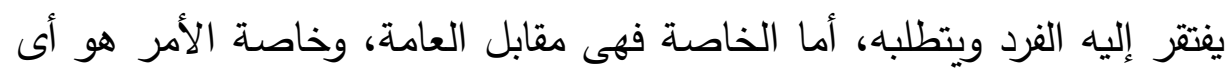
ما يتم تخصيصه به دون غيره.

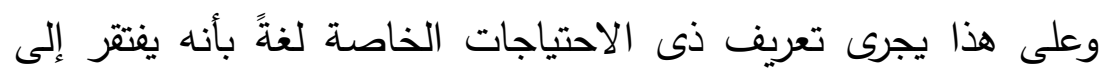
بعض الأشياء فيطلبوها أو تُطلب له له ليحقق ما يحتاجه.

r. التعريفات الاصطلاحية

التعريف الفقهى لذى الاحتياجات الخاصة الاصطية

كانت كلمة "معوق" تستخدم فى هيئات ومؤسسات غالاجية البية الدول خاصة

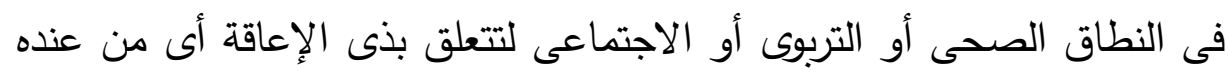

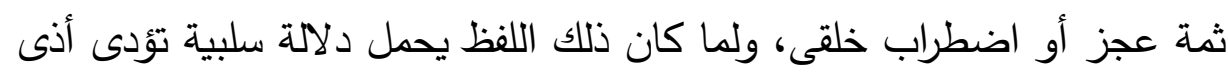

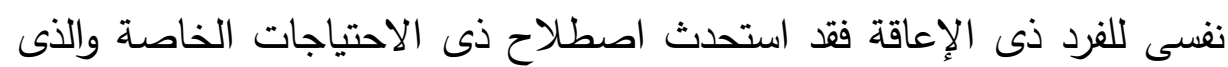

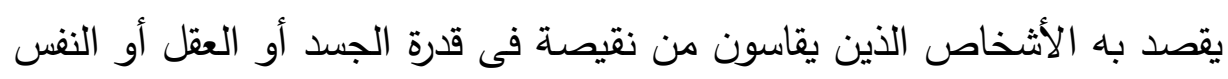

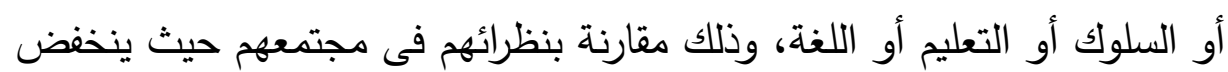

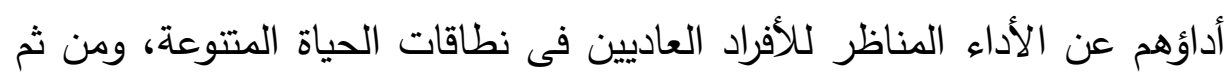
فهم فى حاجة للمساعدة لأجل التكيف المجتمعى، وذلك ليستطيعوا مزاولة الحياة

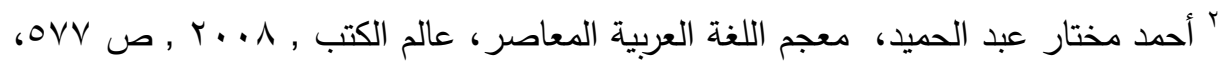

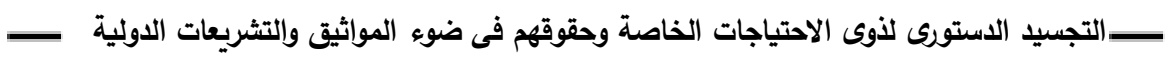
دراسة مقارنة بين النظامين المصرى والسعودى في الكيات 
بشكل طبيعى. كما يمكن تعريف ذى الاحتياج الخاص بأنه فرد يعانى على إثر

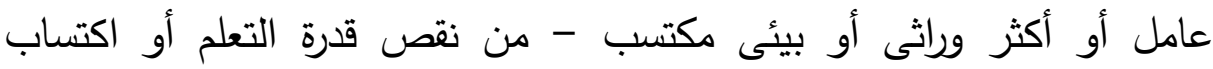
الخبرات أو المهارات - فى نواحى الثقافة أو الاقتصاد أو الاجتماع - وأداء

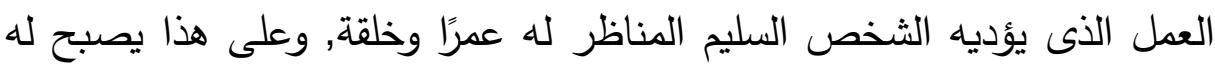
فضلا عن حاجات الثخص العادى حاجات فعلية ونفسية وحياتية ومهنية

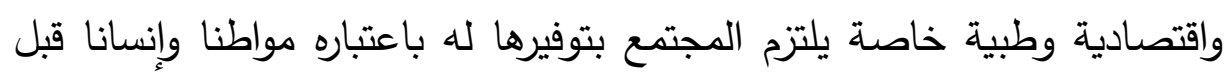
أن يكون معاقا.

\section{تعريف القانون المصرى لذى الإعاقة}

تعرف المادة الثانية من قانون حقوق الأشخاص الاصنه ذوى الإعاقة المصرى

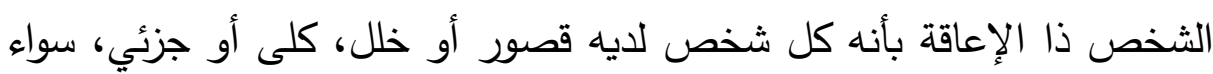

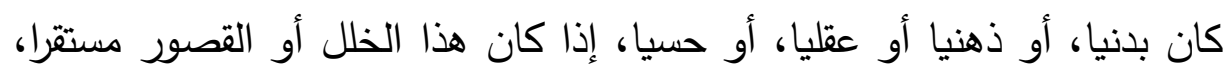

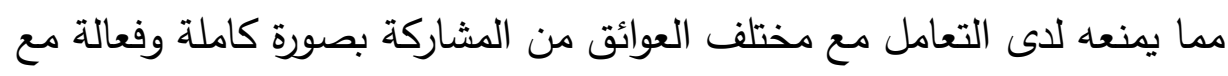

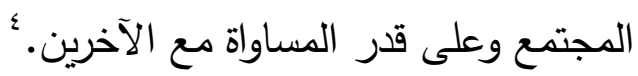
وقد أوضحت اللائحة التنفيذية لذات القانون أنه يتم تحديد حالات

$$
\text { الإعاقة من خلال المرحلتين الآتيتين: }
$$

- المرحلة الأولى: تعتمد على التقييم الطبى للشخص المتقدم للحتين: للحصول على بطاقة

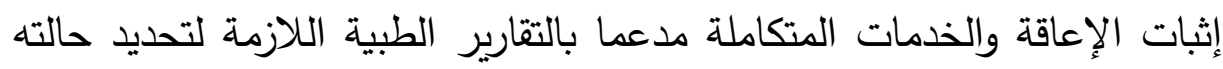
والتى تؤكد وجود إصابة أو مرض أو حالة مرتبطة بالإعاقة.

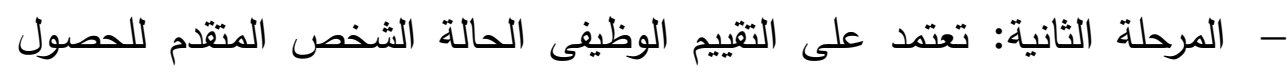
على بطاقة إثبات الإعاقة والخدمات المتكاملة لتحديد مدى الصعوبات الوظيفية

r 'وسيم حسام الدين الأحمد , الحمايـة القانونية لحقوق المعاقين ذوى الاحتياجـات الخاصـة,

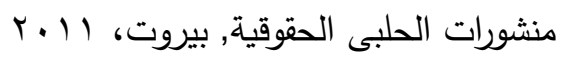

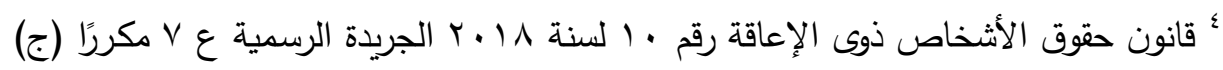

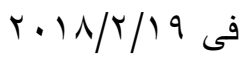

$1 \% 10$

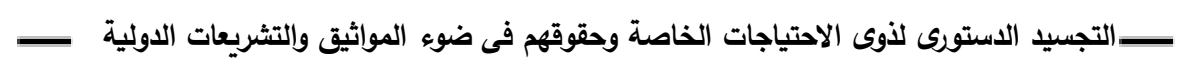

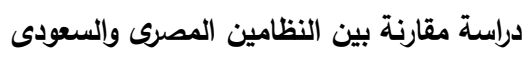


التى يواجهها فى تأدية أنشطة الحياة اليومية نتيجة القصور أو الخلل المحدد بالتقييم الطبى.

تعريف النظام السعودى للإعاقة ولذى الإعاقة

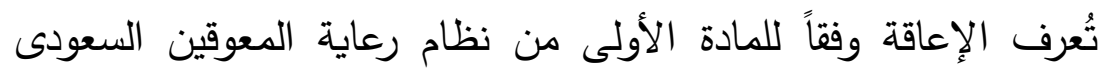
بأنها "الإصابة بواحدة أو أكثر من الإعاقات الآتية: الإعاقة البصرية، الإعاقة رعابهة

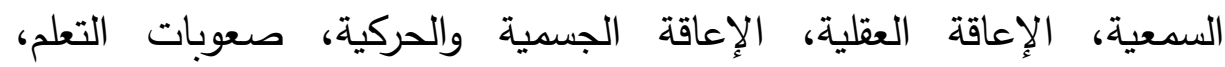

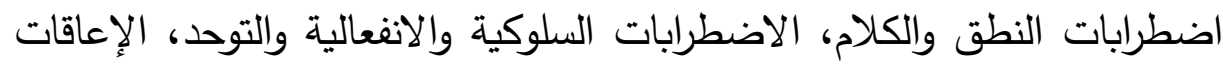

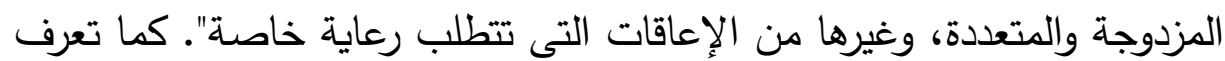

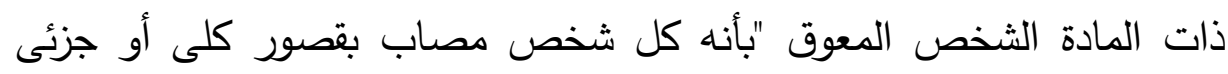
بشكل مستقر فى قدراته الجسمية أو الحسية أو العقلية أو التواصلية أو التعليمية المانية أو النفسية إلى المدى الذى يقلل من إمكان تلبية متطلباته العادية فى ظروف

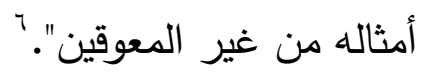
ويتبين من هذا أن كل من القانون المصرى والنظام السعودى يدمج بين النمطين الطبى والاجتماعى للإعاقة، إذ يرتبهما الأول بثكل صني صريح بينما يعتبر

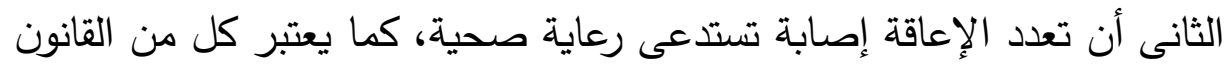

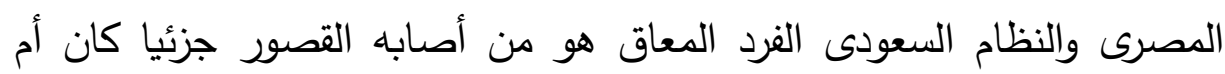
شاملا على وجه الاستقرار، فديمومة القصور هى التى تمنعه من تحصيل حقه هن الته

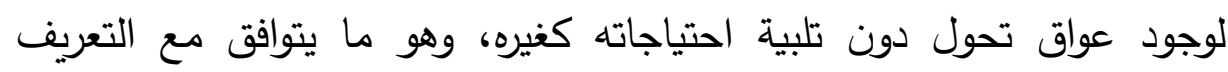
الاجتماعى للإعاقة ومضامين الأجل الطويل.

\section{r. أنواع الإعاقة}

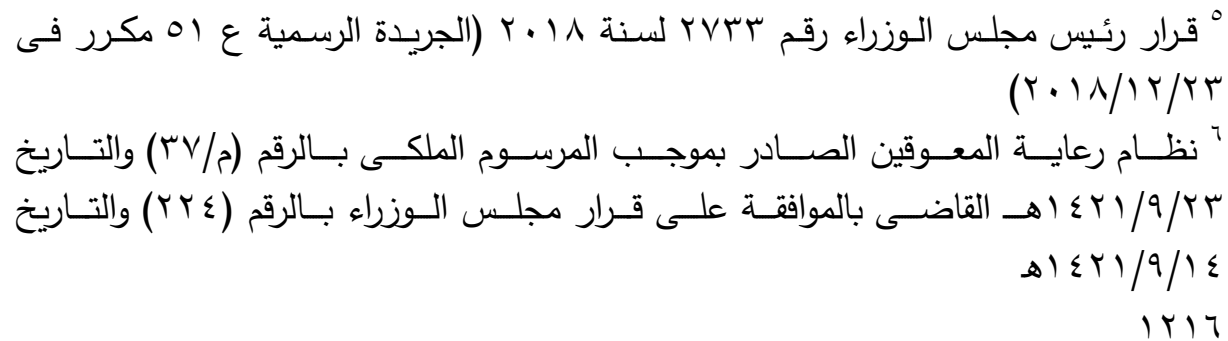

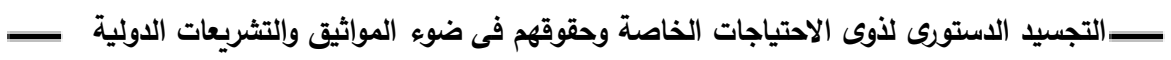

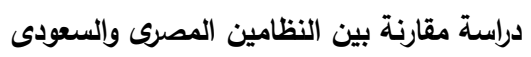




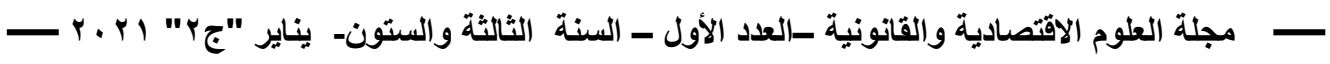

اعتاد الفقه على تصنيف ذوى الاحتياجات الخاصة حسب نوعية الإعاقة

$$
\text { إلى أربعة أصناف أساسية وهى: الأى الصاد }
$$

أ. الإعاقات الجسمية الفيزيائية: ومن أمثلتها ذوى العاهات الجسية الجية كالمقعدين والأقزام ومبتورى والمصابين بشلل الأطفال والثلل الدماغى وغيرهم، وذوى تونى

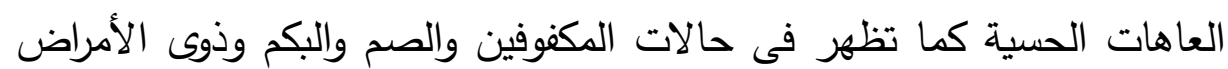
المزمنة.

ب. الإعاقات العقلية: وتتمثل فى من لديهم نقص فى الذكاء عن المستوى الطبيعى

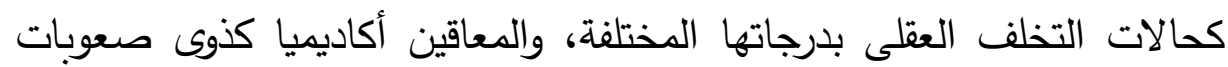

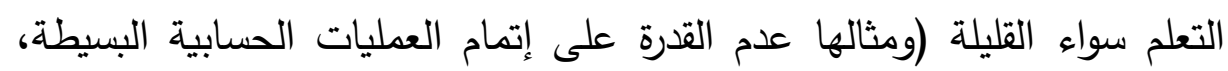

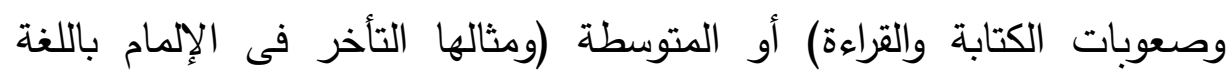

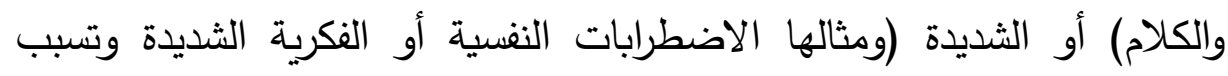
تشتيت الانتباه وصعوبة التواصل مع الآخرين).

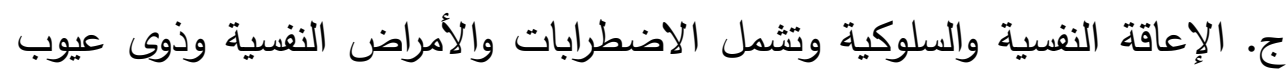

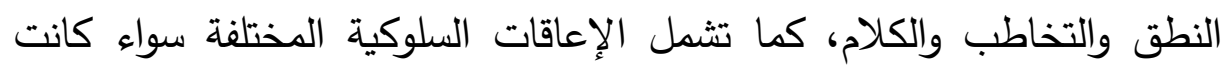

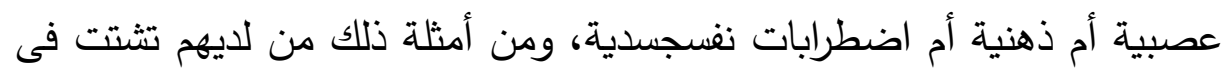
الانتباه أو مرض التوحد، وكذلك اضطراب الوسواس القهرى أو اضطراب العناد الثديد أو الغضب ومرض الاضطراب السلوكى العاطفى واضطراب فرط الحركة.

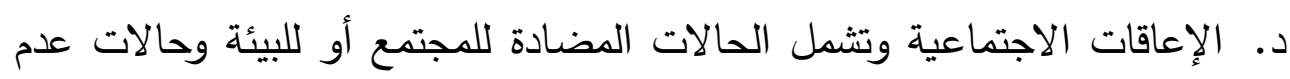

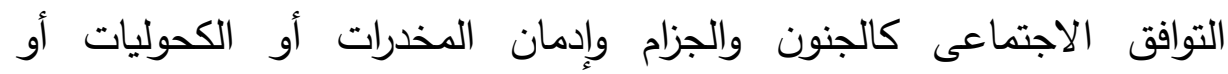

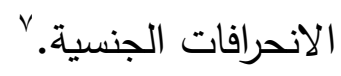

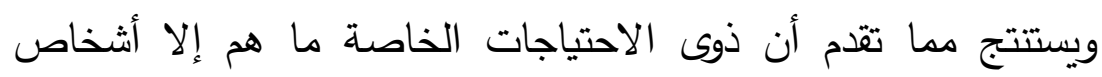

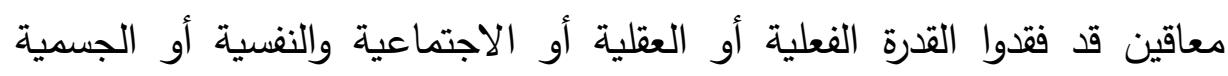

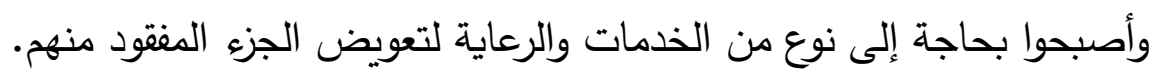
ـ. أهم المشاكل التى يعانيها ذو الاحتياجات الخاصة نون

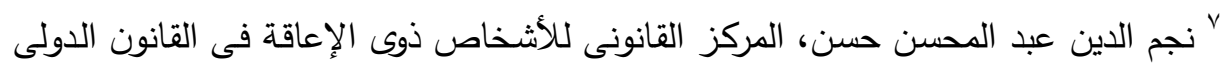

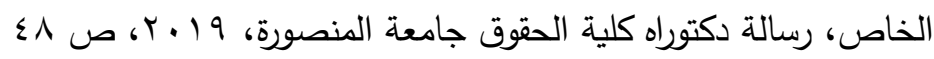

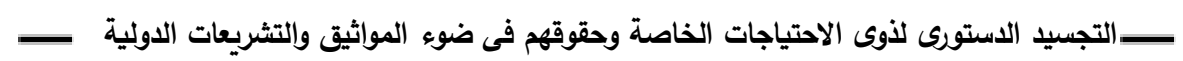
دراسة مقارنة بين النظامين المصرى والسعودى في الكيات 
- مشكلة النمو: وهى من أهم المشاكل التى يقابلها الأطفال من ذوى الاحتياجات

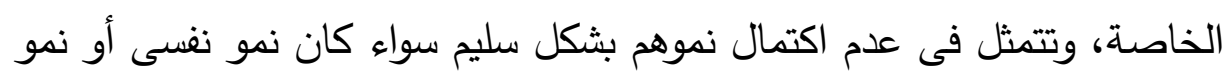
عقلى لا يتناسب طرديا مع نموهم الجسدى مما يجعلهم يعيشون مرحلة عمرية عقلية أقل من سنهم الحقيقى.

- مثكلات التعليم وصعوبات التعلم: تتسبب قلة الخبرة لدى الوالدين فى أساليب التعامل مع الأطفال من ذوى الاحتياجات الخاصة ومحاولة تجنب مشاكلهم

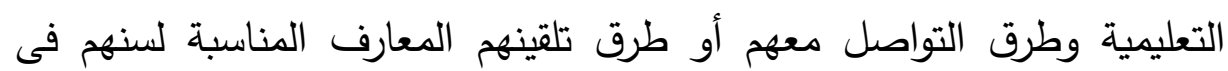

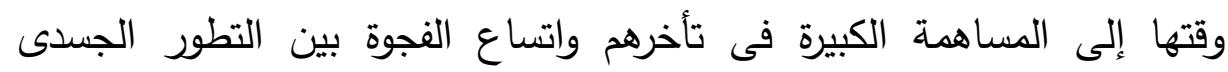
والعقلى لهم. - - المشكلات السلوكية: تنتج عند الأطفال ذوى الاحتياجات الخاصة نتيجة معاناتهم

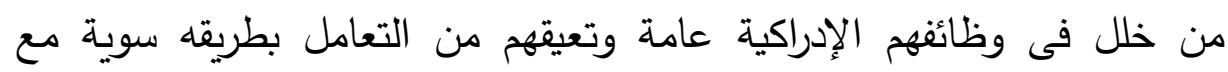
الآخرين، بالإضافة إلى صعوبة التأقلم فى الحياة.

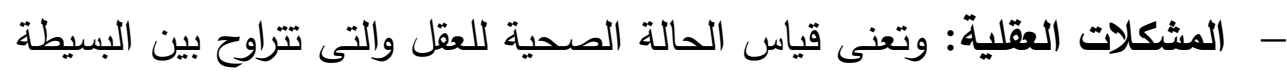

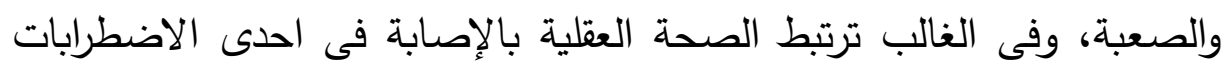

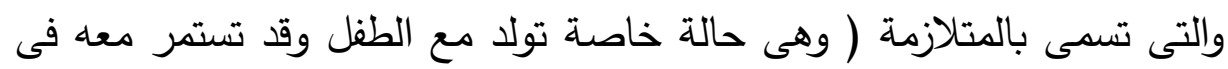

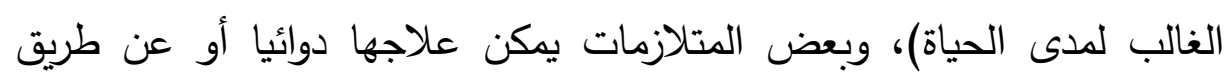

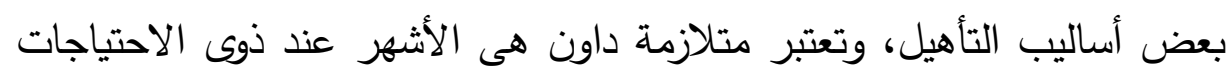

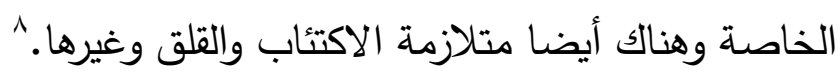

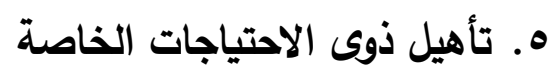

عملية التأهيل habilitation هى تلك العملية المنظمة والمستمرة التى دوات تسعى لأن تصل بالشخص ذى الإعاقة لدرجة مدكنة فى المجال الصحى

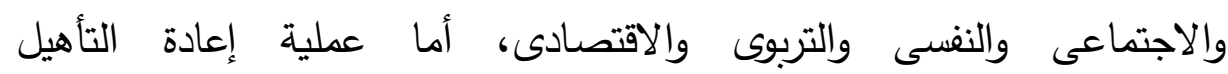
rehabilitation

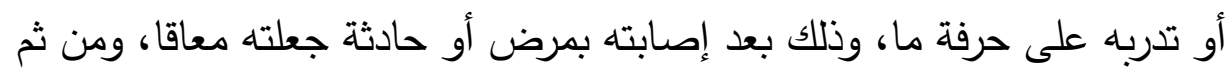

^ عبد المنعم على عمرو، سيكلوجية ذوى الإعاقة، الدار العالمية للنشر والتوزيع، القاهرة،

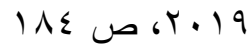


لا يستطع الرجوع لعمله أو لمهنته السابقة بسبب الإعاقة، أما التأهيل الثامل فهو

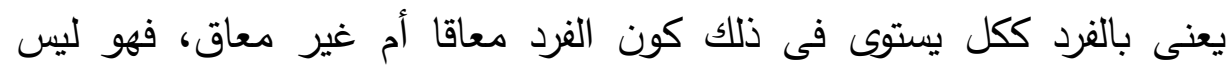

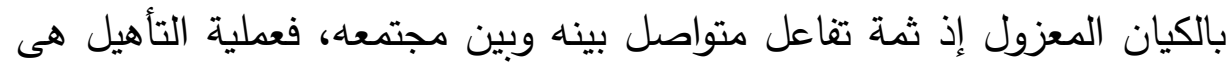
بمثابة مسؤولية مجتمعية تخص كل الأفراد وتتطلب تخطيطا وعملا ودعما اجتماعيا على جميع الأصعدة، ومرد ذلك أن التأهيل ينقل الثخص من من شخص لديه قصور لشخص قادر على القيام بأعمال تتناسب مع دع ما لديه من إمكانيات. وقد عرف القانون المصرى التأهيل المجتمعى بأنه إستراتيجية فى إطار تتمية المجتمع، تعمل وتقوم على تأهيل الأشخاص ذوى الإعاقة وتمكينهم من

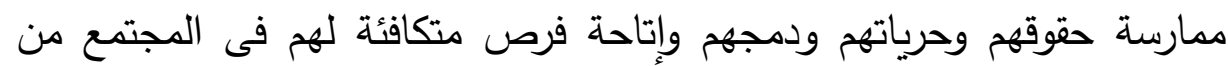

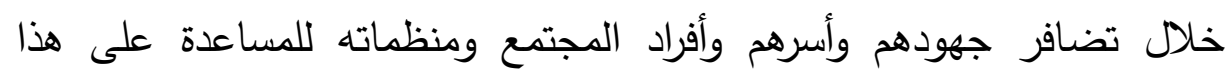

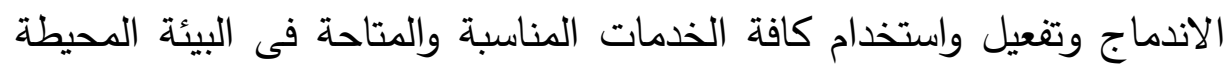
والمجتمع. كما يعرف القانون المصرى التأهيل بأنه الخدمات متعددة العناصر والثاته والمناسبة لكل شخص من ذوى الإعاقة التى تهدف إلى تمكين الشخص ذئ دانى

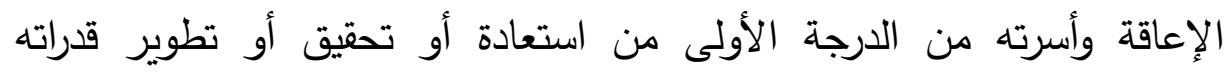

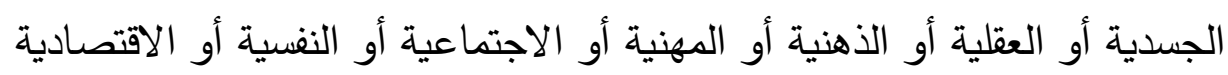

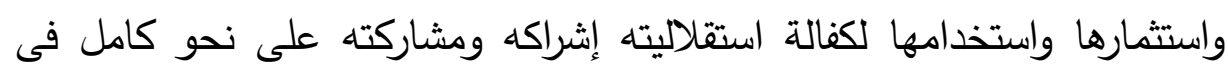
جميع مناحى الحياة وذلك على قدر المساواة مع الآخرين. بينما يعرف النظام السعودى التأهيل بأنه عملية منسقة لتوظيف الخدمات الطبية والإجتماعية والنفسية والتزبوية والمهنية لمساعدة المعوق فى تحقيق أقصى درجة ممكنة من من فئه الفاعلية الوظيفية، بهدف تمكينه من التوافق مع متطلبات بيئته الطبيعية

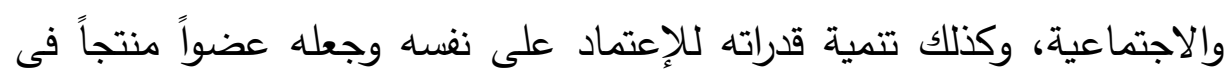
المجتمع ما أمكن ذلك. ويلاحظ أن القانون المصرى لم يفرق بين مصطلح التأهيل ووسائله،

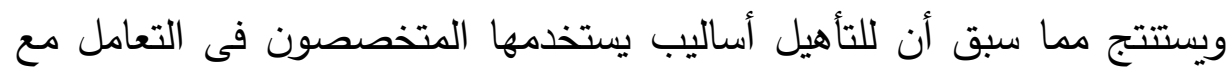

9 أحمد صلاح الدين رجب دسوقى، أثر ممارسة الأنشطة الطلابية على دمج ذوى الاحتياجات

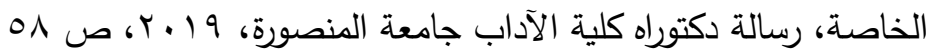

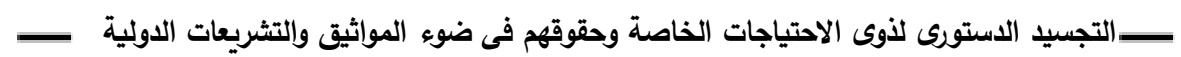

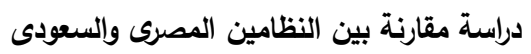


ذوى الاحتياجات الخاصة، وذلك لمساعدتهم على التكيف والتأقلم مع الناس فى المجتمع المحيط بهم، عن طريق دمجهم فى بيئتهم المتواجدون بها ومساعدة ولهات أهلهم فى معرفة التعامل معهم.

\section{المبحث الأول}

تجسيد ذوى الاحتياجات الخاصة وحقوقهم على المستوى الدولى الاولى

المطلب الأول

\section{تجسيد ذوى الاحتياجات الخاصة وحقوقهم فى المواثيق الدولية}

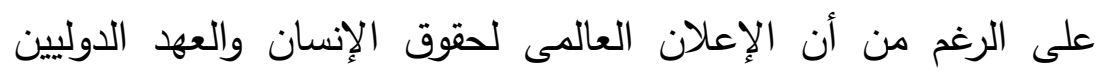

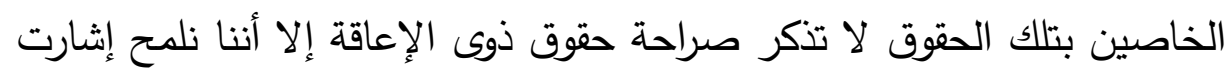

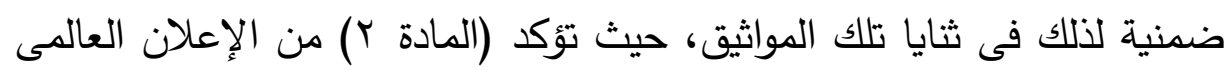

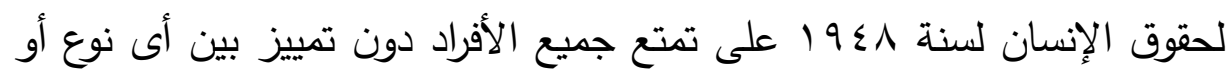

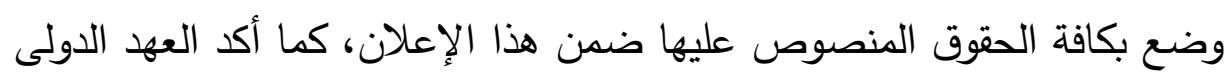
الخاص بالحقوق الاجتماعية والاقتصادية والثقافية لسنةج4و 197 على عدم التمييز

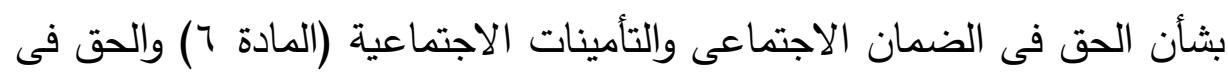

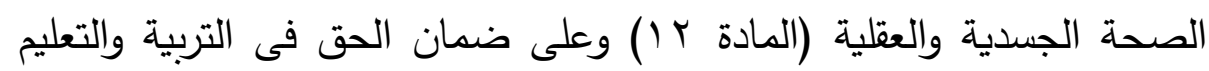
(المادة ب ())، وأخيرا أشار العهد الدولى الخاص بالحقوق المدنية والسياسية لسنة 1977 إلى الحق فى الحياة وما يتصل به دن حق الفرد فى سلامة شخصه الفها

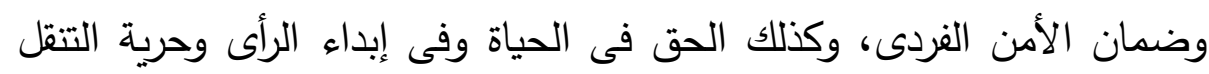

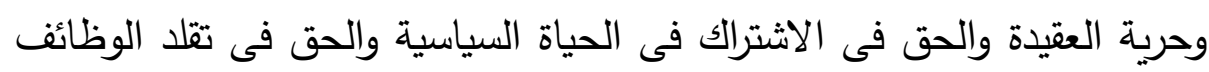

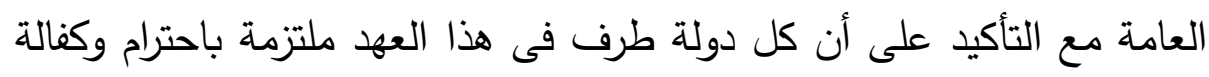

Ir

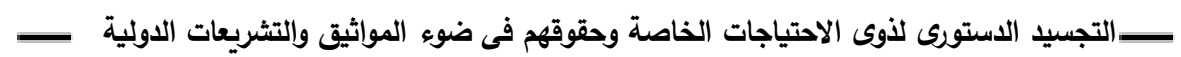

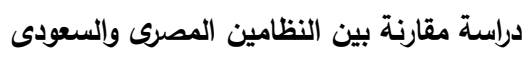


كافة هذه الحقوق لجميع الأفراد الموجودين على إقليمها والداخلين فى ولايتها دون

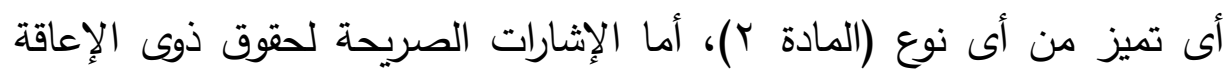

فوردت فى مواثيق خاصة منها:

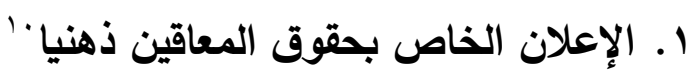

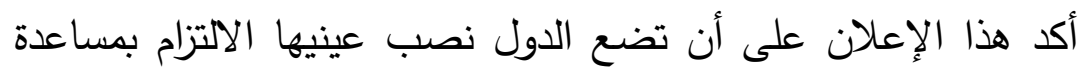

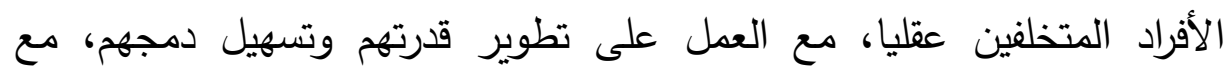

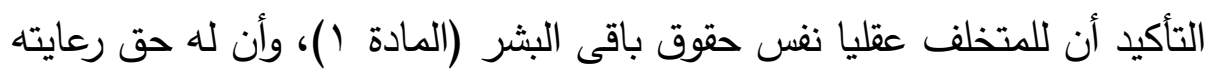
وعلاجه وتدريبه وتأهيله وتعليمه وتوجيهه بما يلزم لتطوير قدرته وطاقته (المادة

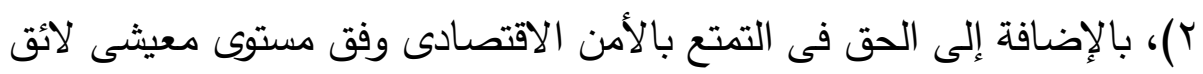

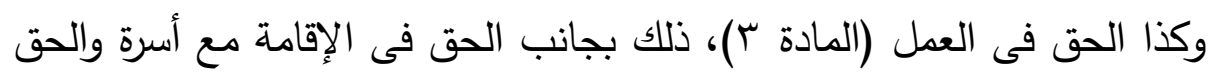

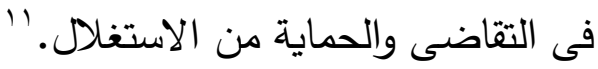

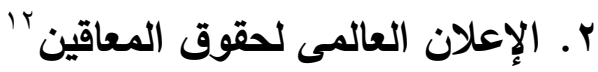

يعد هذا الإعلان بمثابة الأساس الذى اعتمدت عليه معظم دساتير وقوانين الدول لتكريس حقوق المعاقين؛ إذ يقوم هذا الإعلان بتعريف المعاق الإن الإني

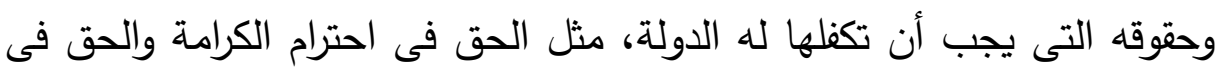

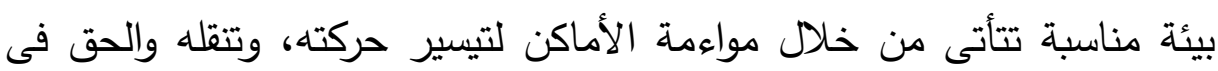

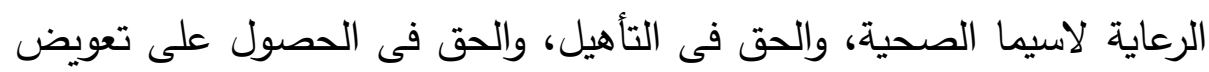

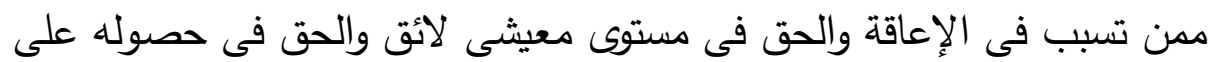

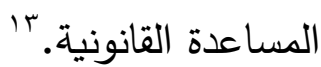

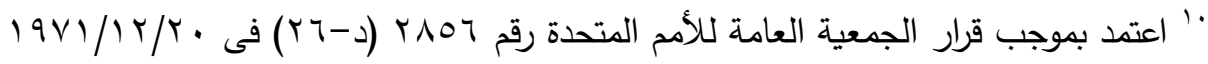

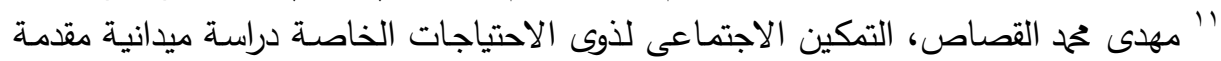

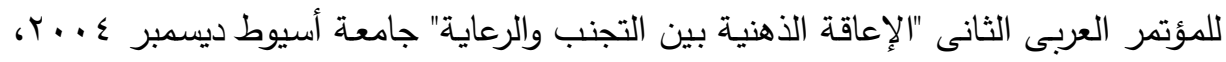
ص آ IT

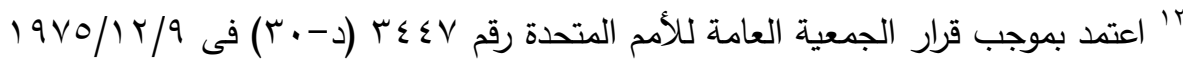
"Mark C. Weber, Protection for Privacy under the United Nations Convention on the Rights of Persons with Disabilities, 
r. مبادئ حماية الأثخاص المصابين بمرض عقلى وتحسين العناية بالصحة

العقلية؛

يجب تطبيق هذه المبادئ دون تمييز مهما كان دافعه، كالتمييز بسبب

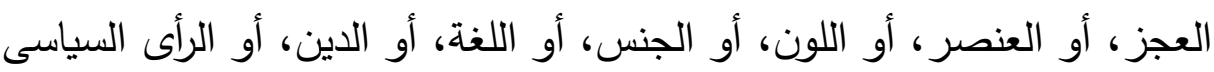

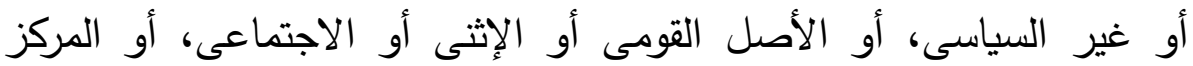

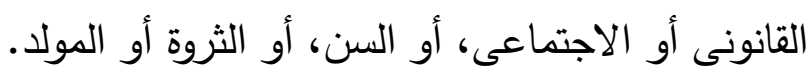

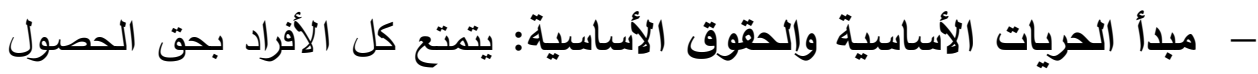

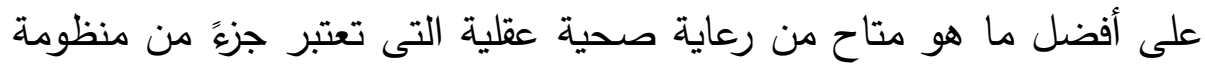

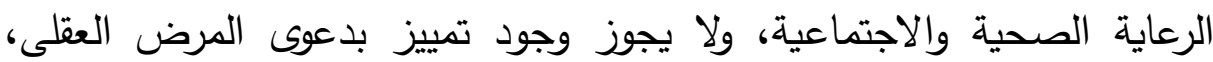

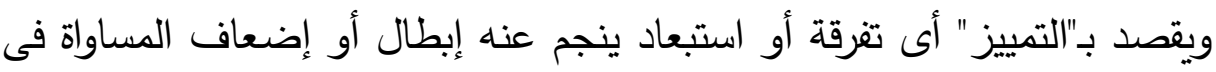

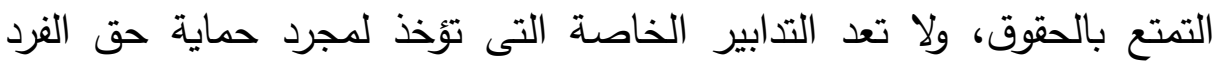

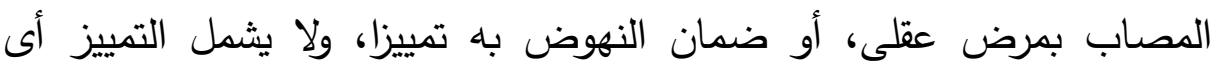

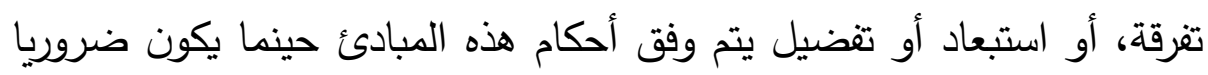

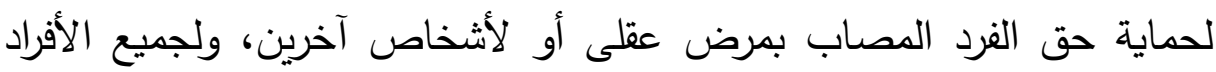

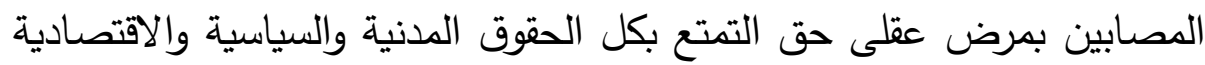
والاجتماعية والثقافية المعترف بها فى الإعلان العالمى لحقوق الإنسان، والعهد

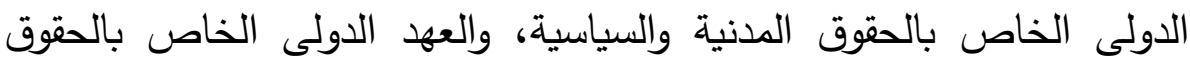

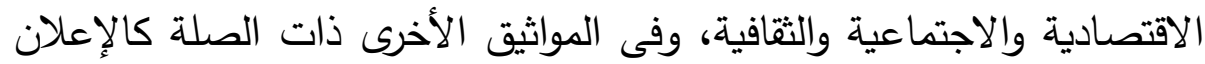

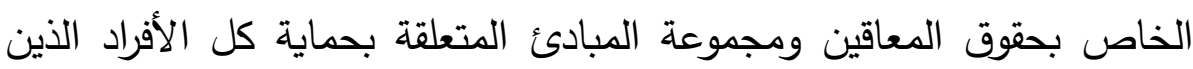
يتعرضون لأشكال تقييد الحرية المختلفة. 10

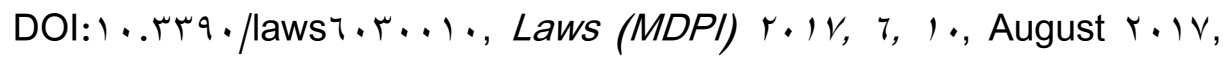
P. r

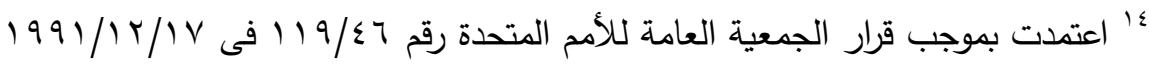
10 De Paor, Aisling, and Charles O'Mahony. The Need to Protect Employees with Genetic Predisposition to Mental Illness? The UN Convention on the Rights of Persons with Disabilities and the Case for Regulation. Industrial Law Journal $\leqslant 0, r .17, P$. or 1 
- مبدأ حماية القصر هنالك عناية خاصة - فى حدود أهداف هذه المبادئ وفى إطار القانون الوطنى ذى الصلة - لحماية حقوق القاصر، بما فيها، عند فئه الاقتضاء، تحديد ممثل خاص خارج أعضاء الأسرة.

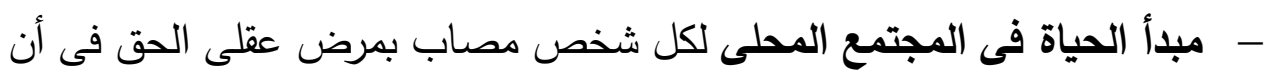

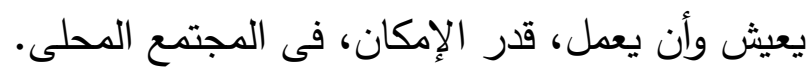

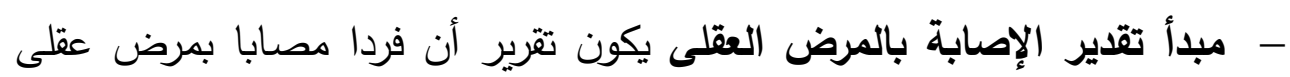

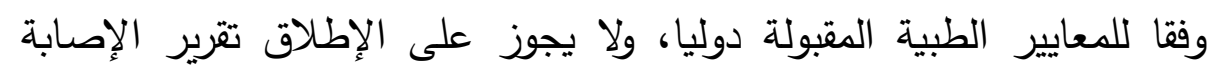

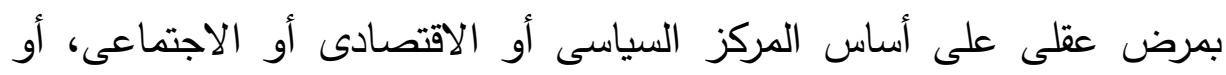

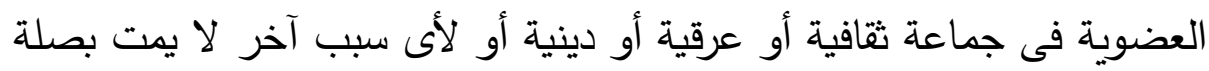
مباشرة للحالة الصحية العقلية. - مبدأ الفحص الطبى لا يجوز إخضاع أى فرد لإجراء فحص طبى بغرض تقرير

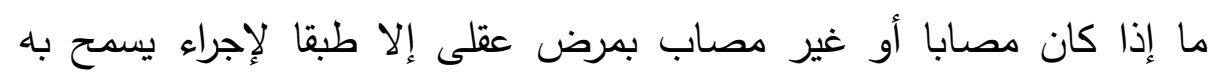

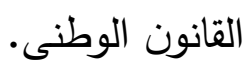
- - مبدأ السريـة يحترم الحق فى سرية المعلومات التى تتعلق بكل الأفراد الذين تطبق عليهم هذه المبادئ. - - مبدأ دور المجتمع المحلى والثقافة لكل مريض الحق فى العلاج والاعتناء به، قدر المستطاع، فى المجتمع الذى يعيش فيه. 14

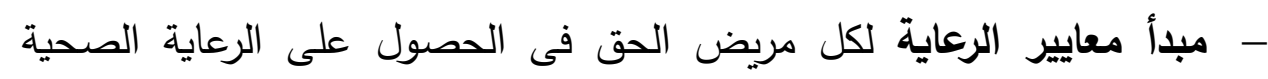
والاجتماعية التى تتاسب حاجته الصحية، كما يحق لله الحصول على الرعائ لرعل الرعاية والعلاج طبقا لذات المعايير التى تطبق على التى المرضيه التهى الآخرين.

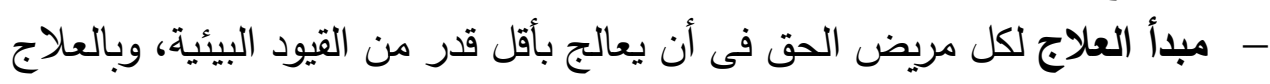

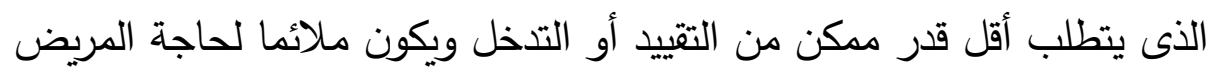

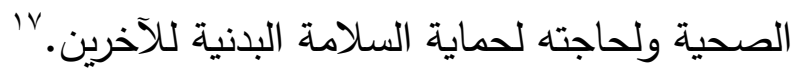

${ }^{14}$ Perlin, Michael. International Human Rights Law and Comparative Mental Disability Law: The Universal Factors. Syracuse Journal of International Law and Commerce $r \varepsilon: r \ldots v, P . r \leqslant 0$ 


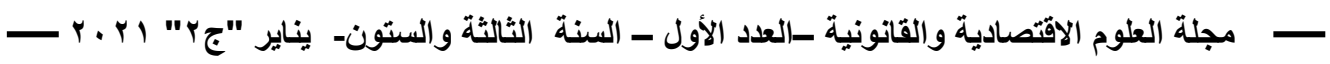

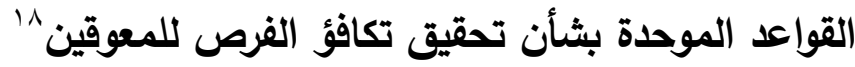 تتميز هذه القواعد بالآتى:}

ا. مطلوب من الدول تطبيق القواعد الموحدة لدى صياغة البرامج الوطنية المتصلة بالإعاقة.

r. تحث القواعد الدول على الاستجابة للطلبات التى يوجهها إليها المقرر الخاص باحثا فيها عن معلومات بشأن نفاذ القواعد الموحدة. r. مطلوب من الأمين العام تثجيع تنفيذ القواعد الموحدة وتقديم تقرير للجمعية لئان

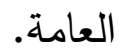

ء. . تحث القواعد الدول على مساندة نفاذ القواعد الموحدة بالوسائل المالية وبغيرها.9 19

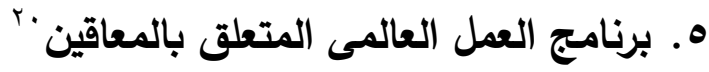

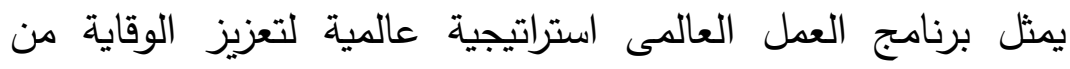
الإعاقة، وتحسين التأهيل، وتحقيق تكافؤ الفرص، وهى متعلقة بالمشاركة الكاملة

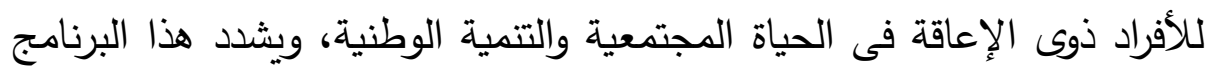
على الحاجة للتعاطى مع الإعاقة من منظور حقوقى، ويورد الإعلان تحليلا

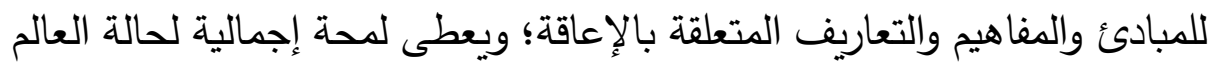

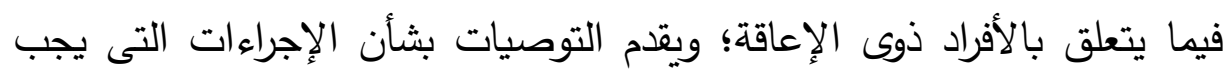

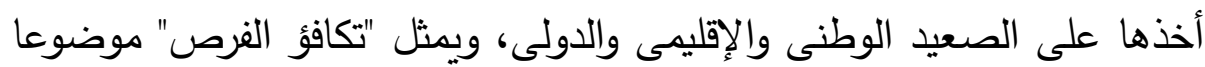

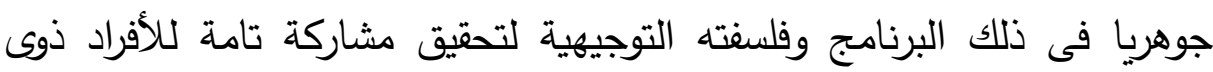

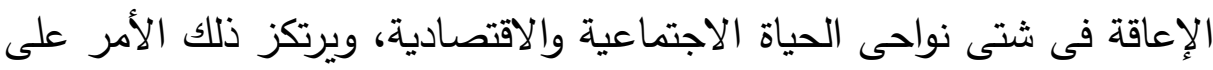

'v Dorothy Estrada-Tanck, Human Rights of Persons with Disabilities in International and EU Law, Academy of European Law, $r \cdot 17$, p. rr

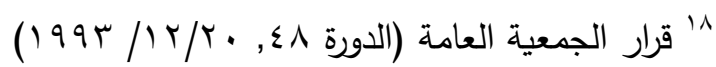
${ }^{19}$ Sara Tonolo, The protection of persons with disabilities in private international law, Cuadernos derecho transnational, March r. $\mathrm{r}, \mathrm{P}$. rvo

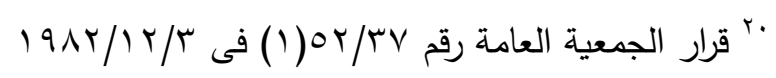

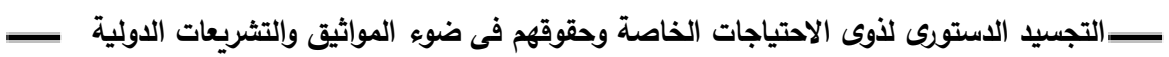

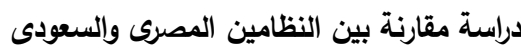


مبدأ هام وهو أهمية عدم معالجة القضايا ذات الصلة بالأفراد ذوى الإعاقة ضمن

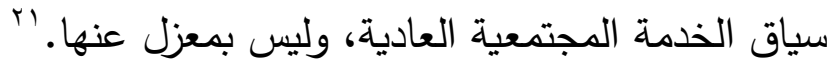

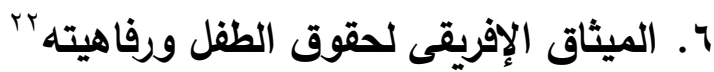

خصص الميثاق المادة 11 1 منه للأطفال المعاقين والتى قضت الطعل بالآتى: - يكون لكل طفل معاق عقلياً أو بدنياً الحق فى إجراءات خاصة للحماية تتلاءم

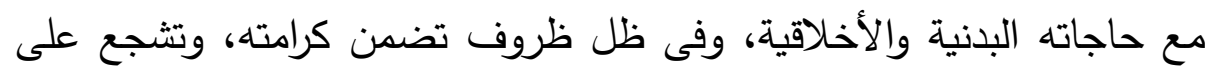

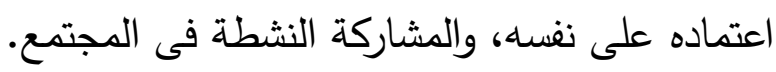
- تكفل الدول أطراف هذا الميثاق للطفل المعاق وللمسئولين عن رعايته - طبقاً

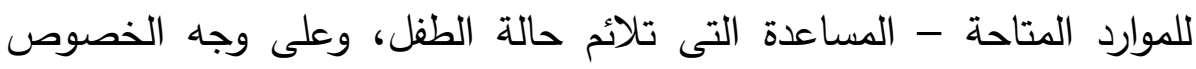

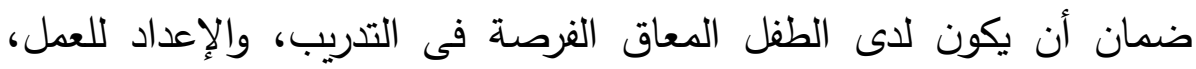
وفرص الترفيه بالشكل الذى يؤدى بالطفل إلى أن يحقق أقصى تكامل اجتماعى لإنى مدكن، وتتميته فردياً وثقافياً وأخلاقياً. - - تستخدم الدول أطراف هذا الميثاق مواردها المتاحة بهدف وتفاف تحقيق التوافق الكامل

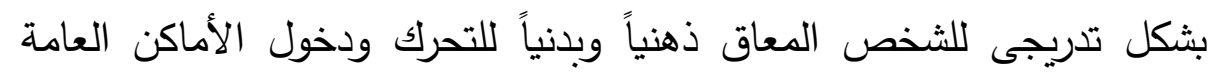

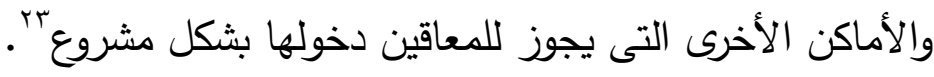

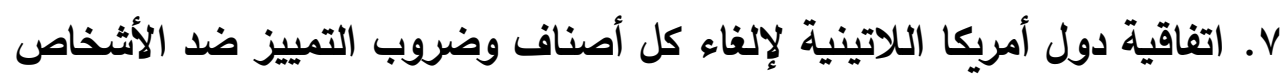
ذوى الإعاقة

ذهبت هذه الاتفاقية إلى تعديد الإجراءات والوسائل التى على الدول اتخاذها من أجل إلغاء التمييز ضد المعاقين من حيث "التسهيلات التهدئ والبراهج

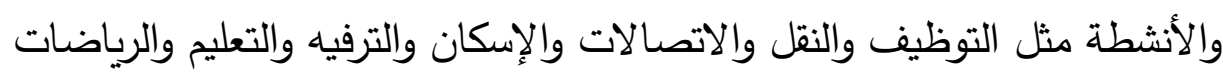

"Dorothy Estrada-Tanck, Human Rights of Persons with Disabilities in International and EU Law, op, cit., p. $\leqslant r$ 1999/11/ra بد بدأ العمل به في "Sara Tonolo, The protection of persons with disabilities in private international law, op. cit., p. $r \vee v$

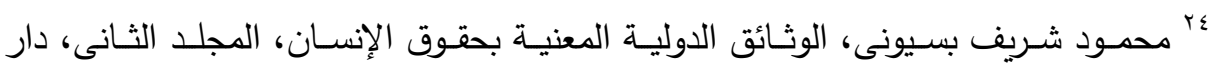

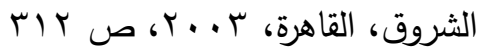


وتنفيذ القانون وتطبيق العدالة والأنشطة السياسية والإدارية، والإجراءات اللازمة

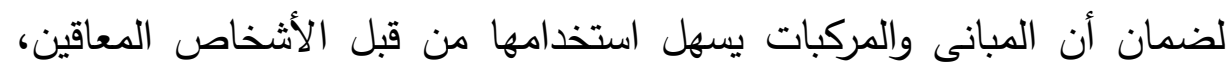
والإجراءات اللازمة لضمان أن الأشخاص المسئولين عن تطبيق هذه الاتفاقية

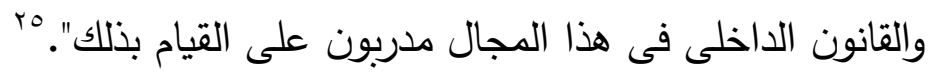

^. الاتفاقية الدولية لحقوق الأثخاص ذوى الإعاقة

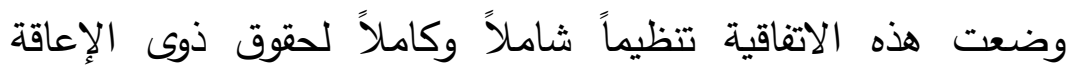
بالإضافة للبروتوكول الاختيار المكمل لها، والذى أضاف للآلية الخاصة بتطبيق

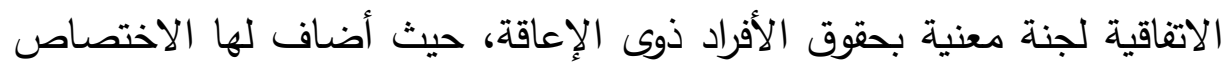

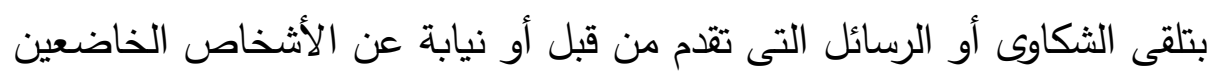

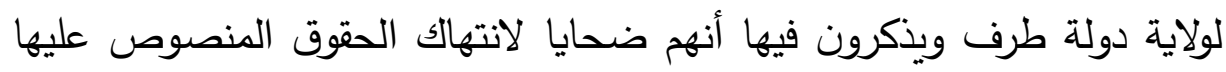
الاتفاقية. الاية دوله

وتعرف المادة ا الغرض من الاتفاقية بأنه تقوية وحماية وضمان التمتع

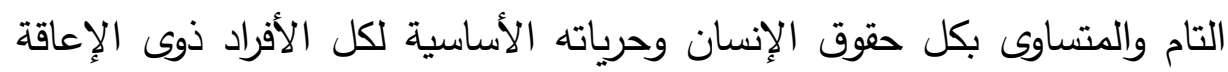

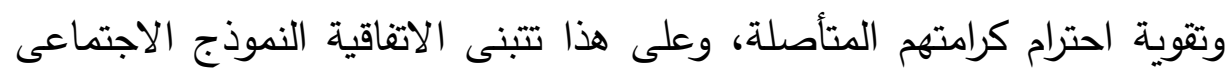
للإعاقة، وتعرف ذوى الإعاقة على أنهم هؤلاء الذين لديهم إعاقة بدنية أو عقلية

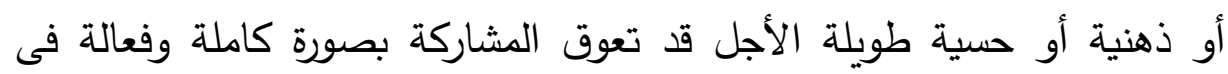

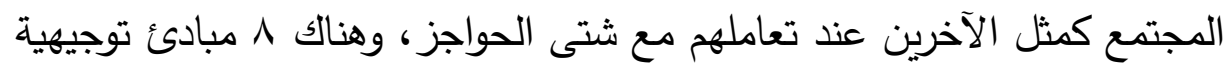

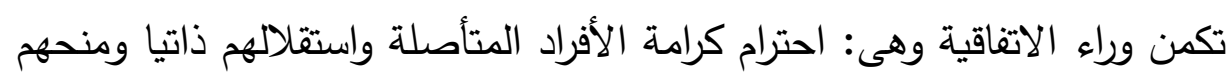

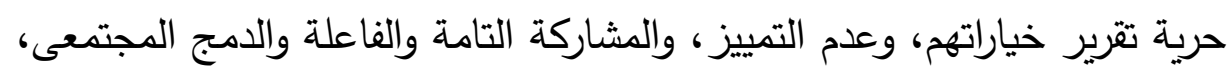

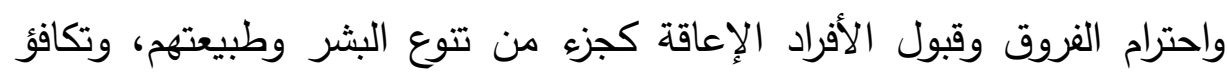

ro Clement Marumoagae, Disability Discrimination and the Right of

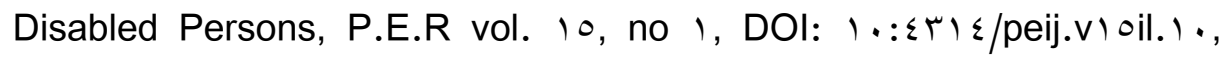
r. Tr, P. rol

بr اتفاقية حقوق الأشخاص ذوى الإعاقة اعتمدت بموجب قرار الجمعية العامة للأمم المتحدة

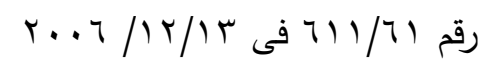

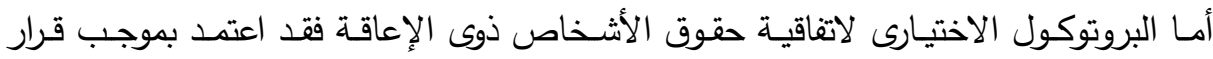

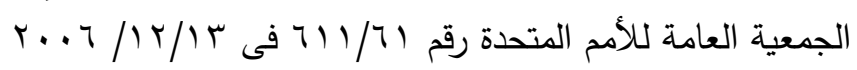

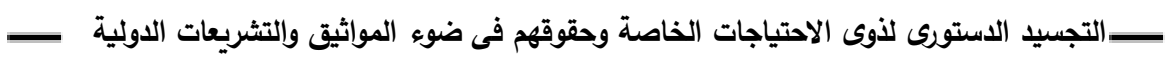

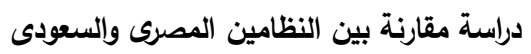


الفرص، وإمكانية الوصول، والمساواة بين الرجل والمرأة، واحترام القدرة المتطورة

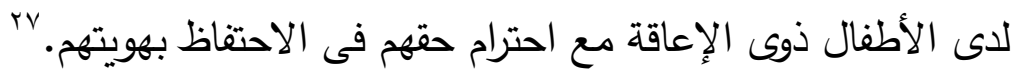

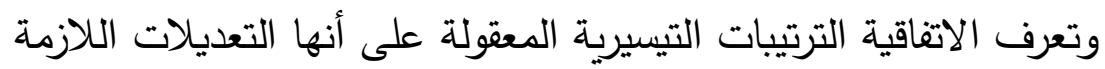

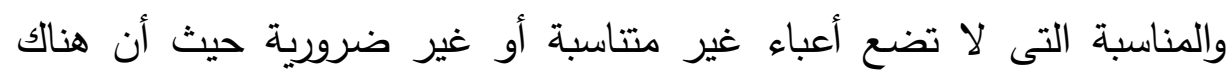

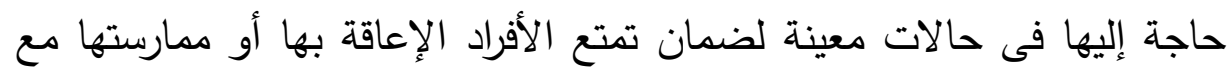

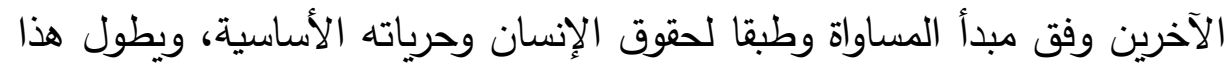

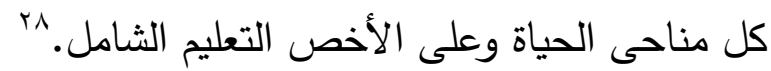
كما تؤكد المادة ^ من الاتفاقية على التوعية لأجل تقوية احترام الحقوق

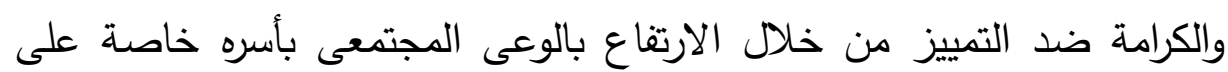

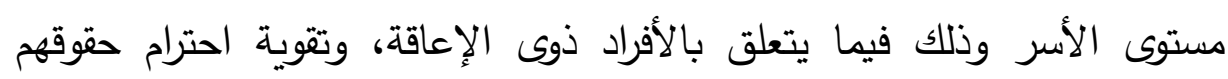

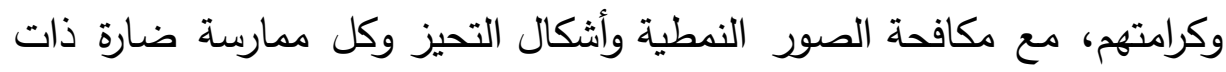
صلة بالأفراد ذوى الإعاقة كتلك التى تقوم على الجنس والسن فى كل مناحى الحياة، وكذلك تقوية الوعى بقدرة وإسهام الفرد ذى الإعاقة، كما أكدت الاتفاقية

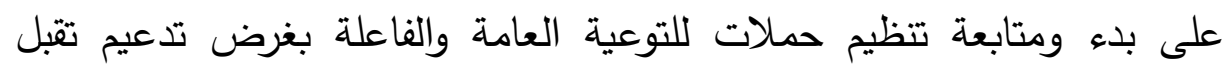

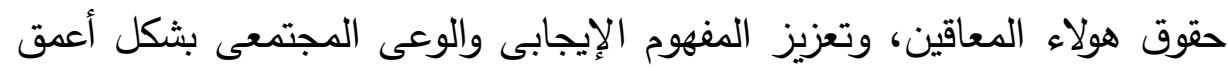

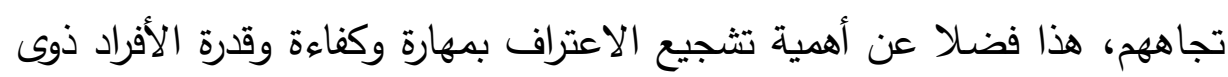

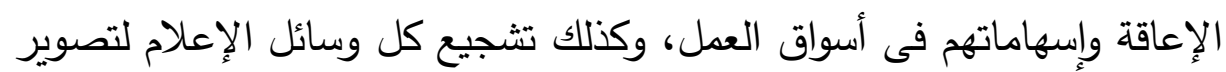
الأفراد ذوى الإعاقة بثكل يتفق مع الهدف من تلك الاتفاقية، وتدعيم برامج

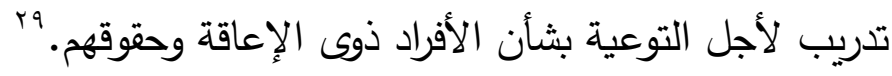

r Penelope Weller, The Convention on the Rights of Persons with Disabilities and the Social Model of Health: New Perspectives, DOI:

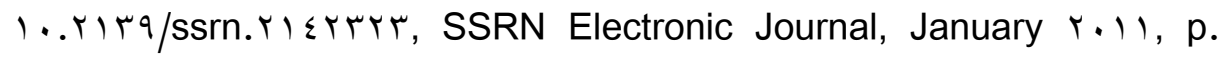
VI

^^ أندرو بيرنز وآخرون، من الاستبعاد إلى المساواة: إعمال حقوق الأشخاص ذوى الإعاقة،

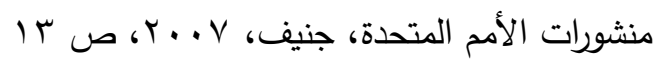

${ }^{r q}$ Harpur, Paul, and Richard A. Bales. The Positive Impact of the Convention on the Rights of Persons with Disabilities: A Case Study 
كما تئكد الاتفاقية على أن الأفراد ذوى الإعاقة يجب أن يكونوا قادرين

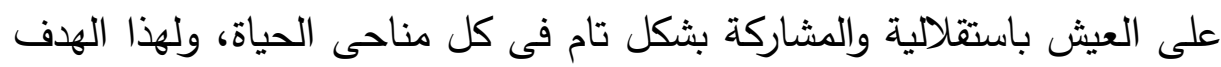

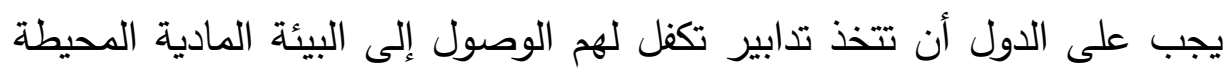

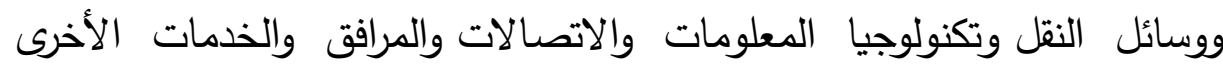
المتاحة المقدمة للجمهور ، ويمكن تصنيف الوصول إلى ب مجموعات رئيسية

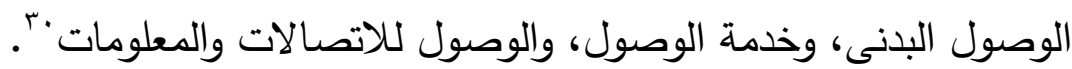

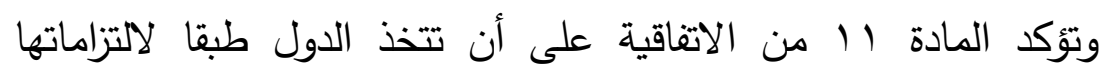

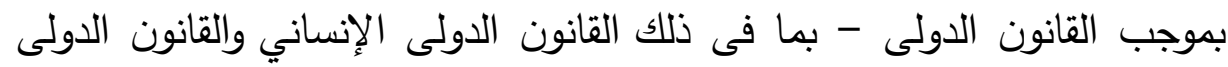

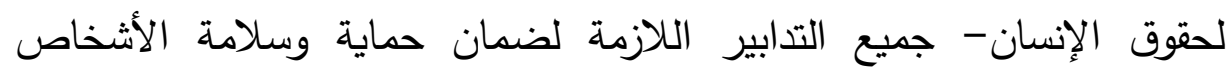
المعوقين فى حالات النزاع المسلح وحالات الطوارئ الإنسانية وحدوث كوارث طبيعية.

كما تؤكد المادة بأ من الاتفاقية الاعتراف بالسواسية أمام

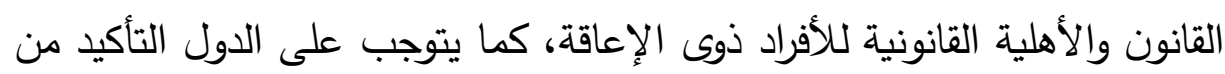
جديد أن لهم الحق فى الاعتراف بهم فى كل مكان كشخص أمام القانون، كما

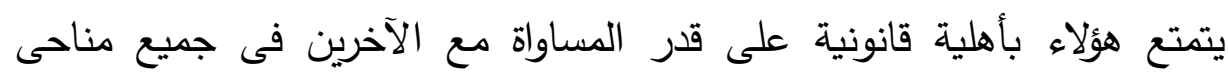

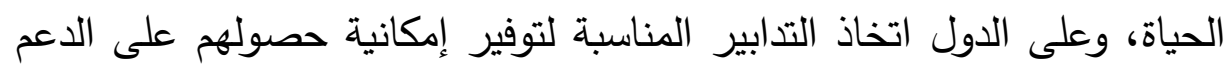

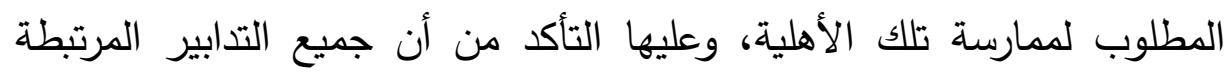

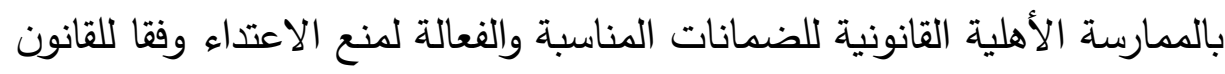

on the South Pacific and Lessons from the U.S. Experience. Northern Kentucky Law Review (rv) r., , P. Pr.

$r$ Lang, Raymond, Maria Kett, Nora Groce, and Jean-Francois Trani, Implementing the United Nations Convention on the rights of persons with disabilities: Principles, implications, practice and limitations.

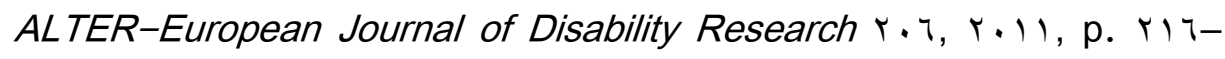
IV

"'Mégret, Frédéric. The Disabilities Convention: Toward a Holistic Concept of Rights, International Journal of Human Rights, ( $r$ ) $r .11$, p. YVI 
الدولى لحقوق الإنسان، وتكفل هذه الضمانات أن التدابير المرتبطة بممارسة تلك

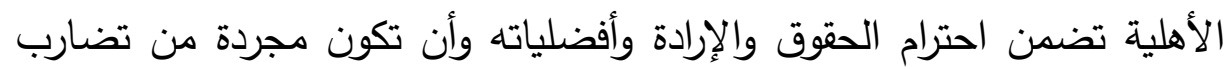

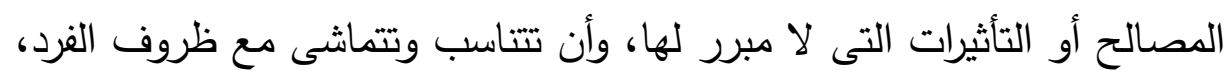

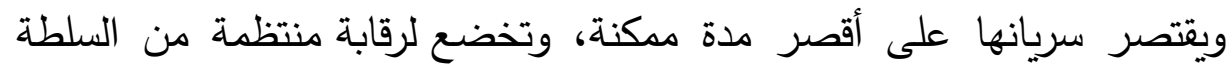

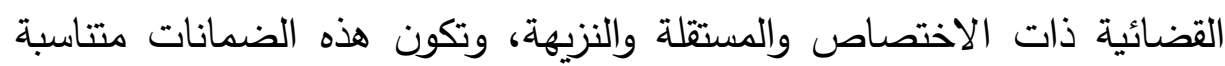

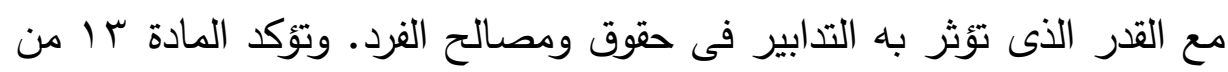

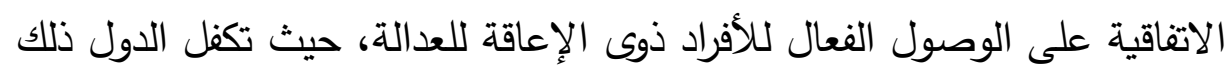

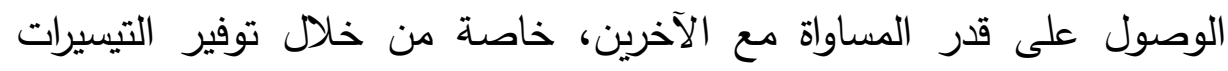
الإجرائية مع تسهيل دورهم الفعال فى المشاركة المباشرة وغير المباشرة كأن النقاهن

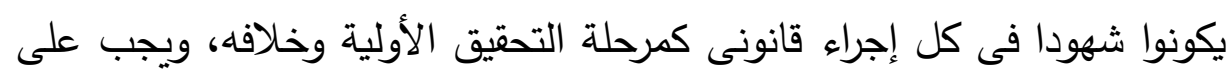

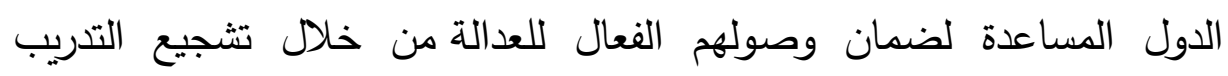
المناسب للعاملين فى مجال تحقيق العدالة مثل الشرطة وموظفى السجون،

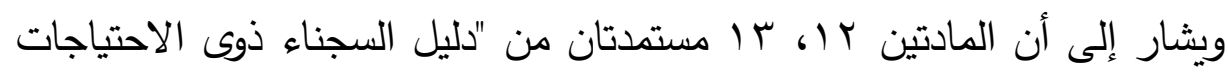

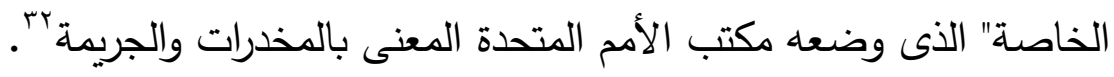

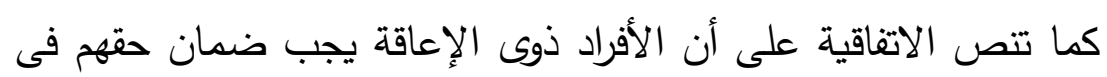

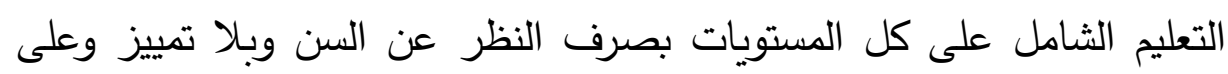
أساس تكافؤ الفرص، ولذا يجب ضمل ضمان عدم استبعاد الأطفال ذوى الإعاقة

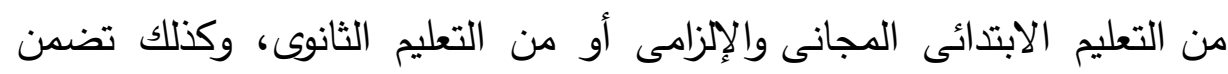

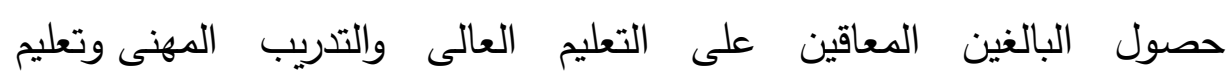
الكبار والتعلم مدى الحياة، وكذلك تسهيل حصولهم على الدعم المطلوب لأجل

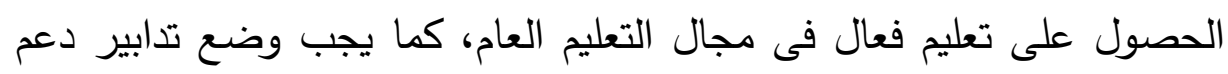

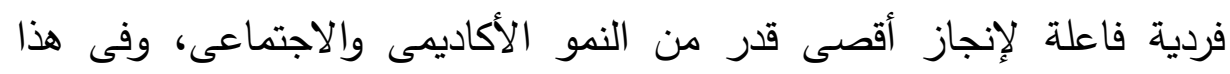
الإطار يجب على الدول اتخاذ تدابير مناسبة كالمصادقة على تعلم طريقة برايل وأنواع الكتابة البديلة المعززة ووسائط ووسائل وأثكال الاتصال ومهارات التوجيه

זr أندرو بيرنز وآخرون، من الاستبعاد إلى المساواة: إعمال حقوق الأشخاص ذوى الإعاقة،

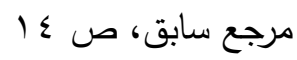
I Trq

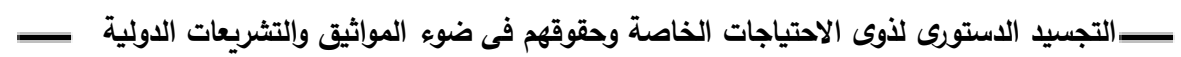

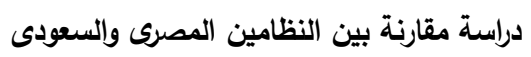


والتتقل وتيسير الدعم والتوجيه بواسطة الأقران، ودعم تعلم لغة الإشارة وتثجيع

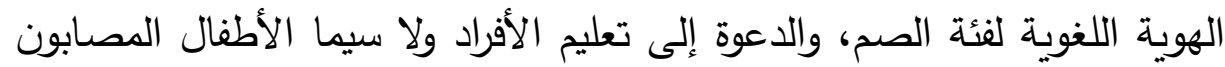

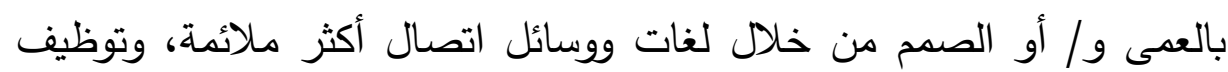

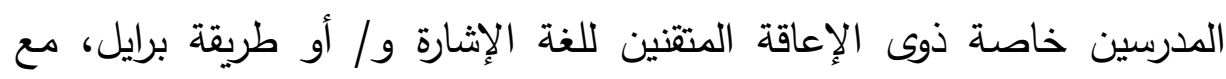

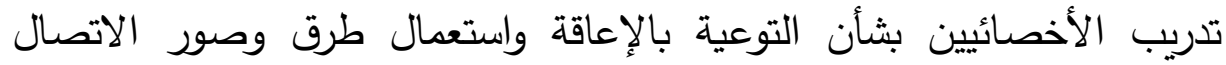

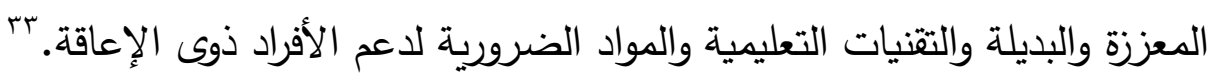

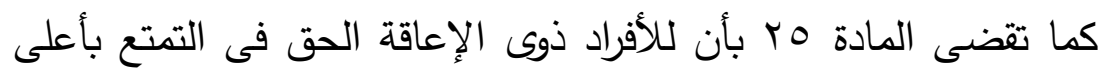

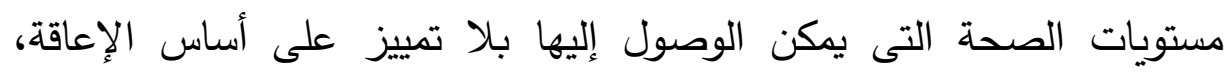

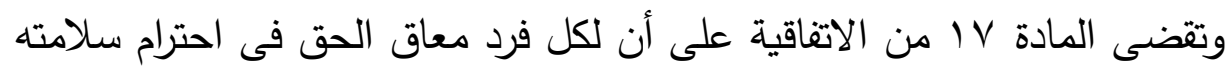

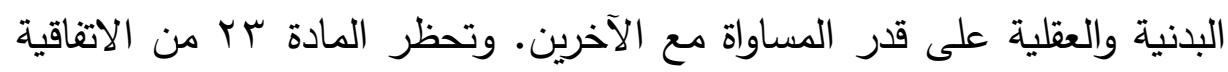

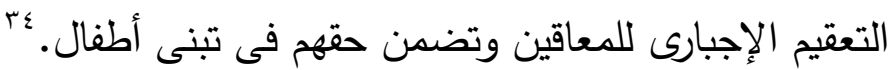

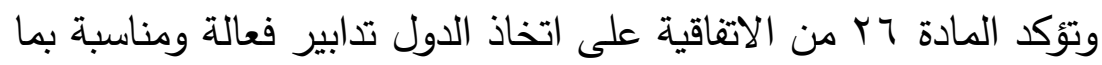

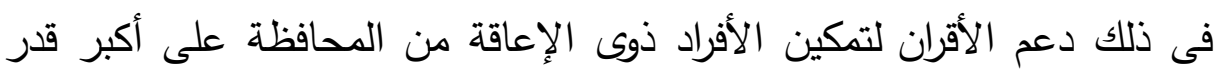

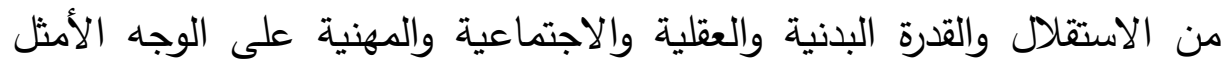
وكفالة اشتراكهم بشكل كامل فى كل مناحى الحياة ولتحقيق هذه الغاية تقوم الدول

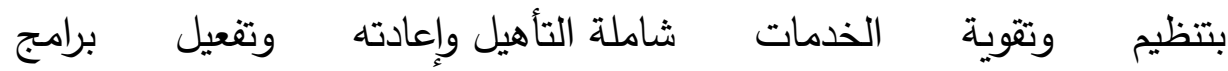
الصحة والعمل والتعليم والخدمة الاجتماعية، على أن تبدأ تلك الخدمات والبرامج

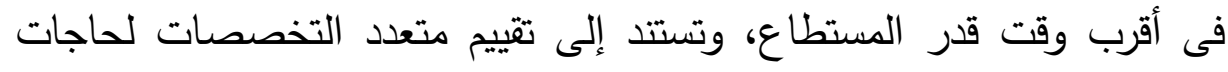

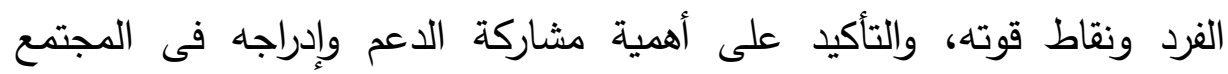
المحلى، مع ضرورة توفير ذلك للأفراد ذوى الإعاقة فى أقرب مكان ممكن لهم

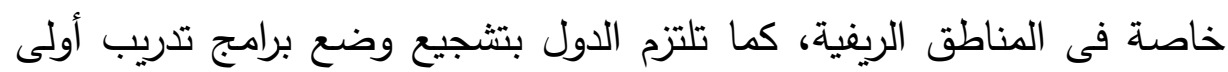

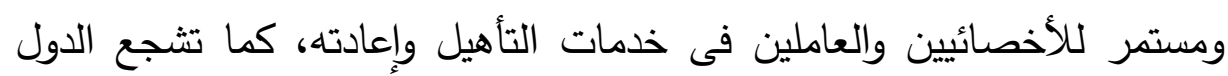

${ }^{r}$ Penelope Weller, The Convention on the Rights of Persons with Disabilities and the Social Model of Health: op, cit., p. Ar

${ }^{r}$ Harpur, Paul, and Richard A. Bales. The Positive Impact of the Convention on the Rights of Persons with Disabilities, op. cit., p. rN I

Ir.

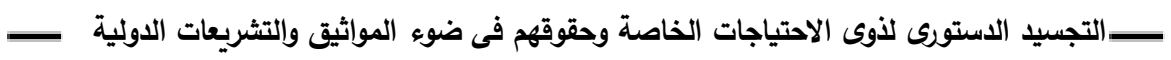

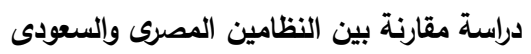


توفير الأجهزة والتقنيات المعينة التى تصمم للأفراد ذوى الإعاقة وفق صلة تلك

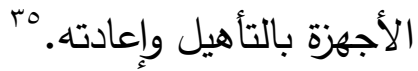
وتعترف الاتفاقية بأن الإعاقة تقع بسبب التفاعل بين الأفراد المصابين

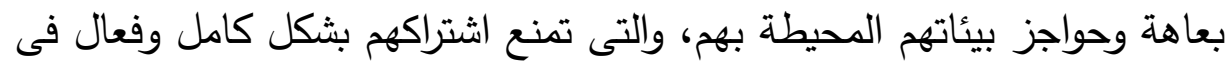
المجتمع على قدر المساواة مع الآخرين، وتعترف كذلك بأن المعاقين مستمرون تهن

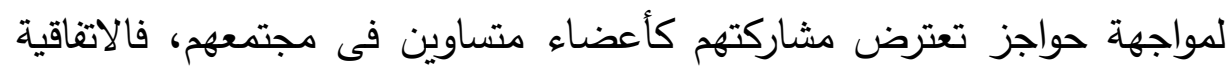
تكرس حق المعوقين فى المشاركة التامة وعلى قدر المساواة فى المجتمع والتعليم

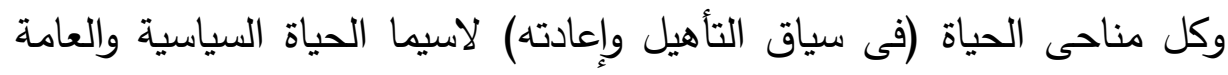
والثقافية والترفيهية والرياضية، لذا يجب على الدياه الدول اتخاذ التدابير المناسبة كتمكين المعاق من أن نتاح لله فرصة لتنمية واستغلال إمكاناته الإبداعية

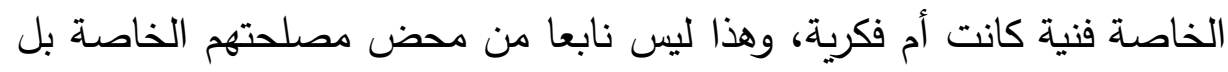

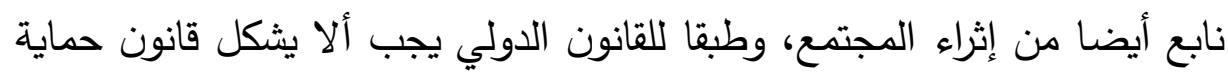

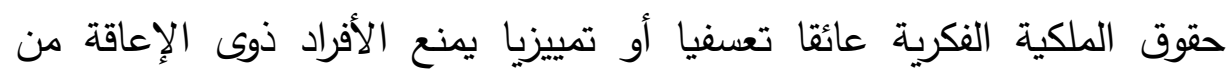

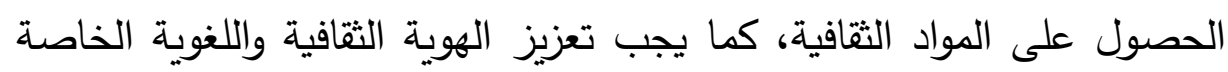

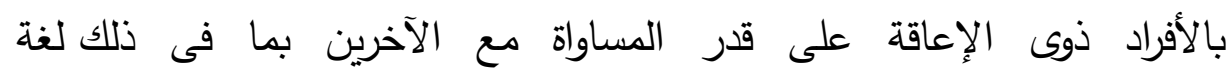

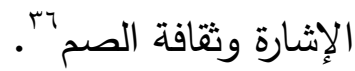

وتشترط المادة rV أن الدول بحق الأشخاص ذوى الإعاقة فى العمل

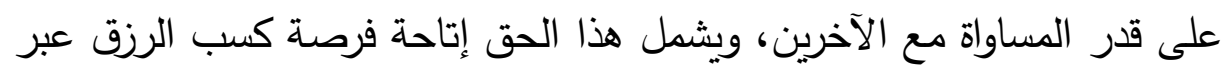
تشغيل من اختيارهم أو يقبلونه بحرية فى سوق العمل عبر بيئة عمل مفتوحة

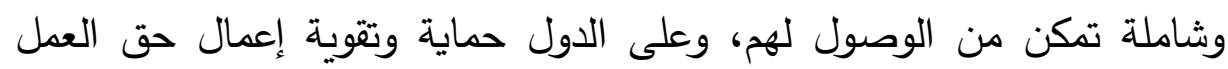
حتى لأولئك الذين تحدث لهم الإعاقة خلال العمل وذلك من خلال أخذ خطوات

ro Lang, Raymond, Implementing the United Nations Convention on the rights of persons with disabilities, op, cit., $Y \backslash V$

${ }^{r}$ Gupta, Shivani, Meenakshi Balasubramaniam, Sudha Ramamoorthy, Rama Chari, and Bhargavi Davar. Monitoring Report of Civil Society, United Nations Convention on Rights of Persons with DisabilitiesIndia. r. I r, p. Vฯ 
مناسبة كسن دساتير وقوانين تحظر التمييز على أساس الإعاقة وكذلك فيما

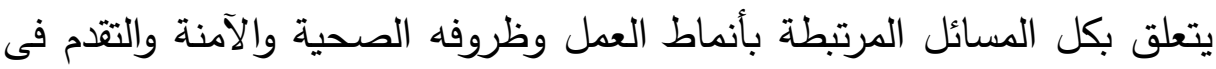
الوظيفة، وحماية حق ذى الإعاقة على قدر المساواة مع الآخرين فى تكافؤ

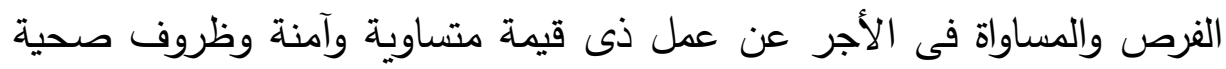
شاملا الحماية من التحرش والانتصاف للمظالم، كما تكفل الدولة للأفراد ذوى

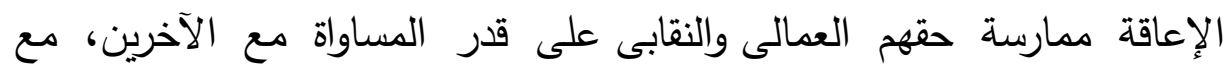

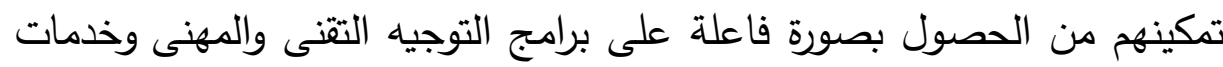

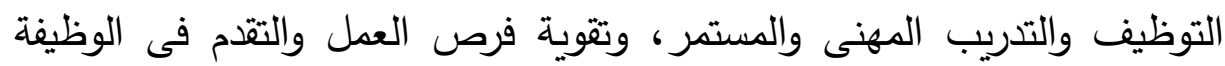

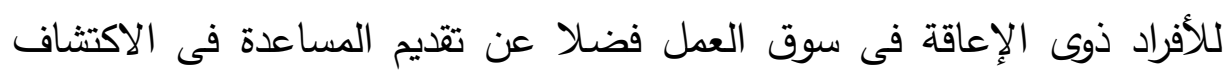
والحصول عليه والمداومة عليه والعودة للعمل، وتقوية فرص العمل العمل الحر وريادة الأعمال وتطوير الأعمال التعاونية، وضمان توفير الترتيب التيسيرية المعقول للأفراد ذوى الإعاقة فى مكان العمل، وتشجيع اكتسابهم للخبرة المهنية فى أسواق العمل المفتوحة، وتقوية برامج إعادة التأهيل المهنى والوظيفى والإنى الاحتيفاظ

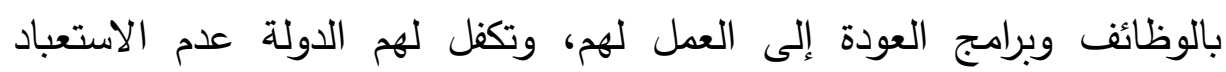

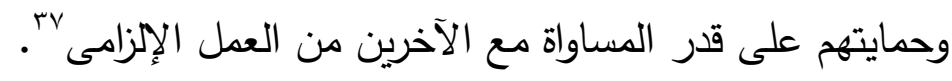

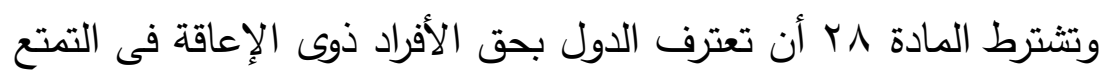
بمستوى معيشى لائق لهم ولأسرهم وتوفير ما يفى باحتياجاتهم الغذائية والكسائية

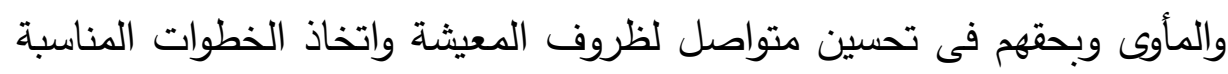

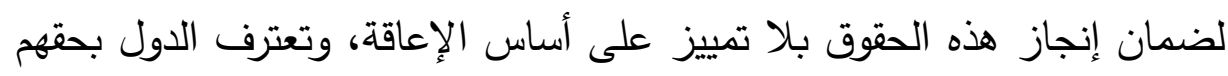

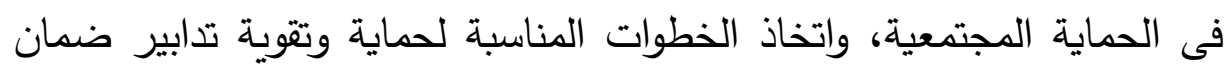
المساواة فى إمكانية حصولهم على خدمات المياه وضمان الوصول إلى الخدمة المناسبة وبأسعار معقولة لتلبية الاحتياج المرتبط بالإعاقة، وكذلك ضمان فان

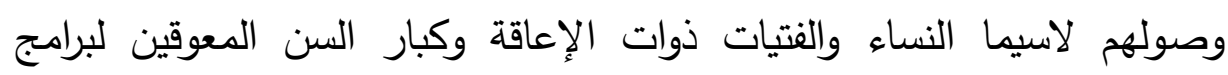

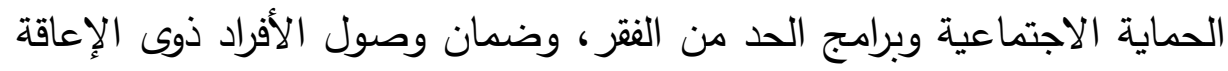

rv أندرو بيرنز وآخرون، من الاستبعاد إلى المساواة: إعمال حقوق الأشخاص ذوى الإعاقة،

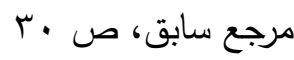
I TrY

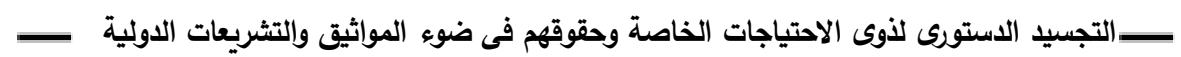

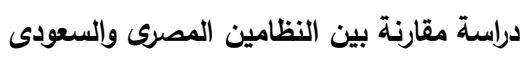


وأسرهم الذين يعيشون فى حالة الفقر للمساعدات التى تقدمها الدولة لتغطية

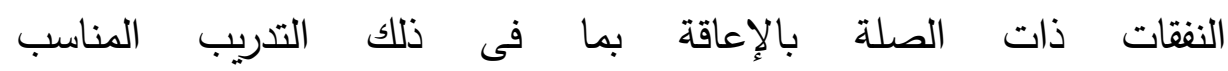

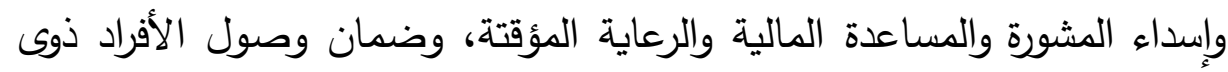

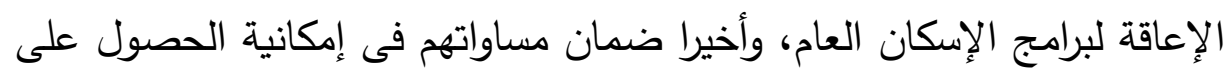

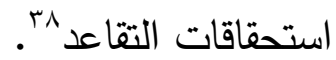

وتشترط المادة و ج على كل الدول حماية حق الأفراد ذوى الإعاقة فى

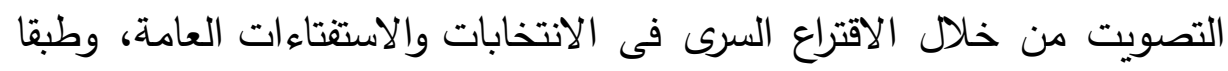
لهذا الحكم فإن على كل الدول التزام بتوفير معدات التصويت التى تمكن التصن

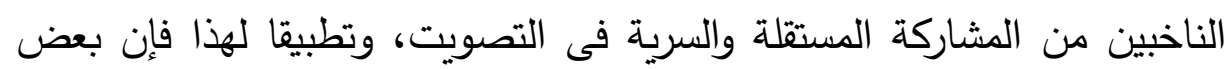

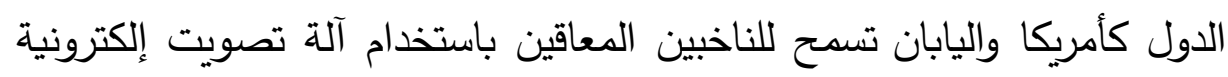

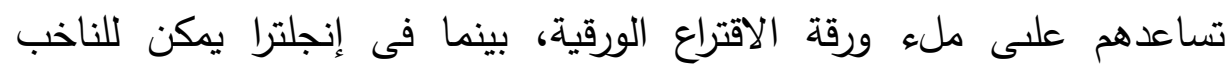
ضعيف البصر استخدام صوته فى الاقتراع بلغة برايل، لكن أغلب الدول تسمح

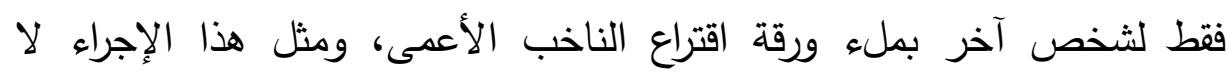

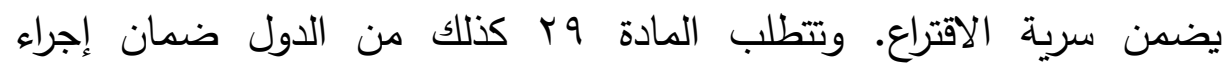
التصويت ومواده بصورة مناسبة ووسهلة الفهم والاستخدام، ففى أمريكا والسويد

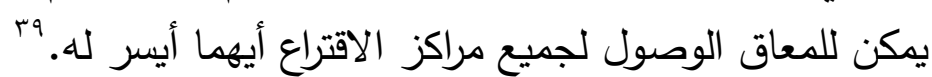

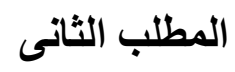

تجسيد ذوى الاحتياجات الخاصة وحقوقهم فى بعض التثريعات

ا ـ الولايات المتحدة الأمريكية

أصدرت أمريكا قانون المعاقين الأمريكيين فى عام ، 99 الأهريه والذى يضمن

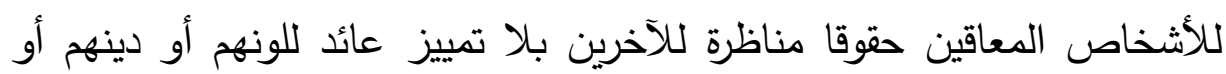
سنهم أو نوعهم أو منشأهم، ويضمن للمعاقين حقوقا متكافئة مع حقوق الأسوياء

${ }^{\wedge \wedge}$ Degener, Theresia. Disability in a Human Rights Context. Laws ( $(0)$ (ro), r. I T, p. 70

${ }^{r q}$ Penelope Weller, The Convention on the Rights of Persons with Disabilities and the Social Model of Health: op, cit., p. 10 
فى العيش والعمل والنقل والاتصالات والخدمات الحكومية الفيدرالية منها أو ما

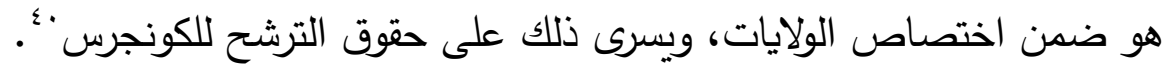

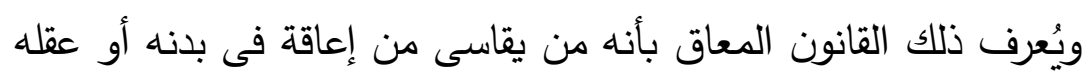

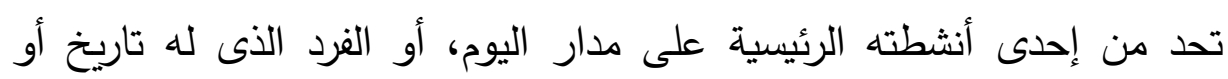

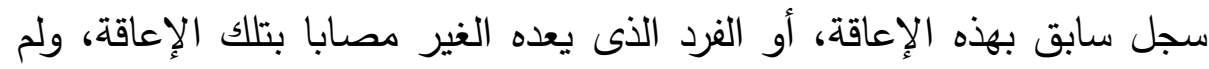

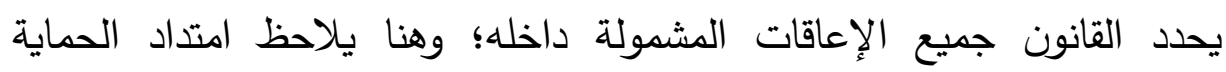

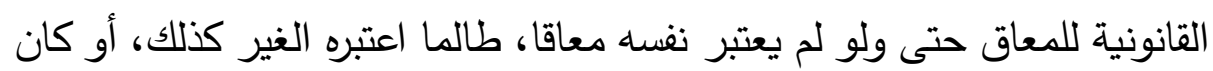

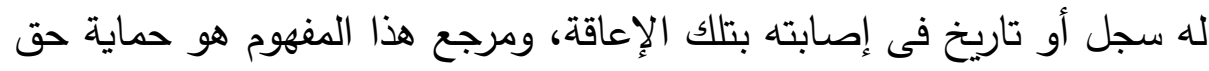

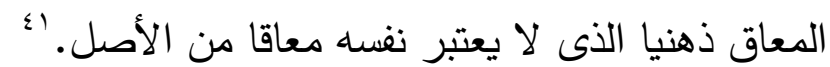

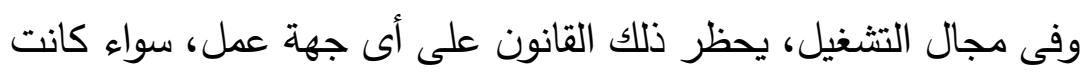
هيئات حكومية أم شركات خاصة، التمييز ضد الفرد المعاق إذا كانت لديه المؤهلات المطلوبة لشغل الوظيفة، ويسرى ذلك على إجراء وطلب الترشح

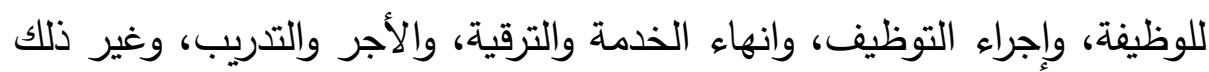

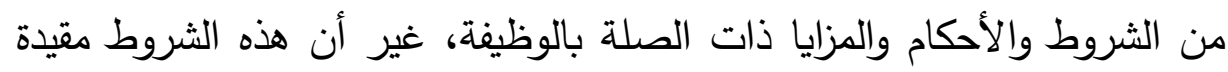
بألا يقل عدد موظفى الشركة عن 10 موظف. ويلزم القانون الثركات باتخاذ الترتيبات الملائمة للموظف المعاق كتعديل مواعيد عمله، أو إعادة هيكلة وظيفته، أو نقله إلى وظيفة خالية تناسب قدرته، أو تزويده بالوسائل المعاونة

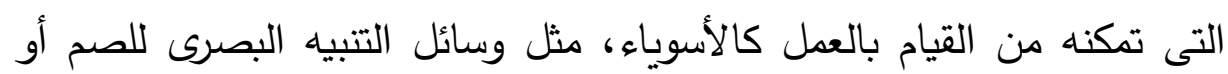
البرامج الناطقة للمكفوف أو أجهزة التواصل عبر الإنترنت للبكم، وخلافلافه مئه ويحظر القانون ممارسة أى تمييز ضد الموظف المعاق فى النشاط الترفيهى ومزايا

¿. O'Brien, Ruth. Crippled Justice: The History of Modern Disability Policy in the Workplace, University Of Chicago Press, Y.. I, P. 00 \& Colker, Ruth and Milani, Adam. Everyday Law for Individuals with Disabilities, Paradigm Publishers, Y... , p. 10 
التأمين الصحى ووسائل الانتقال، ويحظر القانون أى استعلام عن إعاقة المتقدم

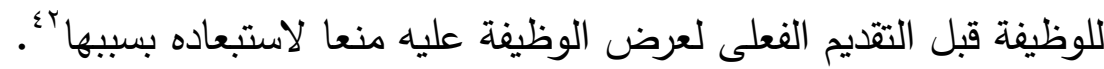

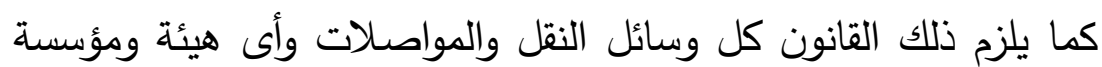
حكومية أو خاصة، وكل فندق وشركة وكلية وجامعة ومدرسة خاصة وعيادة

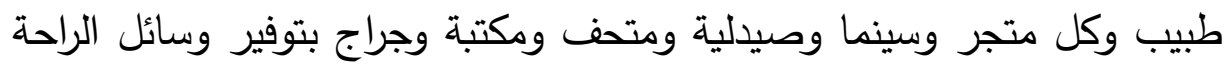

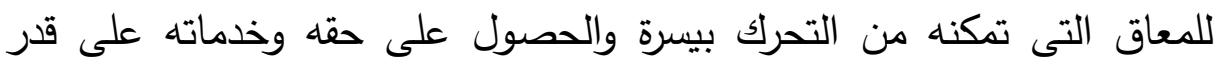

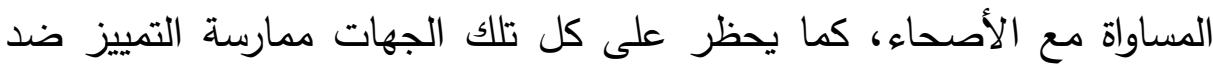
المعاق بأى شكل من الأشكال، ويستثى من ذلك النوادى الخاصة والمؤسسات

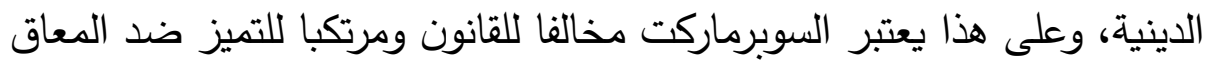

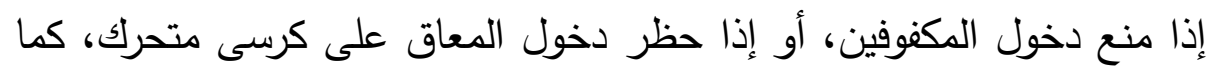

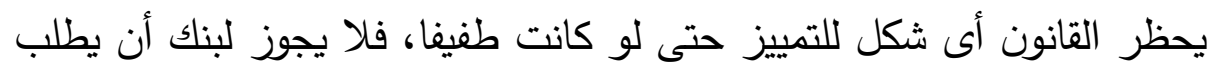

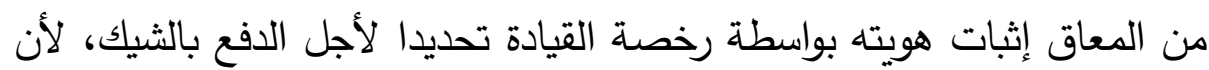
هذا يعد جريمة تمييز ضد ضعيف البصر ، لاسيما إذا كان غير مؤهل للحصول

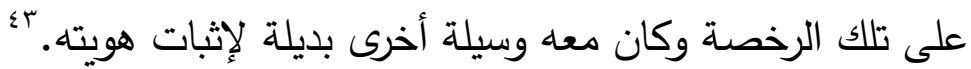

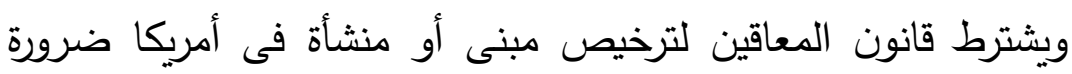

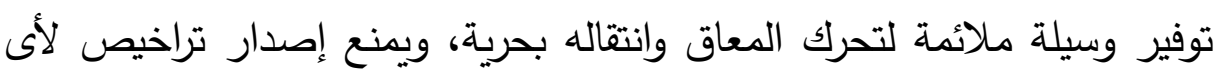

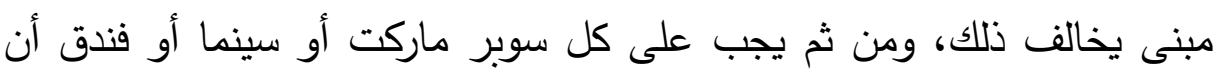

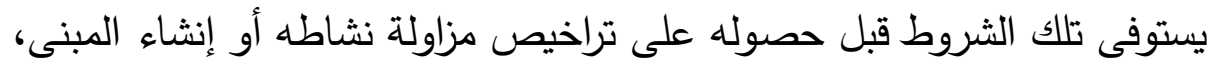

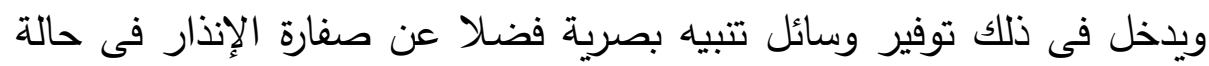

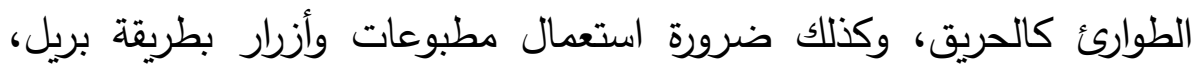

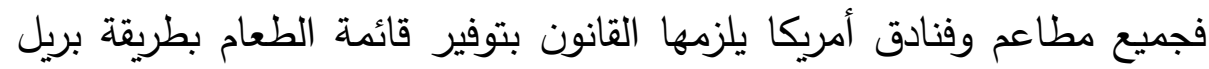

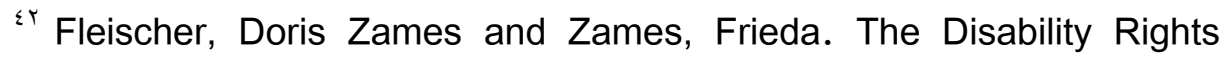
Movement: From Charity to Confrontation, Temple University Press, rnd Edition, r. Il, p. qr

${ }^{\& r}$ Longmore, Paul, K. and Umansky, Laurie, editors, The New Disability History: American Perspectives, New York University Press, r..., p. |r| 
للنزيل المكفوف، ونفس الأمر مع البنك الملزم بتوفير آلة صرافة بأزرار تحتوى

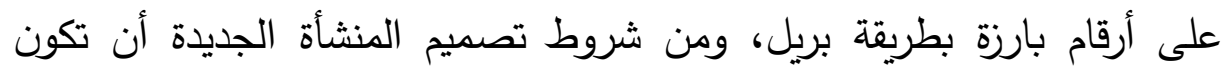

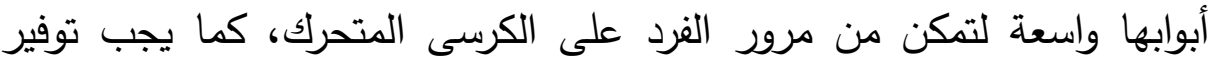

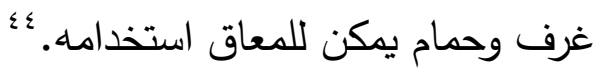
ويلزم القانون الجامعة فى أمريكا بأن توفر وسيلة انتقال للمكفوف الفئه

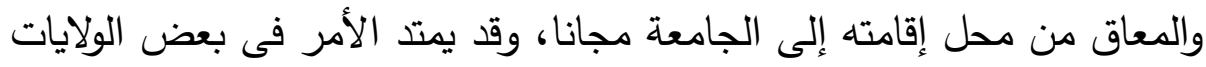

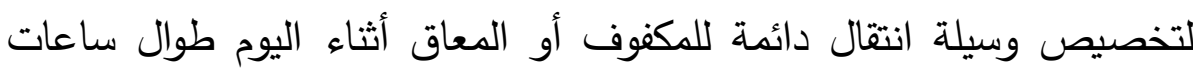
دراسته ؛؛

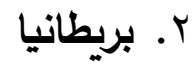

فى عام • 1 • ب صدر قانون المساواة البربطانى الذى ألغى كل أصناف التمييز بين مواطنى الدولة على أساس جنسى أو عرقى أو عقائدى أو الإعاقة أو أونى

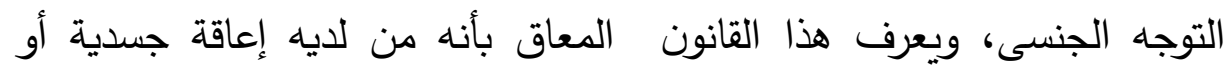
عقلية، وكان لتلك الإعاقة تأثير سلبي كبير وطويل الأجل على قدرته على القيام بنشاطات طبيعية ويومية، كما ينص هذا القانون على المساواة بين مواطنى الدولة وعدم التمييز بينهم بسبب الإعاقة، ويلزم الدولة ومؤسساتها وشركاتها

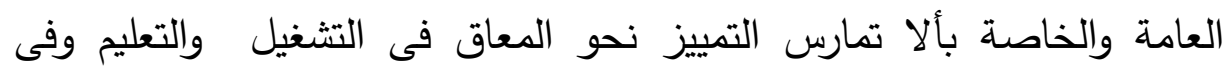

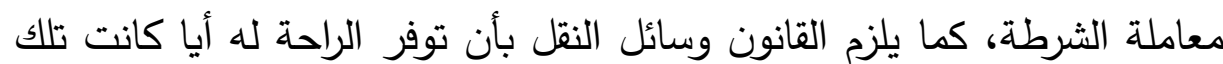

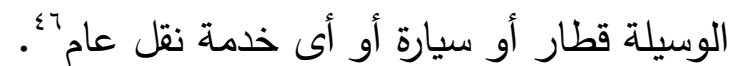

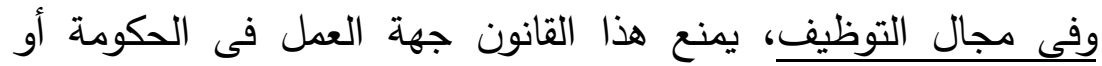

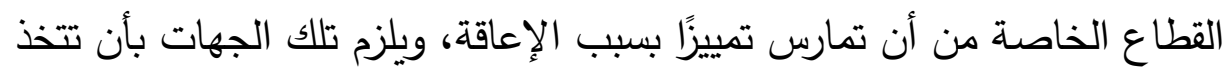

¿ O'Brien, Ruth. Crippled Justice: The History of Modern Disability Policy in the Workplace, op, cit, P. ir

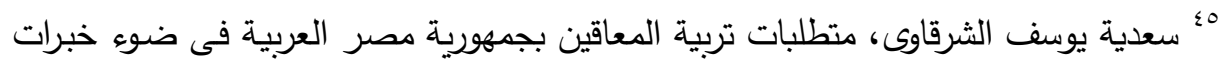

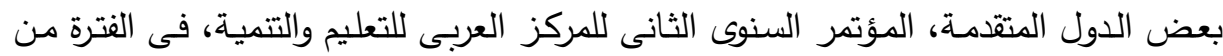

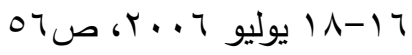

"House of Lords Library Briefing, Disability in the UK: Rights and Policy Debate, report June r.।^, p. । 


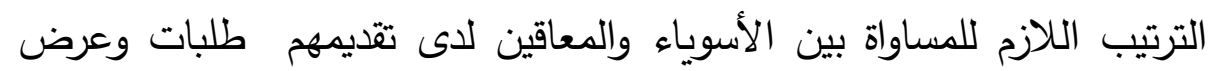

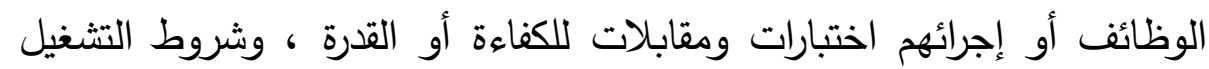
والترقيات والأجور والنقل وفرصة التدريب وحالات إنهاء الخدمة والتأديب والثكوى، وتلتزم جهة العمل فى حال ما إذا كان المعاق يجلس ولى ولى كرسيه

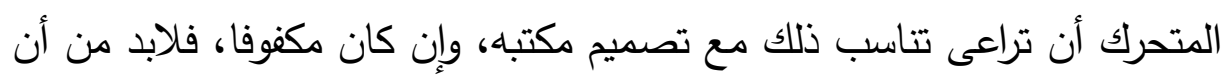

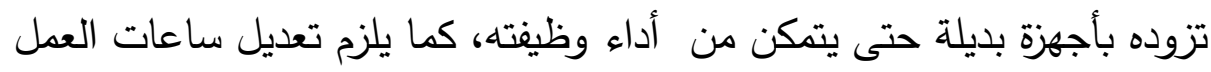

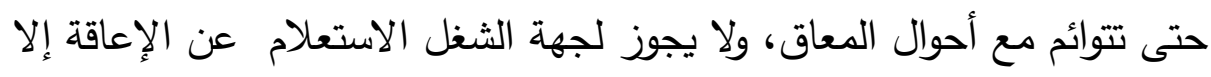

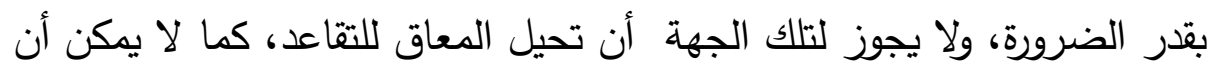
تستغنى عنه لمحض كونه معاق، فاختيار العمالة الزائدة تتم بشكل عادل ونزيهة

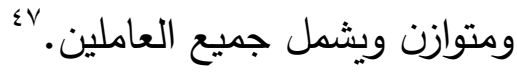

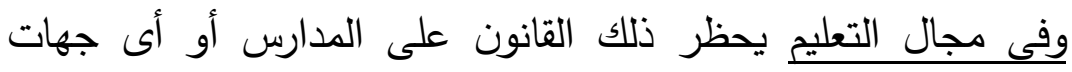

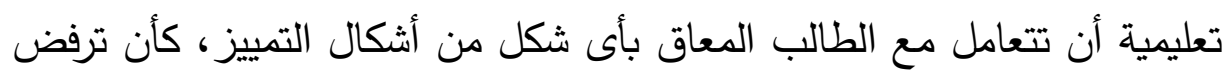

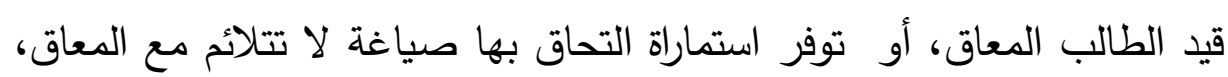

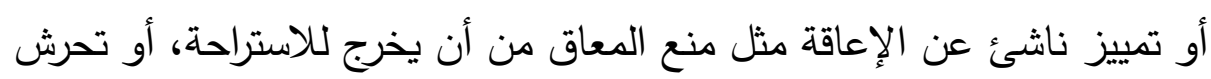

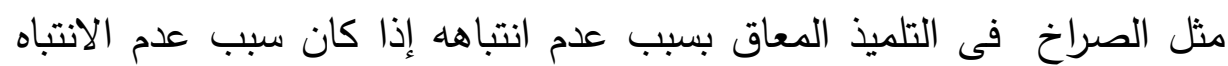

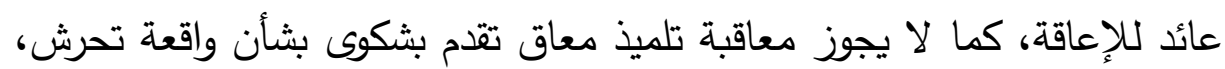

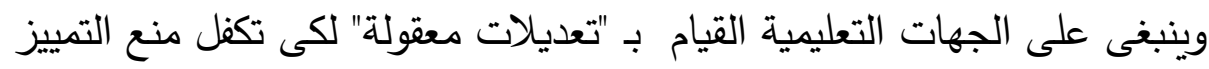

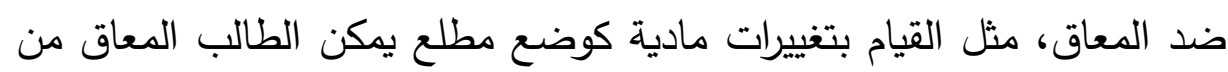

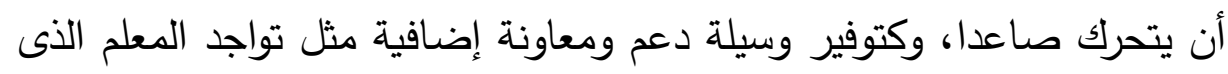

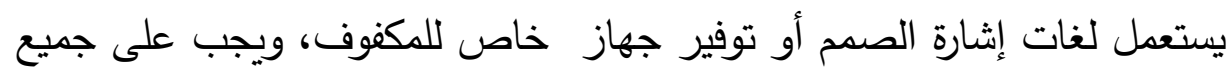

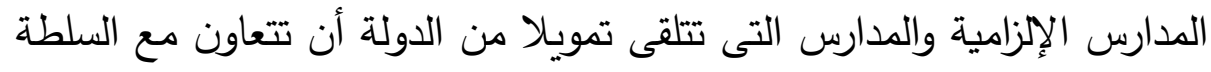

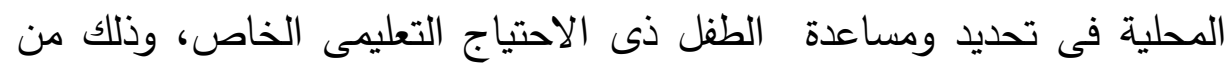

${ }^{\varepsilon v}$ Dorothy Estrada-Tanck, Human Rights of Persons with Disabilities in International and EU Law, op, cit., p. $\leq o$ 
خلال خطة فى السنة الثالثة الإعدادية حتى يمكن تحديد الدعم الذى يحصل

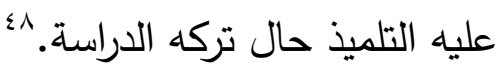
ويتمتع المعاق بحقوق لاى استجوابه أو التحقيق معهد، كأن توفر لله

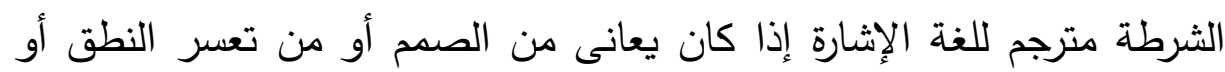

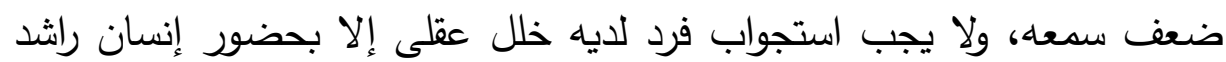

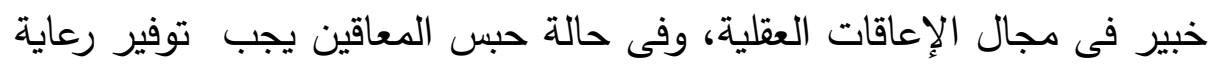
طبية تلائم ظروفه.

ويلزم ذلك القانون الحكومة بأن تصدر لائحة تتظيمية لتيسر استعمال المعاق لجميع وسائل النقل من سيارات أجرة لقطار وخلافه، ومن ثم تلزم الدولة لتصن

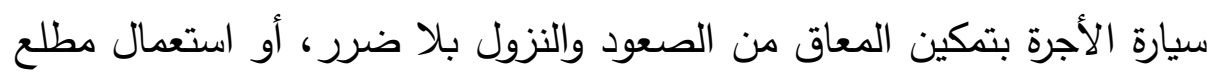

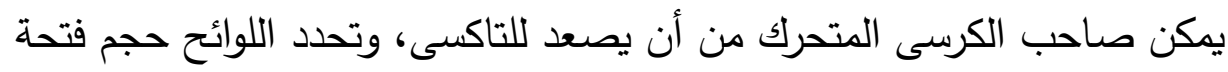
الباب واتساع مقصورة ركاب سيارة الأجرة وأدوات تجهيزها التى تقوم بتثبيت الكرسى المتحرك خلال تحرك التاكسى، ويعتبر سائق التاكسى مخالفا للقانون

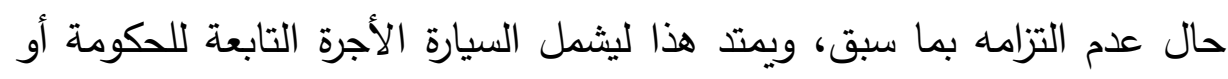
للقطاع الخاص، بل يشمل كل أتوبيس وقطار سكة الحديد ومترو الأنفاق. • r. الند

يضمن دستور الهند بموجب الفصل الثالث حقوق الإنسان الأساسية

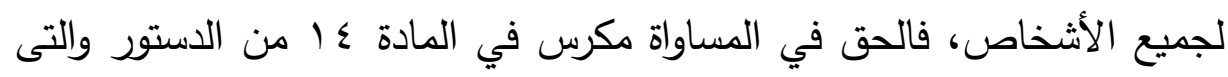

¿A Blanck B, Wilichowski A and Schmeling J, 'Disability Civil Rights Law and Policy, William \& Mary Bill of Rights Journal, $Y(r)(r \ldots \varepsilon) p$. rAV

«9 J Beqiraj, L McNamara and V Wicks, Access to justice for persons with disabilities: From international principles to practice, International Bar Association, October r. $\vee \vee, p . ~ r q$

- Inclusion Scotland, Disability Rights UK and Disability Wales, Implementation of the United Nations Convention on the Rights of Persons with Disabilities Alternative report - Great Britain, January r. Y V, p. ro 
تقر بأن جميع الأثخاص متساوون أمام القانون، ويحق للأشخاص ذوي الإعاقة الحصول على هذا الضمان بعدم التمييز ضدهم بأي شكل من الأنسان الثكال

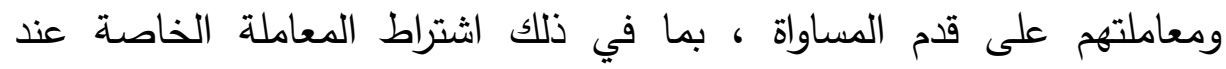

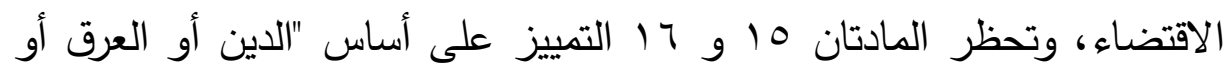
الطبقة أو الجنس أو مكان الميلاد أو أي منهما ، وتكفل تكافؤ الفرص في مسائل

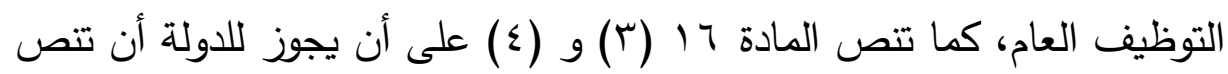

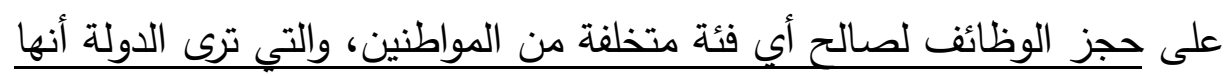

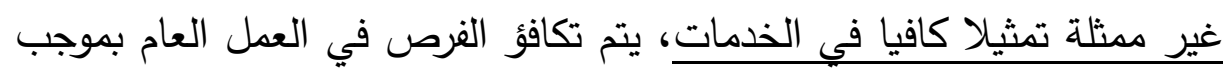
قانون الأشخاص ذوي الإعاقة ، وقد تم دعم الحق في المساواة للأشخاص ذأدوي

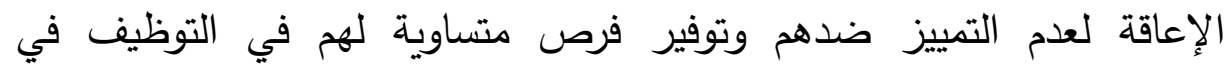

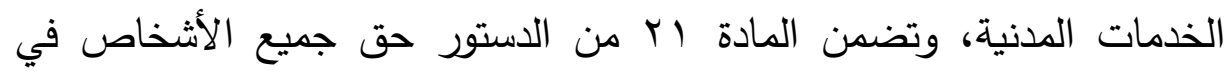
الحياة ، والذي فسرته المحكمة العليا على أنه يشمل الحق في العيش بكرامة ،

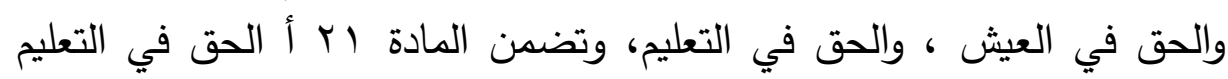

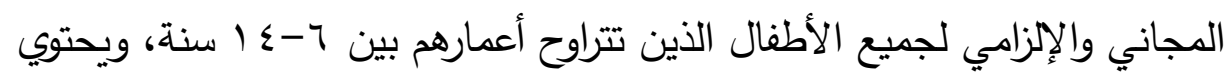

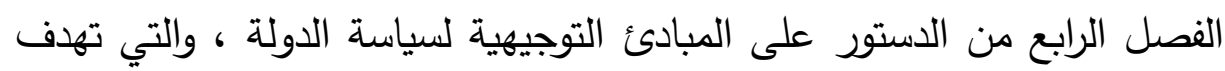

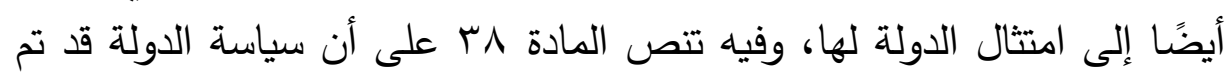
توجيهها للتقليل إلى أدنى حد من التفاوتات، وتأمين الحق في سبل عيش ملأل ملائمة،

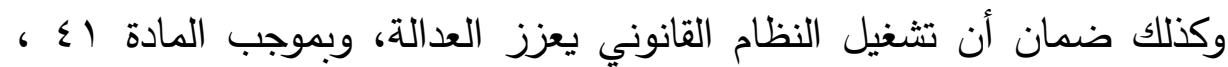

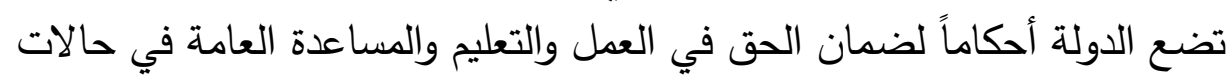
البطالة والثيخوخة والمرض والعجز وغيرها، كما تسعى الدولة إلى توفير التعليم

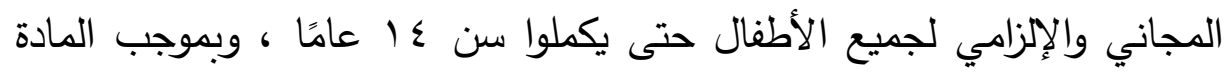

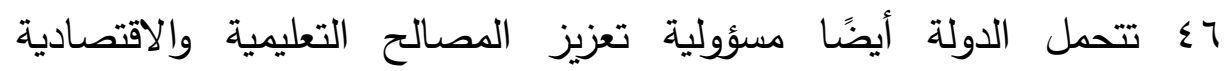
للقطاعات الأضعف من الشعب برعاية خاصة، تسري جميع هذه الأحكام على

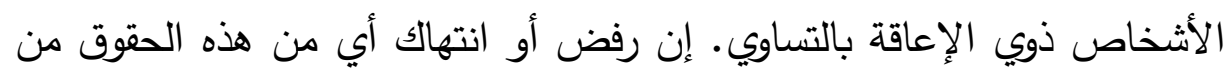
شأنه أن يمنح أي شخص الحق ذإعة في الاتصال بالمحاكم العليا أو المحكمة العليا 
في ولاياتها القضائية بموجب المادتين بrr و rr ، ، على التوالي ، في حالة

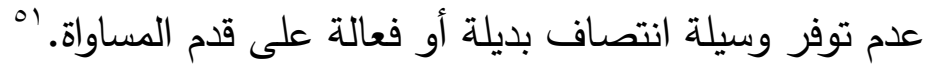

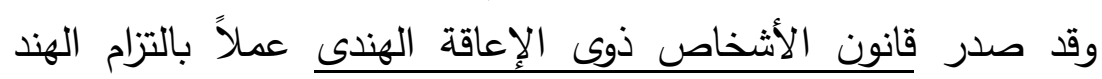

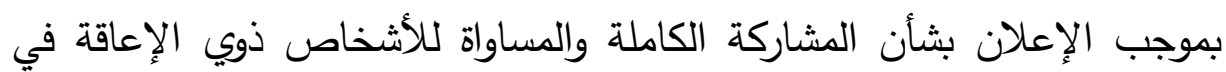

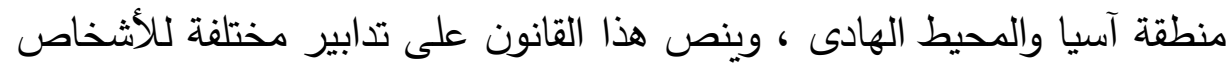
ذوي الإعاقة لتسهيل حصولهج على التعليم والعمل والبنية التحتية الأساسية

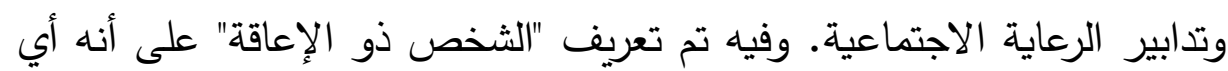

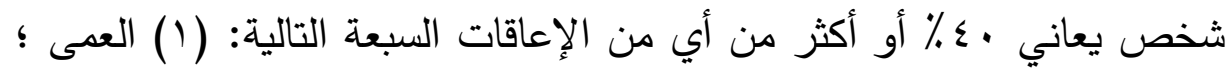

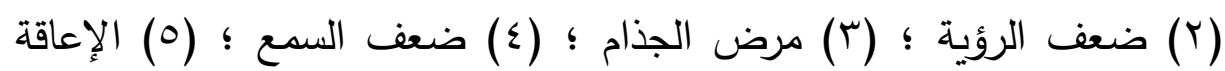

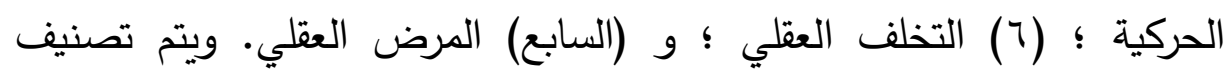
الأشخاص الذين يندرجون ضمن هذا التعريف على أنهم يعانون من خلل ،

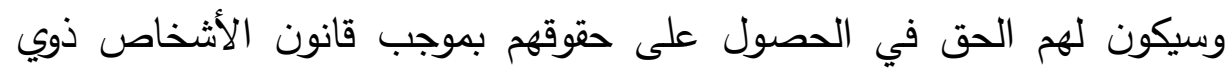
الإعاقة. والحقوق الرئيسية المتاحة للأشخاص ذوبي الإعاقة هي في في مجال التعليم

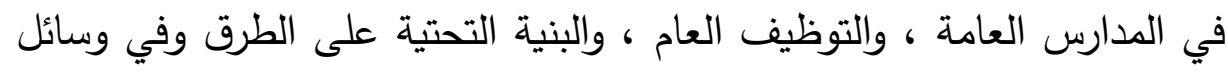
النقل العام والوصول للمباني العامة، فضلا عن تدابير إصلاملاحية لعماية حقوقهم.

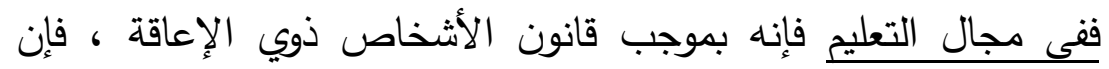

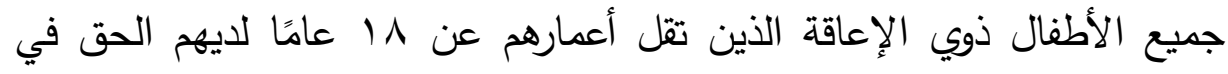
التعليم المجاني والإلزامي المتاح، وهذا يتجاوز ولاية قانون حق الأطعائ الطفال الأسوياء

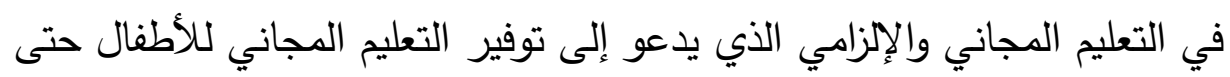

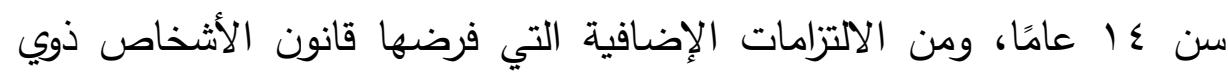

- Kalpana Kannibiran, Monitoring the Human Rights of Persons with Disabilities: Laws, Policies and Programs in India, Disability Rights Promotion International (D.R.P.I.) Y.. q, p. $\varepsilon$

${ }^{\circ}$ ChoudharyLaxmi Narayan, Thomas John, The Rights of Persons with Disabilities Act, Does it address the needs of the persons with mental illness and their families,

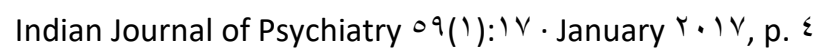


الإعاقة على الحكومة - فيما يتعلق بالتعليم الرسمي - ضرورة بذل الجهود

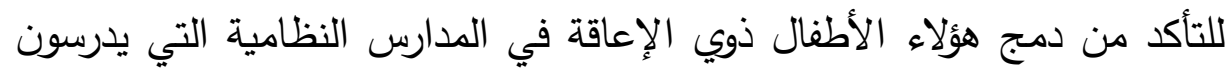

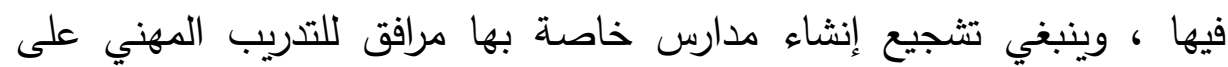

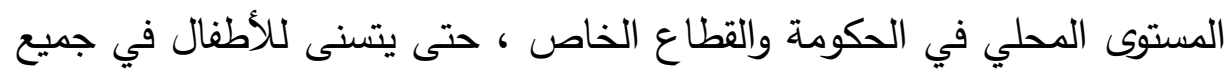

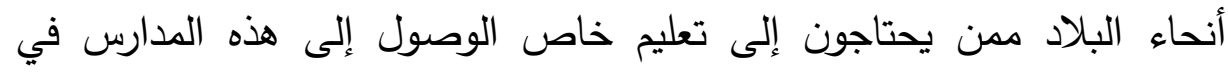

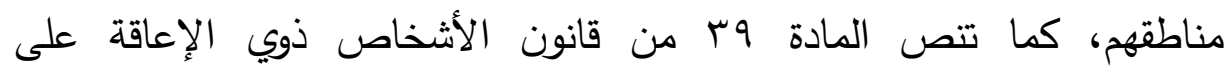
تخصيص ץ\% من جميع المقاعد في المؤسسات التعليمية التي تدعمها الحكومة التصن

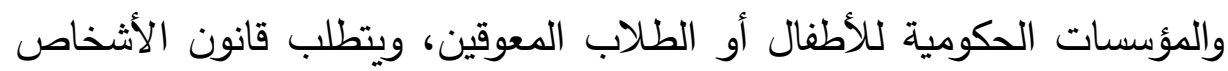
ذوي الإعاقة أيضًا من الحكومة وضع وتتفيذ خطط تتعلق بالتعليم الوظيفي غير

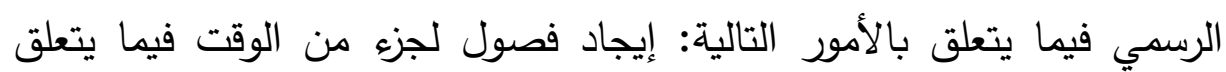

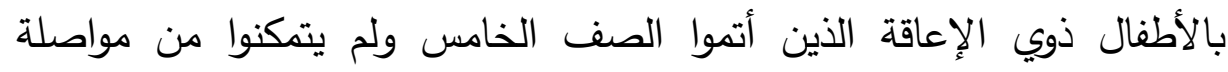
الدراسات بدوام كامل بعد ذلك ؛ وإيجاد فصول خاصة لجزء من الوقت لتوالت لتوفير

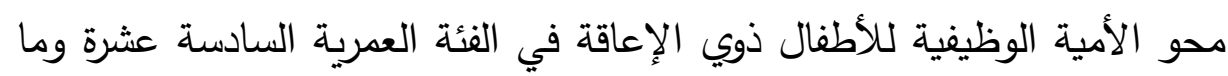
فوق ؛ وتوفير التعليم غير الرسمي بعد توجيه مناسب ؛ وتيسير تعليمهم من

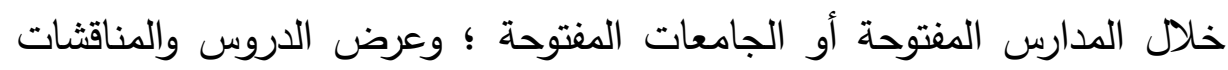

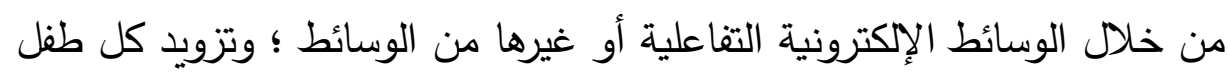

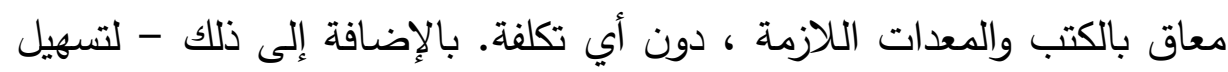

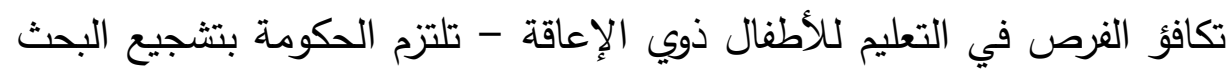

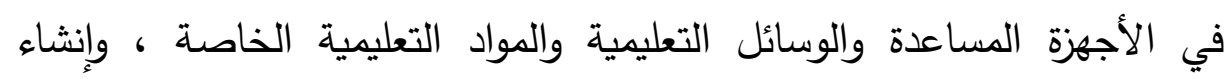

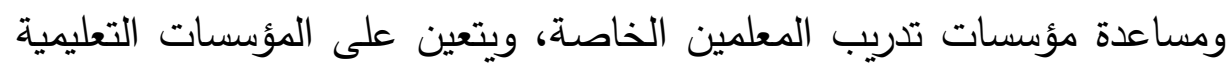

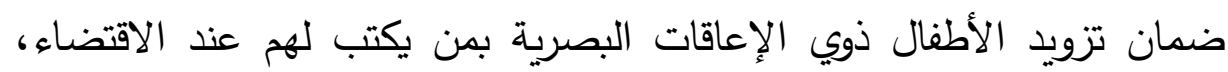

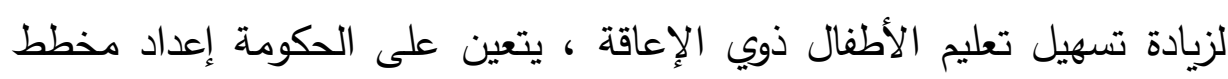

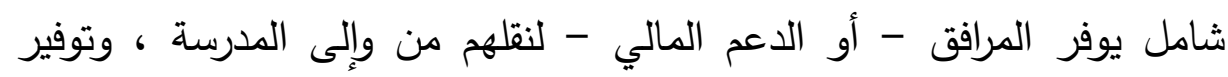

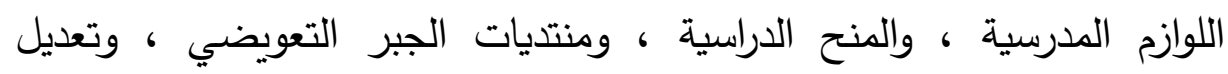

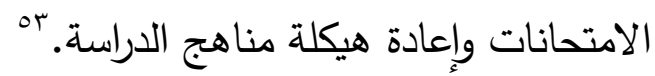

${ }^{\circ}$ Amy Raub, Isabel Latz, Constitutional Rights of Persons with

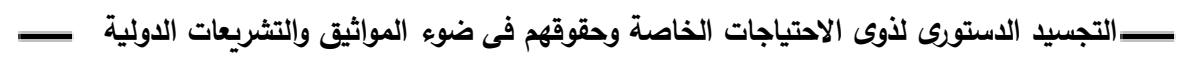

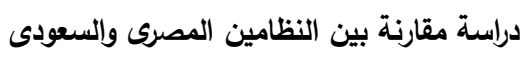




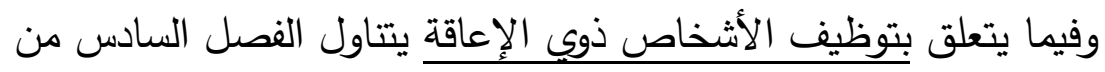

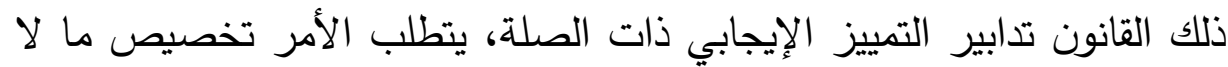

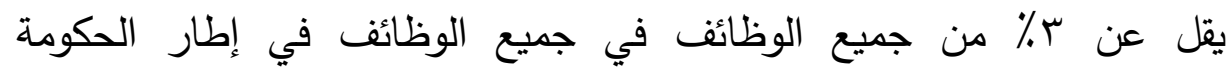

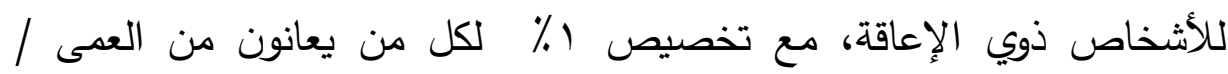

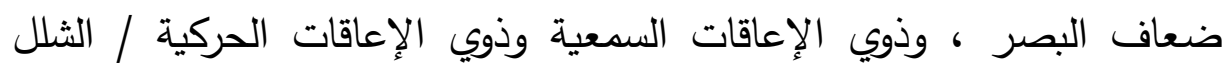

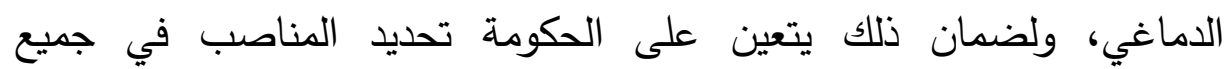

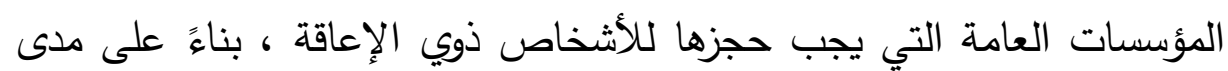

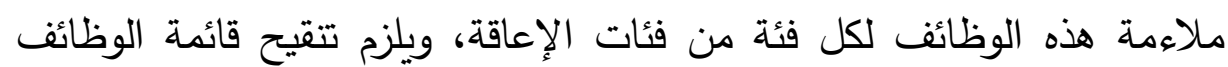

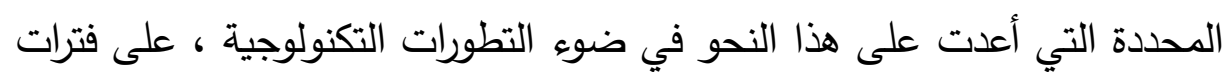

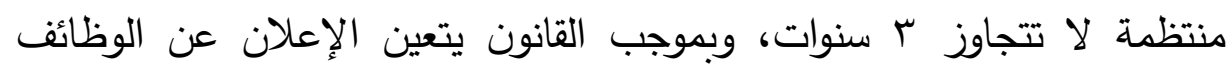

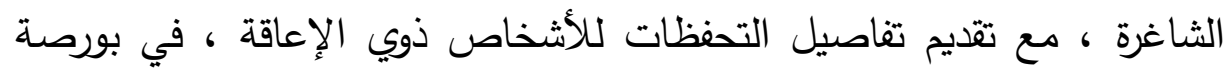
التوظيف الخاصة ، وإذا لم يتم شغلها ، سيتم ترحيلها إلى سنة التوظيف التالية،

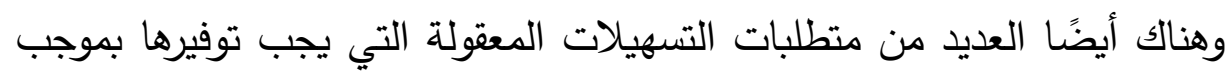
القانون مثل التغاضى عن الحد الأدنى للسن ، التدريب ، تهيئة بيئة مواتية

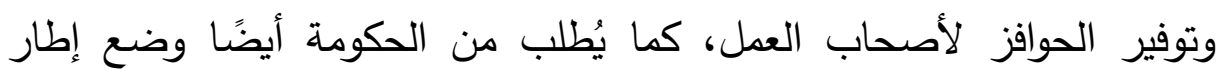
تأمين لموظفيها ذوي الإعاقة ، ويُحظر صراحةً التمييز ضد الدماني الموظفين الذين

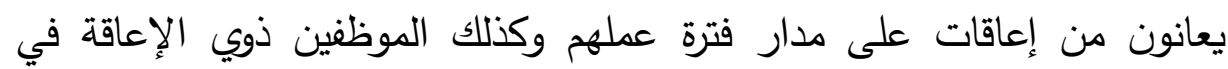
مسألة الترقيات، وأخيراً ، بالنسبة للأشخاص ذأن ذوي الإعاقة المسجلين في بورصة

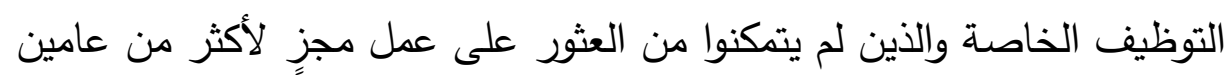

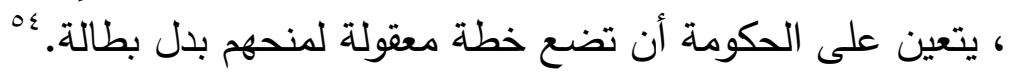

Disabilities: An Analysis of qr National Constitutions, Harvard Human Rights Journal / Vol. rq, r. 1 7, p. r. 7

of Kalpana Kannibiran, Monitoring the Human Rights of Persons with Disabilities, op, cit, p. rr 


\section{المبحث الثانى}

التجسيد الاستورى لذوى الاحتياجات الخاصة وحقوقهم فى مصر والسعودية

$$
\text { المطلب الأول }
$$

التجسيد الاستورى لذوى الاحتياجات الخاصة وحقوقهم فى مصر

اهتمت مصر بذوى الاحتياجات الخاصة حيث يتضمن الدستور 11 مادة

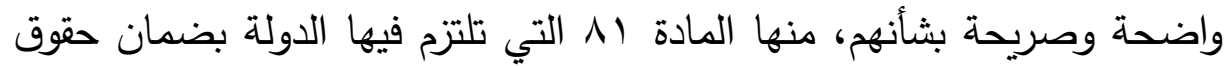
الأشخاص ذوي الإعاقة، والمادة سه التي تتص على على أنّ المواطنين لادى القانون

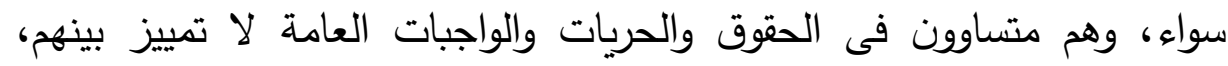

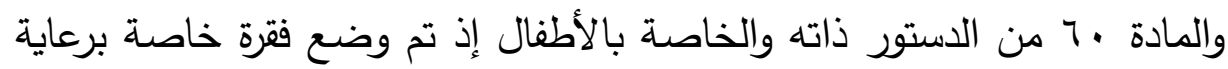
الأطفال ذوى الإعاقة، وبذلك ضمن الدستور لهذه الفئة الحقوق والحريات وتوفير فرص العمل، وتمكينهم من المساواة مع غيرهم ودمجهم في التعليم. ا. حقوق الأثخاص ذوى الإعاقة فى الحياة الاجتماعية والمدنية

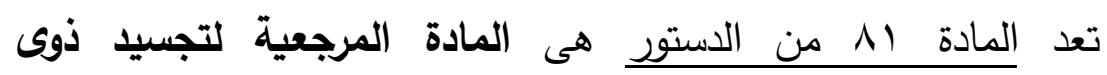

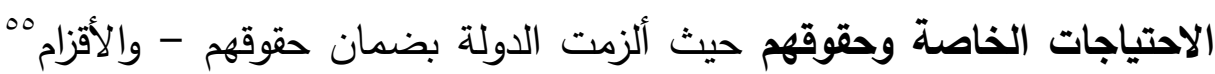
- فى النطاق الصحى والاقتصادى والاجتماعى والثقافى والترفيهى والرياضى واتى

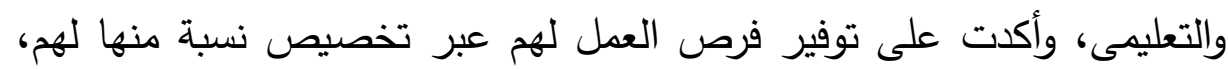

• وفقا لقانون حقوق الأشخاص ذوى الإعاقة - سابق الإشارة إليه - يعتبر الأشخاص الذين

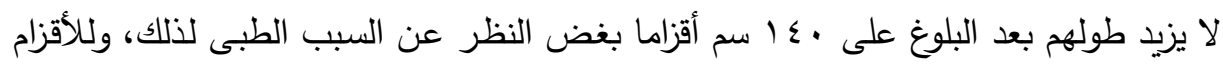
كافة حقوق الأشخاص ذوى الإعاقة منذ اكتثاف قزامتهم.

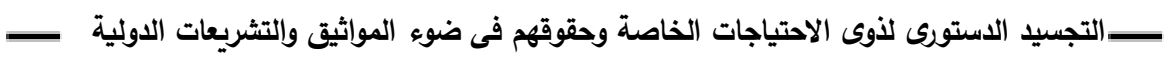

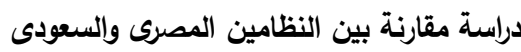


وتهيئة المرافق العامة والبيئة المحيطة بهم، ودمجهم مع غيرهم من المواطنين،

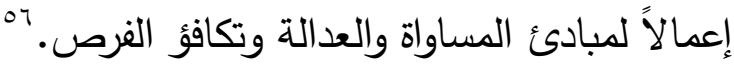
ويلاحظ الباحث أن المادة تراعى المعايير الدولية فى هذا الثأن كالتأهيل والدمج والمباديء الدولية ذات الصلة كالمساواة مع الآخرين والعدل وتكافئ لإني الفرص، وقد أضاف قانون حقوق الأشخاص ذوى الإعاقة تفسيرا للدمج بأنه

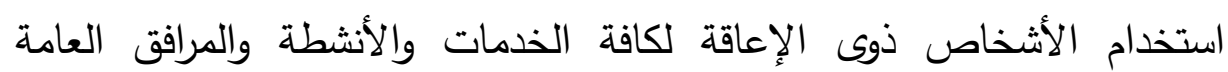

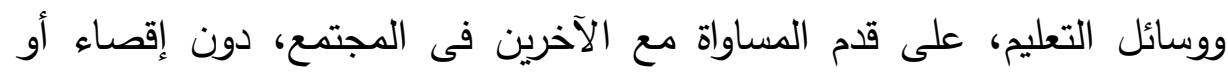
استبعاد فى شتى مناحى الحياة من خلال السياسات والخطط والتدابير والبرامج التحني المناسبة والتوعية المجتمعية والمشاركة الفعالة. كما أن المادة أخذت بمبدأ التمييز الإيجابى عبر تخصئة وكيص الته حصة (كوتا)

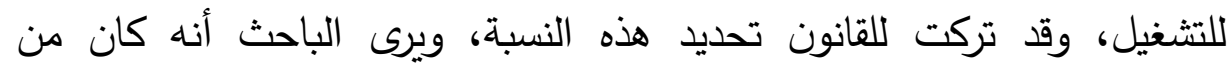
الأفضل للمشرع الاستورى تحديد هذه النسبة أو حدها الأدنى لأن التمييز

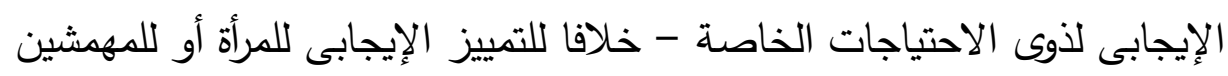
- هو تمييز دائم بطبيعته. كما تقرر المادة به من الدستور أن المواطنين متساوون أمام القانون فيما يتعلق بحقوقه وحرياتهم وواجباتهم العامة، بلا تمييز لأى سبب كان،

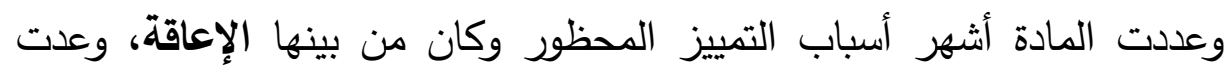
التمييز والحض على الكراهية جريمة، معاقب عليها قانونا، وألزمت الدولة باتخاذ التدابير المطلوبة لكى تقضى على كل صور التمييز ، وأضافت إنشاء مفوضية

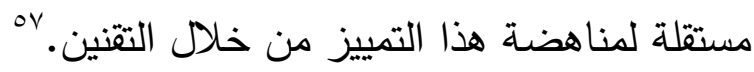

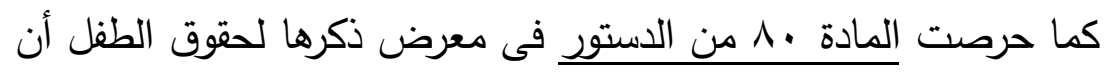

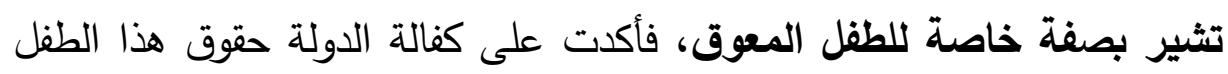

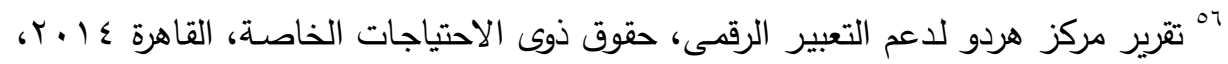

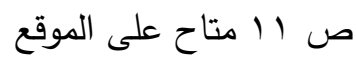

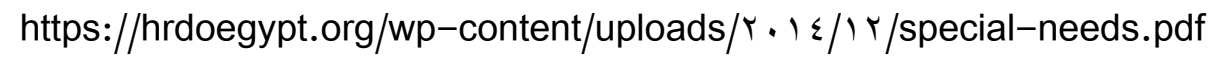

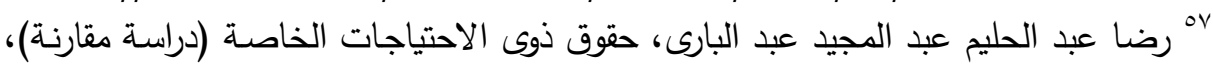

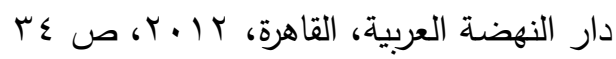

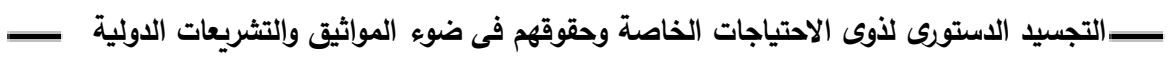

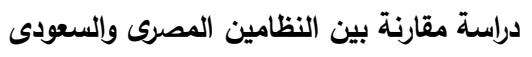


وأخصها ما يتعلق بتأهيله واندماجه في الهتمع، مع التزام الدولة تجاهه - وتجاه

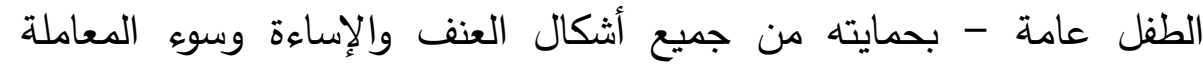
والاستغلال الجنسى والتجارى.

وبعد أن تحدثت المادة ؟0 من الدستور عن الحرية الثخصية وصيانتها

وضوابط القبض والتفتيش وحقوق الدفاع والتحقيق ذكرت ما نصه "مع توفير

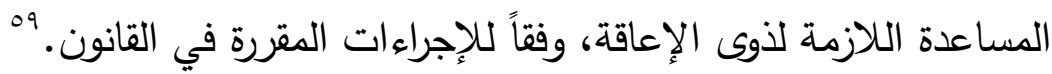

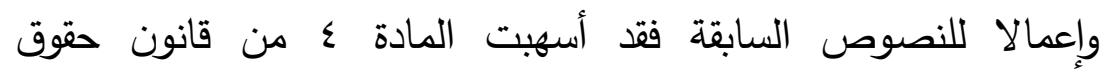
الأشخاص ذوى الإعاقة فى سرد عشرين حقٍ - على سبيل المثال - تلتزم الدولة

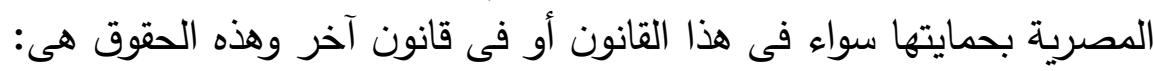

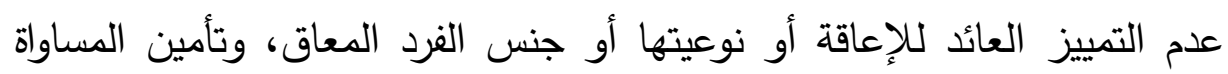
العملية لأجل التمتع بكل حقوق الإنسان والحريات الأساسية فى كل المجالات

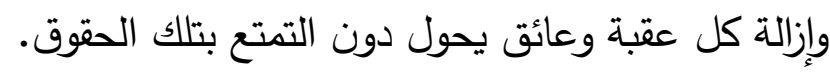

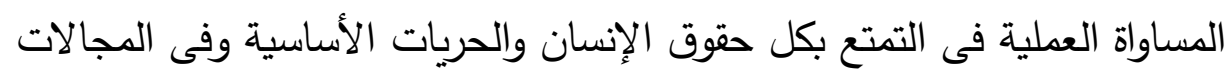
المدنية والسياسية والإنسانية والاجتماعية والاقتصادية والحريات الأساسية.

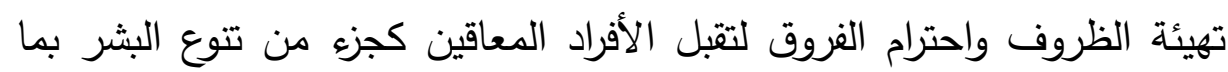
يحقق تكافؤ الفرص بينهم وبين غيرهم.

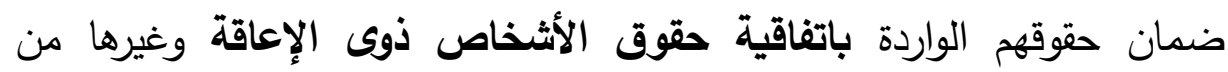

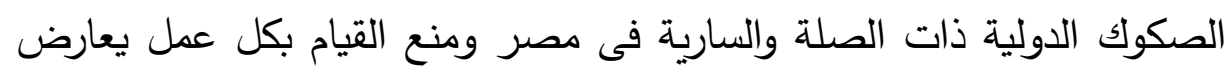
أحكام هذه الصكوك. احترام الحرية فى ممارسة خيارات المعاق بنفسه وبإرادته المستقلة .

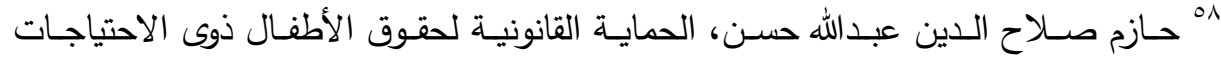

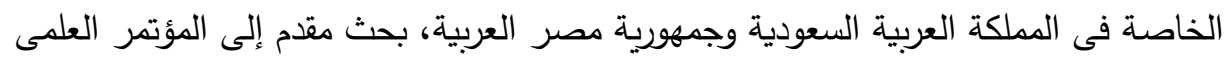

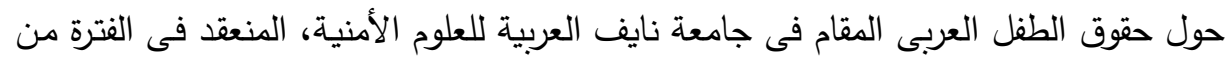

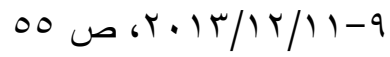

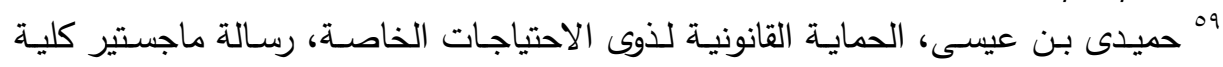

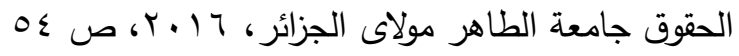

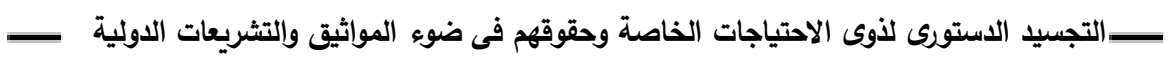

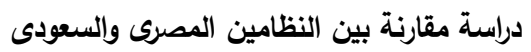


حق الأفراد ذوى الإعاقة فى تعبيرهم بحرية عن الرأى وإيلائه الاعتبار الواجب

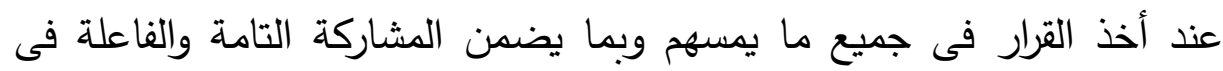
1. 1. 19تمعهم. احترام القدرة المتطورة للطفل ذى الإعاقة، واحترام حقه فى المحفاظة على هويته، وفى تعبيره عن رأيه بحرية فى كل مسألة تمسه، مع إيلاء الاعتبار الواجب لرأيه

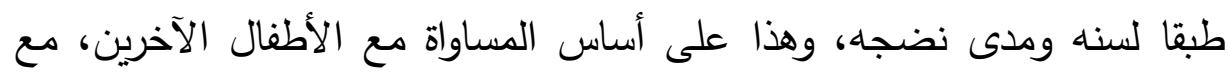

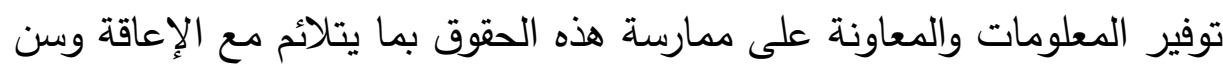
الطفل. "توفيز "ال" تكافؤ الفرص بين الأفراد ذوى الإعاقة وغيرهم. المساواة بين الرجل والمرأة من ذوى الإعاقة. منع حرمان الأفراد ذوى الإعاقة من حقهم فى التزاوج وتأسيس الأسر برضئ داء تأماه.

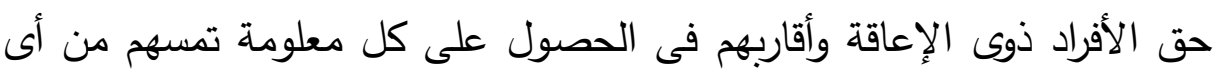

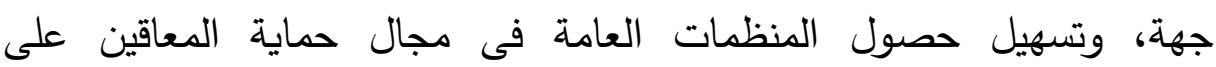
المعلومات الخاصة بالخدمات التى يقدمونها للأفراد ذوى الإعاقة.

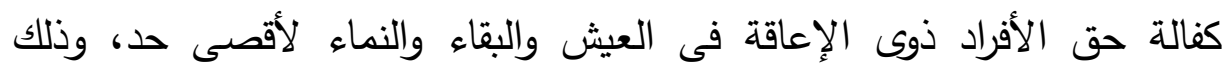
بتسهيل التدابير اللازمة فى إطار من احترام كرامتهم الإنسانية، لتوفير أكبر مستوى يمكنهم من مقومات الحياة الجوهرية كالمأكل والسكن والرعاية الطبية والاجتماعية والنفسية وغير ذلك، وتمكين المعاق من ممارسة حقه فى التعلم

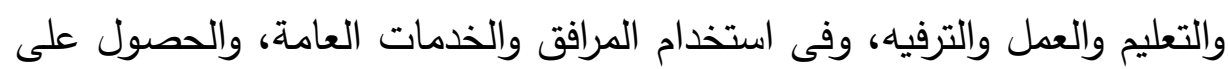
المعلومة وحرية تعبيره. بناء وتطوير قدرة المتعامل مع الأفراد ذوى الإعاقة على أن يشمل ذلك الجهاز

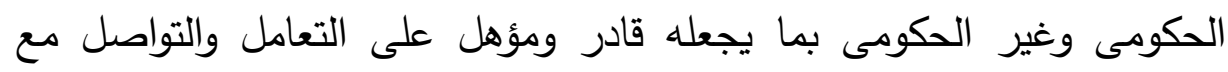

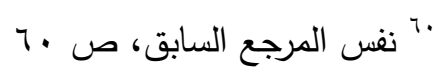

" "محمد صلاح عبد الرسول، دراسة التغيرات الناتجة عن الدمج بين الأطفال الأسوياء والأطفال

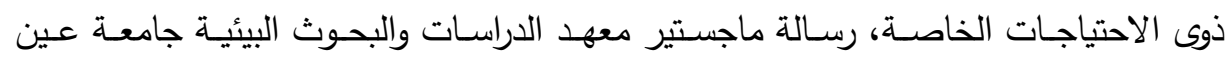

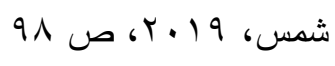

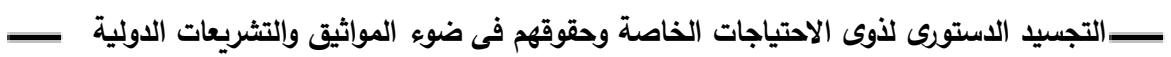

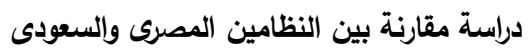


الأفراد ذوى الإعاقة فى جميع القطاعات، وتثجيع تدريب الأخصائى والموظف العامل مع الأفراد ذوى الإعاقة فى نطاق الحقوق المعترف بها دوات دوليا لتحسين

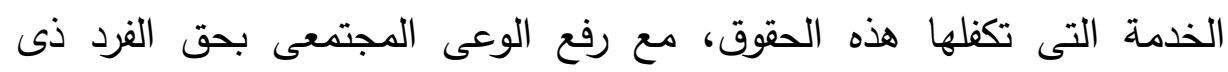

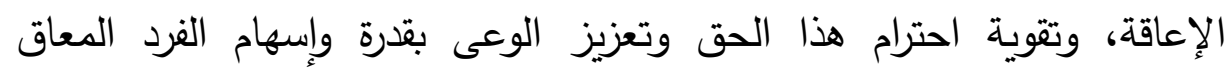

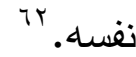

اتخاذ التدبير اللازم الذى يضمن وصول الفرد المعاق للبيئة المادية المحيطة ولوسائل النقل والاتصالات والتكنولوجيا والمعلومات، بما يقوى قدراته ومهاراته، وإجراء وتقوية البحوث ذات الصلة بمجال حقوق الفرد المعاقة الذى يفعل قدراته ومهاراته وضمان نفاذه لوسائل الاتصالات وتكنولوجيا المعلومات، وتعزيز توفرها

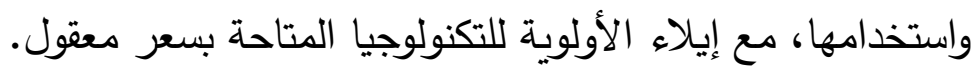
تمكين الأفراد ذوى الإعاقة من الاشتراك فى تسهيل الشئون العامة على قلى قدر

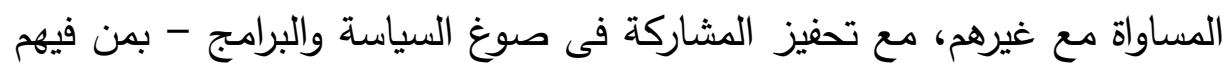

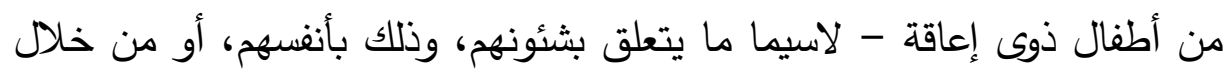
أقاربهم أو ممثليهم من منظمات مختلفة.

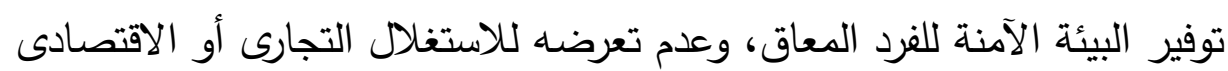

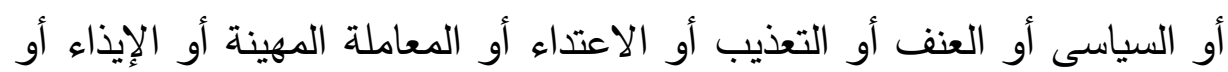
التقصير أو الإهمال أو التأثير على أى حق من حقوقيه.

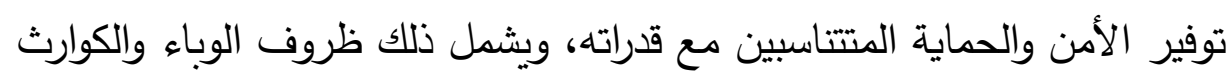

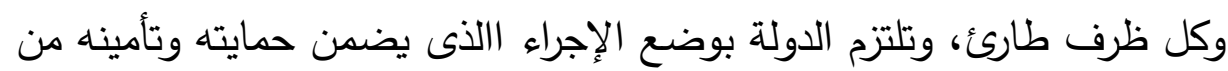

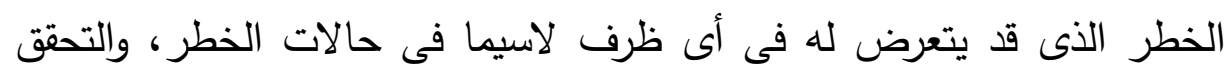
مما يتعرض لله من إساءة.

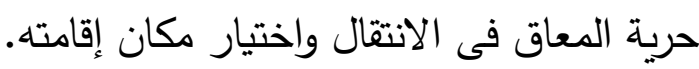
حقه فى الحصول على الجنسية طبقا للقانون على قدر المساواة مع غيره.

"ז جميلة ربيع إبراهيم سيد، آليات تفعيل خدمات الرعاية الاجتماعية لذوى الإعاقة، رسالة

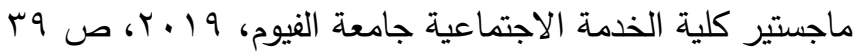

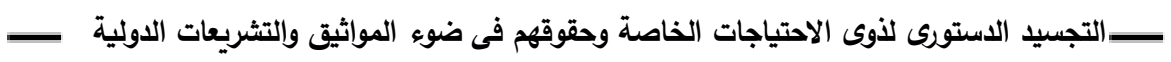

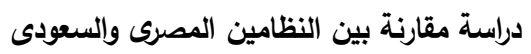


توفير التأهيل والتدريب والإرشاد والتوعية والمساندة اللازمة لأسرة المعاق، كونها مكانا طبيعيا لحياته وتوفير الظروف المناسبة لرعايته داخلها.

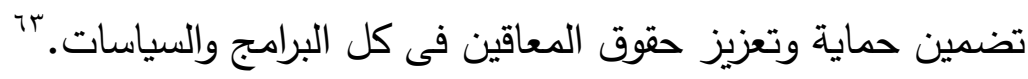

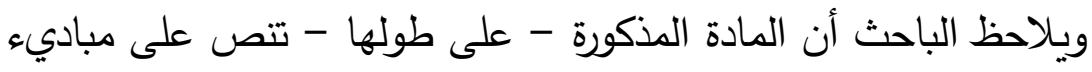

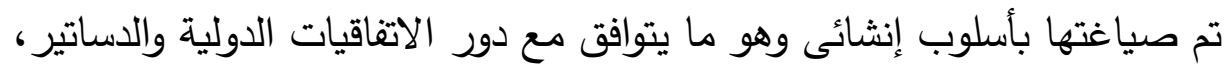

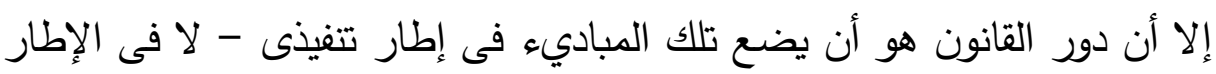
الدعائى - الخطوات والإجراءات اللازم أخذها. وقد جمع القانون بين المفهوم الطبى والاجتماعى للإعاقة حيث أشار التهار

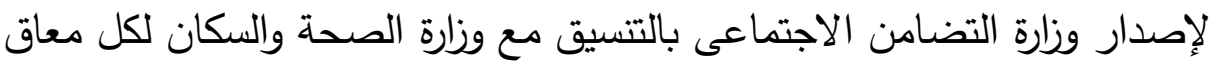

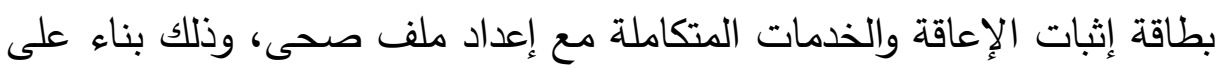

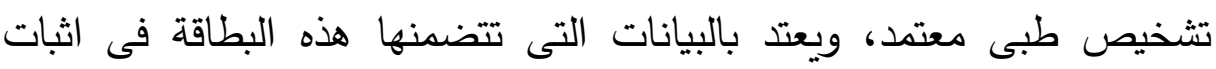
الإعاقة ودرجتها ونوعها أمام كل الجهات ذات الصلة التى يتعامل معها لتهان المعاق سواء كانت جهة حكومية أو غير حكومية، ويشمل هذا جهة التحقيق والمحاكمة، ونهام

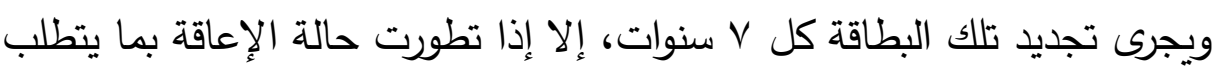

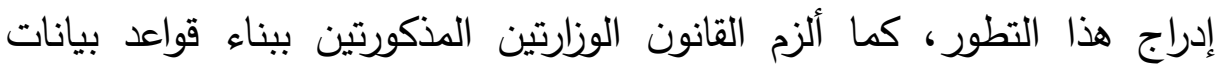

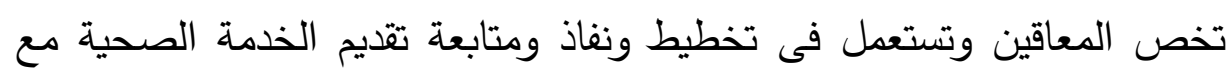
مراعاة سرية بياناتها. وفى مجال الرعاية الصحية ألزم القانون المشار إليه وزارة الصحة والسكان وغيرها من الأجهزة المعنية بالآتى: وضع وتحديث برامج الرابة الكثف المبكر

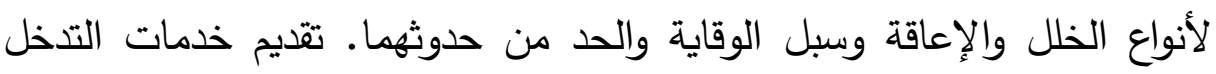
المبكر. تقديم خدمات التأهيل الطبى فى كافة مراكز الرعاية الصحية. تقديم خدمات التأهيل الطبى فى كافة مراكز الرعاية الصحية. تلتزم الجهات الحكومية

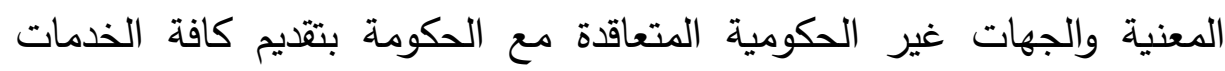
الصحية والوقائية والعلاجية المتخصصة والداعمة للأشخاص ذوى الإعاقة وكذا

"ז" هبة عاطف السيد محمود عوض، دور الجمعيات الأهلية فى تفعيل حماية حقوق المعاقين،

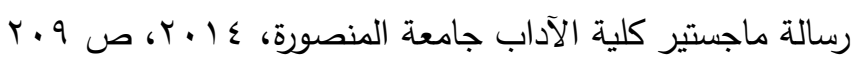

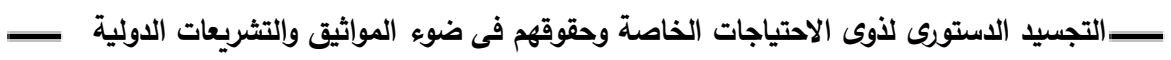
دراسة مقارنة بين النظامين المصرى والسعودى في الكيات 
توفيق مرافقها ومنشأتها وفق الكود الهندسى الواجب توافره فى المبانى والمرافق

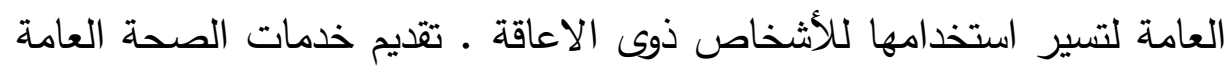

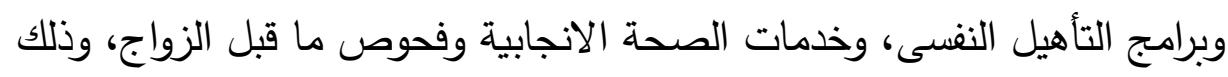

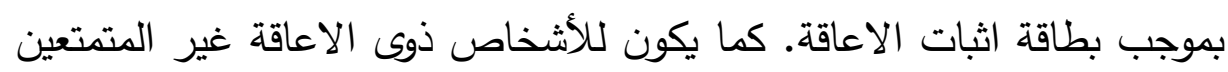
بخدمات التأمين الصحى الحق فى الحصول على كافة هذه الخدمات بموجب

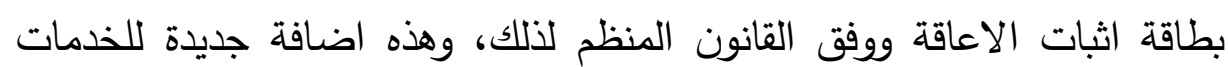
المقدمة للأشخاص ذوى الاعاقة.

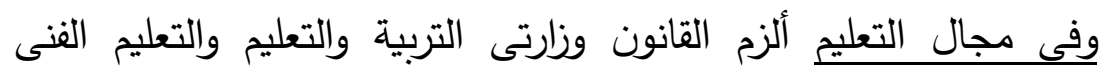
والتعليم والعالى والبحث العلمى ومؤسسات التعليم الأزهرى والوزارات والجهات

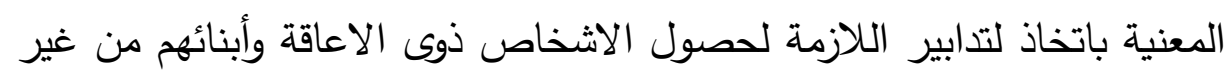

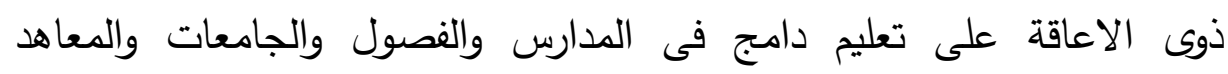

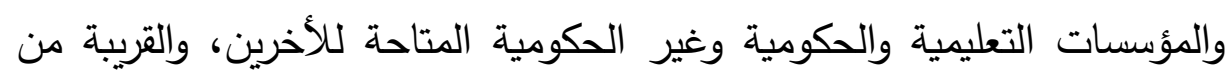
محال اقامتهم فى ضوء درجة ونوع الإعاقة على أن يتوافر فيها معايير الجودة

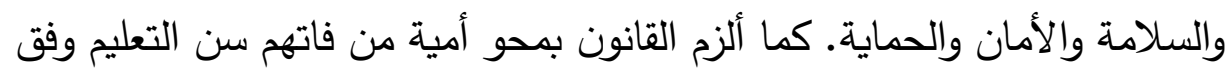

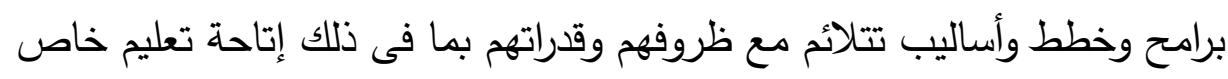
مناسب للحالات الاستثائية الناتجة عن طبيعة ونسبة الإعاقة. وألزم مؤسسات

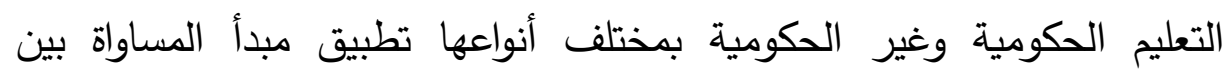

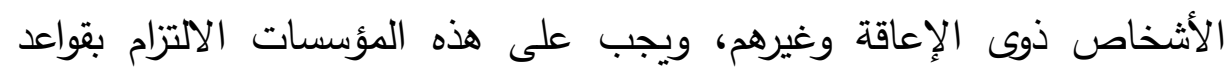

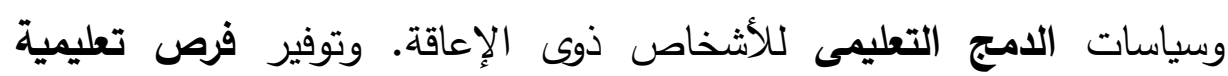

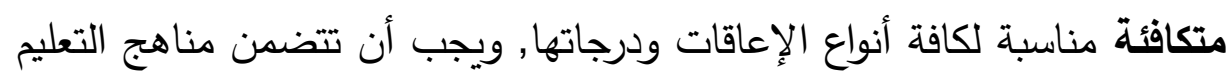

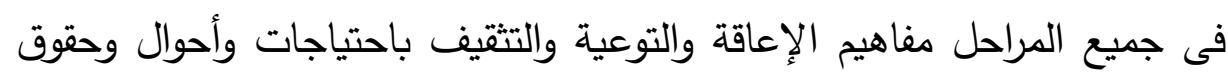

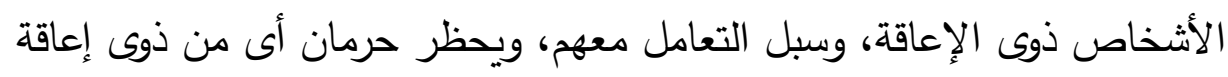

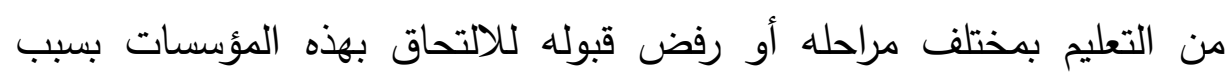

؛4 أسماء محمد خميس الدرمكي، مشكلات الإعاقة.. التحديات والحلول، فبراير 19 ــ دراسة

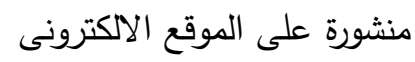

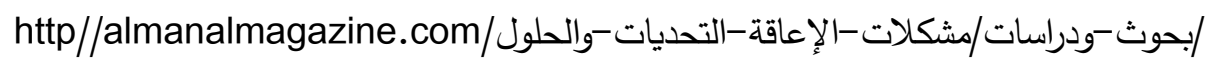

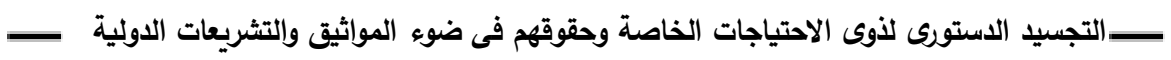
دراسة مقارنة بين النظامين المصرى والسعودى في الكيات 
الإعاقة، وفى حالة مخالفة ذلك تتولى الجهة الإدارى المختصة إنذار المؤسسة

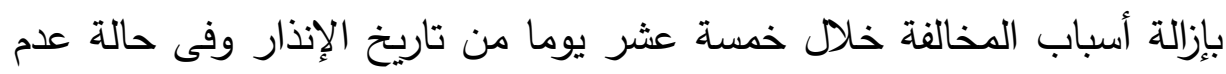

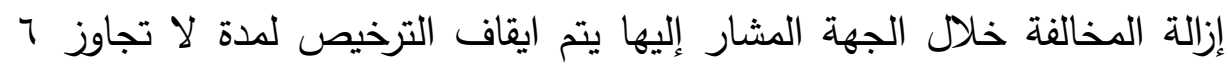
أشهر وفى حالة عدم إزالة هذه المخالفة سيتم سحب ترخيص المؤسسة. كما يجب ألا تقل نسبة القبول لذوى الإعاقة عن ه \% من من المقبولين فى مؤسسات

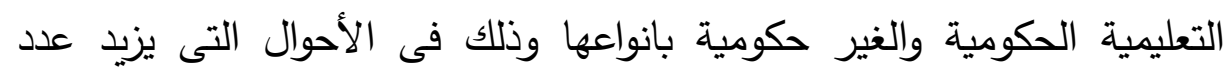

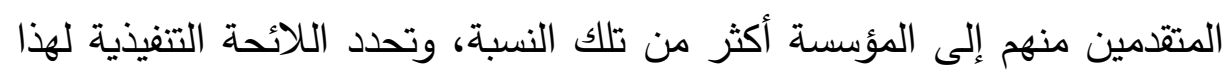
القانون شروط وقواعد وإجراءات قبول هؤلاء الأطفال فى تلك المؤسسات.

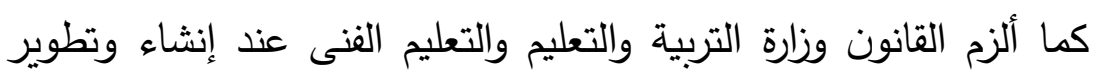
مدارس التربية الخاصة القائمة الالتزام بالمعايير العلمية الحديثة لجودة هذئ ولتهي

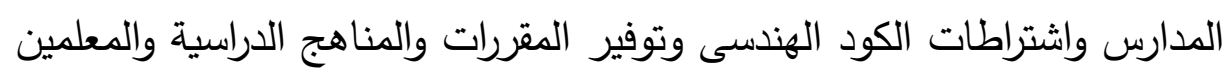
والأخصائيين الددربين والعمال المؤهلين لذلك وفقا لكل إعاقة. كما تلتزم الدولة

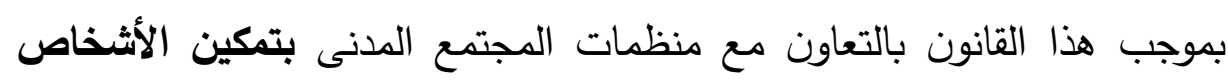

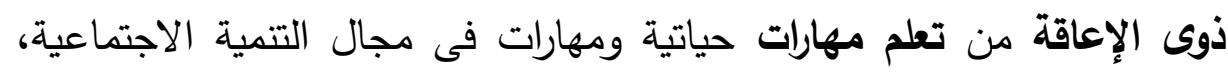

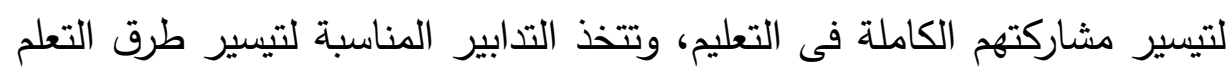

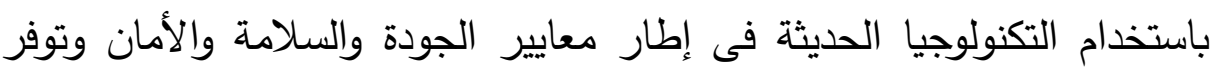

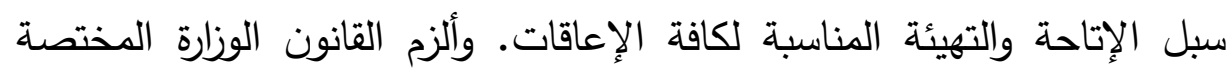

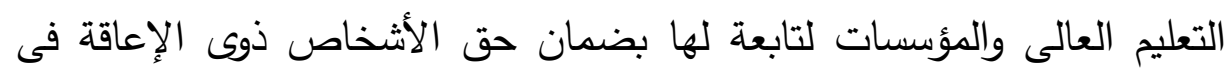

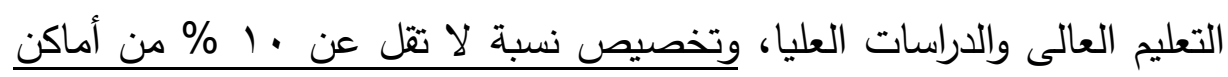

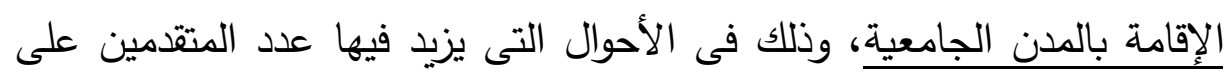
تلك النسبة، ومعادلة شهادتهم الحاصلين عليها وفقا للقواعد المنظمة، وتلتزم الوزارة المختصة بالتعليم العالى والمؤسسات التابعة لها بتوفير الترتيبات التيسيرية

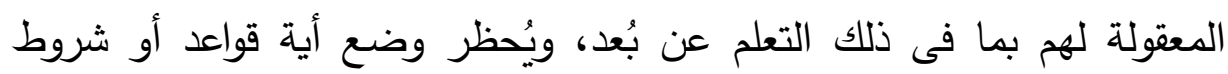

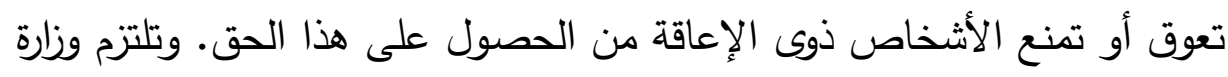

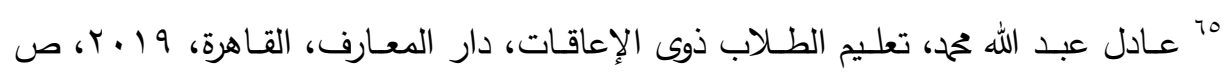


التعليم العالى بإنشاء الكليات والمعاهد المتخصصة فى إعداد وتخريج كوادر للعمل بمجال الإعاقة بمختلف أنواعها.

وفى مجال التشغيل ألزم القانون الوزارة المعنية بشئون العمل والجهات الإدارية التابعة له بإنشاء سجل لقيد الأشخاص ذوى الإعاقة راغبى التهى العمل،

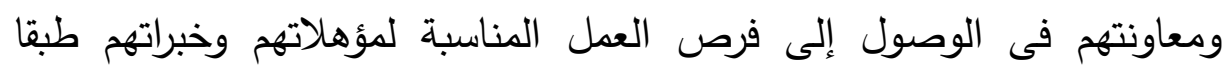

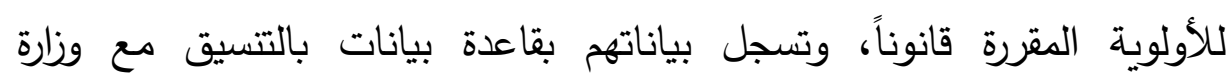

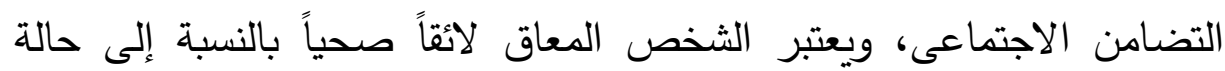
العجز الواردة بشهادة التأهيل المنصوص وعنئرعاعلئيا في هذا القانون وذلك استثناء من

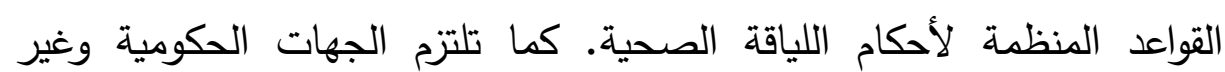
الحكومية وقطاع الأعمال وكل صاحب عمل ممن يستخدم عشرين عاملاً فأكثر وغئر

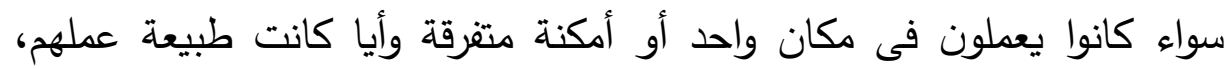
بتعيين نسبة ه\% من عدد العاملين على الأقل من الأشخاص ذوى الإعاقة الذين

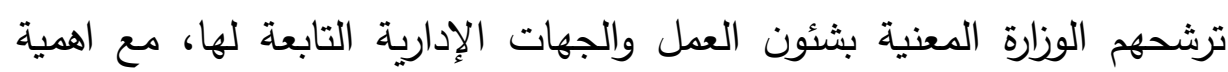

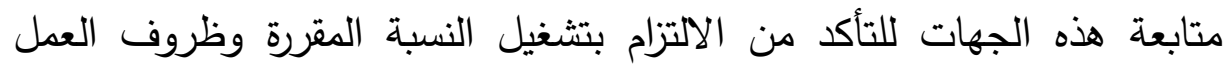
وفرص تثغيل الأشخاص ذوى الإعاقة وكافة الالتزامات التى نظمها هذا القانون

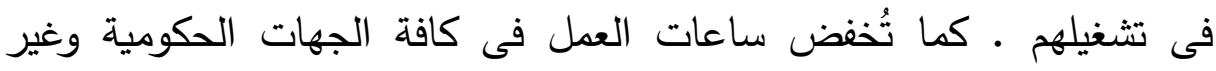

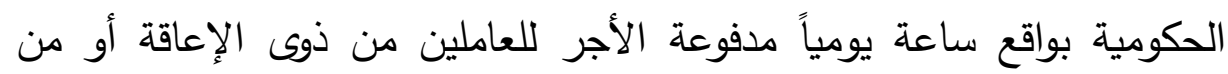
يرعى شخصاً من ذوى الإعاقة من درجتى القرابة الأولى والثانية .

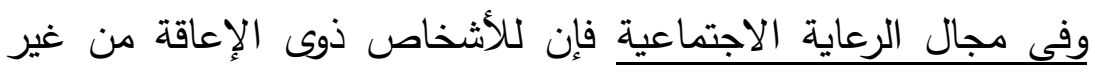

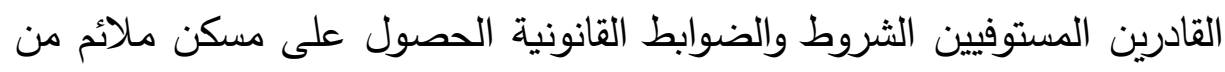

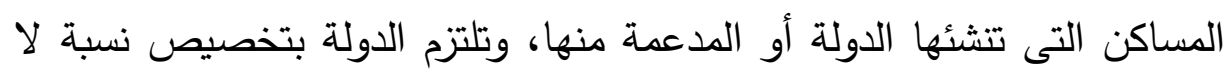
تقل عن ه\% من هذه المساكن للأشخاص من ذوى الإعاقة المختلفة وينشأ بوزارة

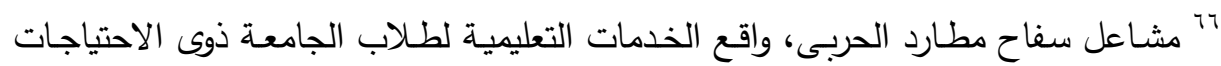

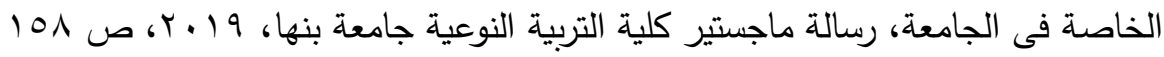

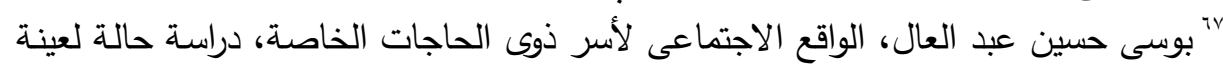

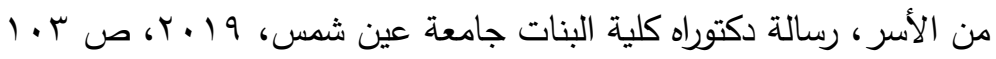

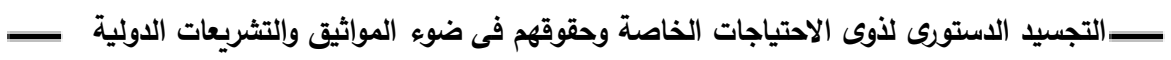

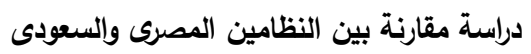


الإسكان ومديريات الإسكان بالمحافظات سجل تقيد به البيانات طالب الحصول

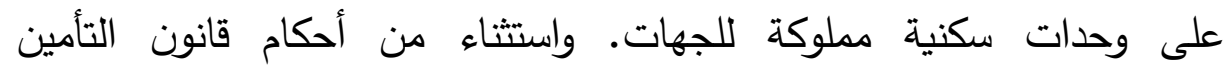

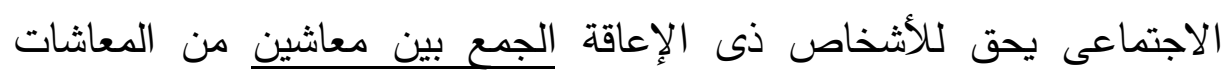

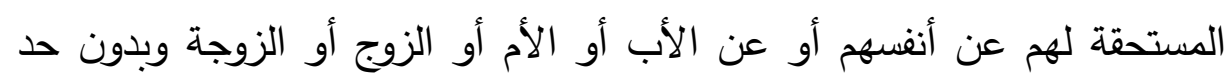

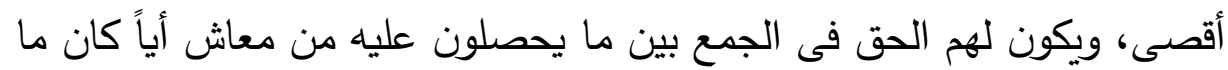

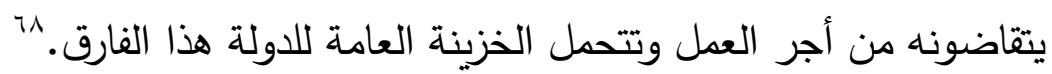
كما تلتزم الجهات الإدارية المختصة بشئون التخطيط والتنظيم وكافة الجهات المختصة المبينة بقانون البناء باشتراطات الكود الهندسى المصرى لإنهاته لتصميم والفراغات الخارجية والمبانى لاستخدام الأشخاص ذوى الإعاقة، وذلك لكاتك

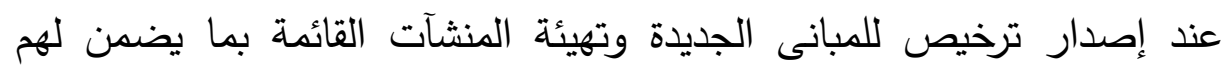

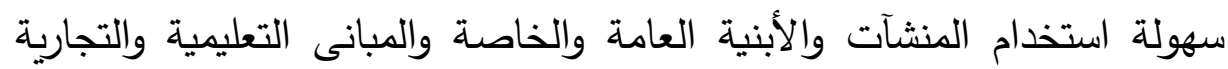

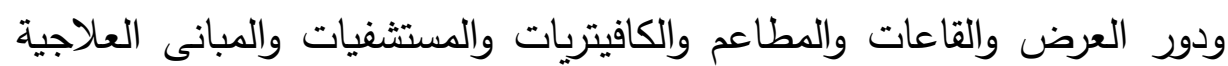
والطرق والأرصفة والكبارى والأنفاق ومرافقه. كما تلتزم الدولة والوزارات المختصة بالنقل والجهات والانفاف ومرافهة المعنية الأخرى بوضع النظم اللازمة لإتاحة وتيسير انتقال ونقل الأشخاص ذوى الإعاقة، بما فى لئ

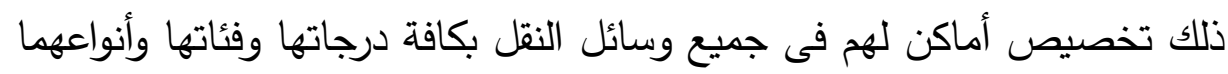
وبتخفيض اجرائتها بنسبة ـ0 \% من قيمتها المدفوعة وذلك بالنسبة للشخص ذئ ونى

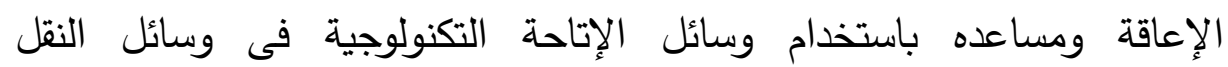
والمواصلات.

كما تلتزم جميع وسائل الإعلام الحكومية وغير حكومية بإتاحة اللغات اللازمة لتمكين الأشخاص ذوى الإعاقة وتيسير تواصلهم مع المواد الإعلامية

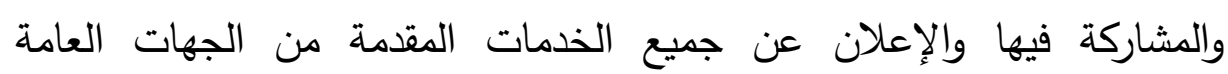

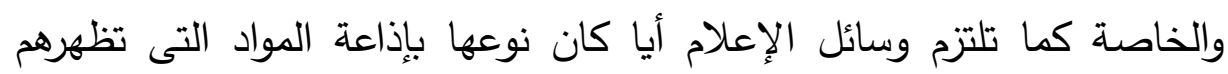
بصورة إيجابية وتحترم كرامتهم المتأصلة.

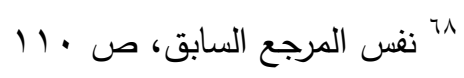


وفى المجال الثقافى والترفيهي ألزم القانون الوزارات والجهات المختصة بالثقافة بإتاحة وتيسير مشاركة الأشخاص ذوى الإعاقة فى الأنشطة الثقافية

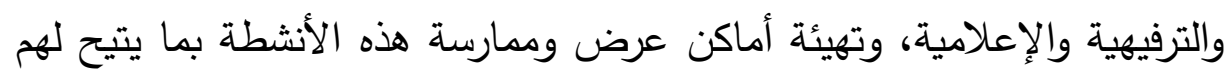

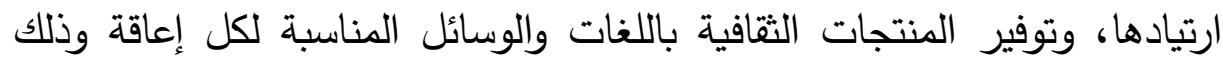

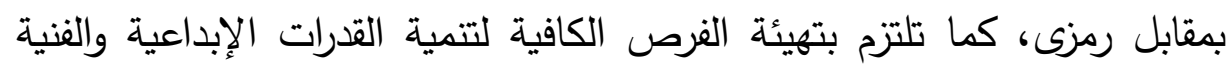

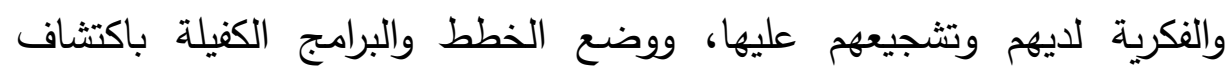
الموهوبين منهم والاعتراف بهوايتهم الثقافية والغوية الخاصة ودعم الأنشطة الفنية الثقافية لهم ومعارضهم ونشر اعمال المتميزون من مبدعيهم. كما ألزم القانون

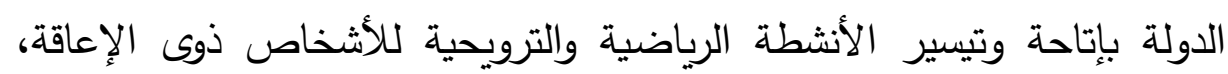

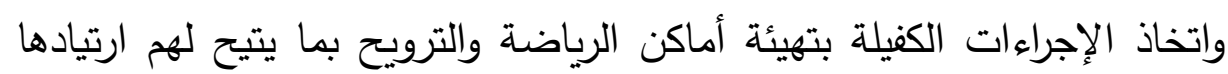
وتوفير الأساليب والوسائل التى تيسر حصولهم على فرص التدريب والمشاركة

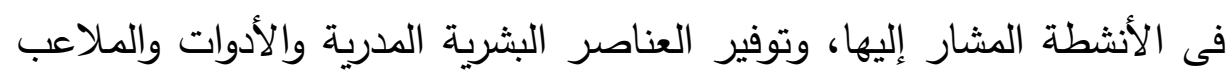

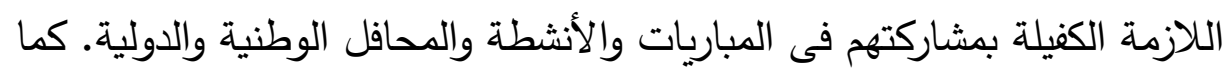

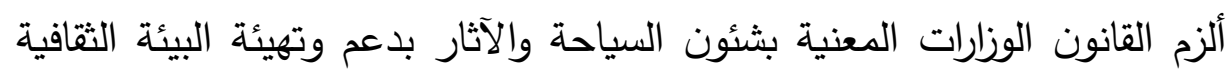

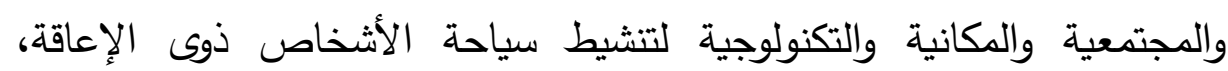
والارتقاء بمستوى الخدمات السياحية المقدمة لهم فى كافة المحافل والأماكن

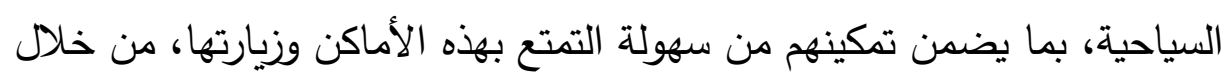

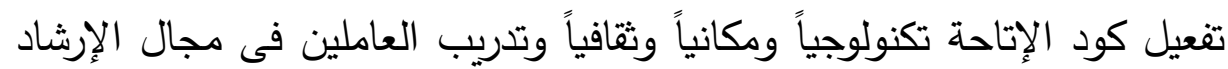

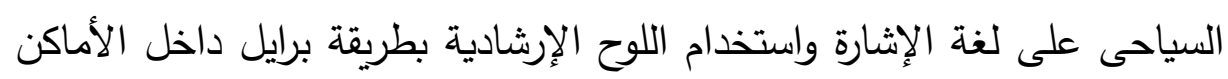

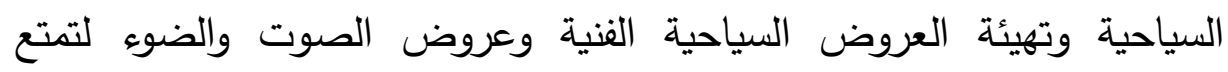
الأشخاص ذوى الإعاقة بمشاهدتها وارتيادها، ودعم المهرجانات السياحية والفنية

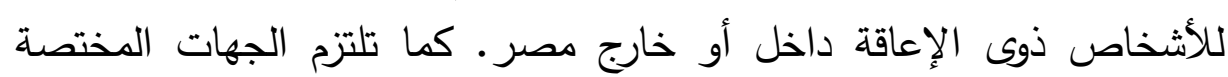

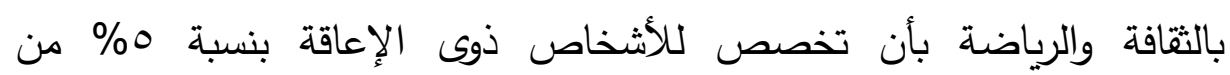

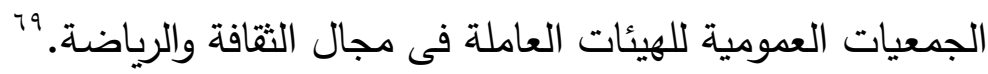

"9 جميلة ربيع إبراهيم سيد، آليات تفعيل خدمات الرعايـة الاجتماعية لذوى الإعاقة، مرجع

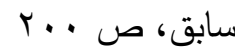
ror

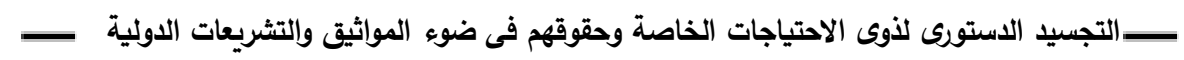

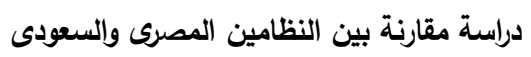




\section{r. حقوق الأشخاص ذوى الإعاقة فى الحياة السياسية}

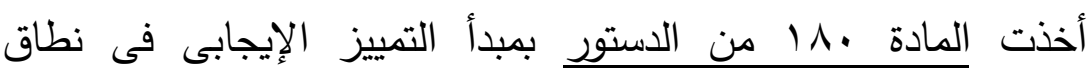

انتخابات مجالس الوحدات المحلية حيث خصصت ربع عدد المقاعد للشباب دون

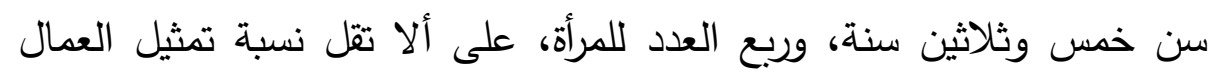

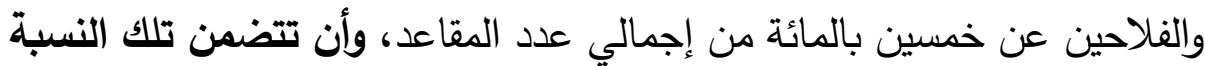

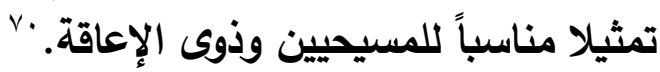
وبغض النظر عن عيب الصياغة المتعلق بذوى الإعاقة؛ فإن النص كان الإن النصاء

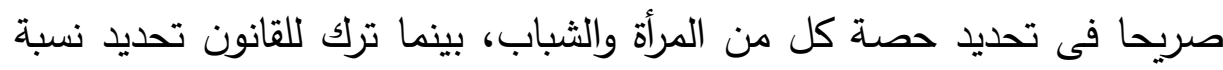
ذوى الإعاقة مقيدا إياه بكونها مناسبة، على الرغم من أن مبدأ التمييز الإيجابى لئى للمرأة والثباب يتسم بكونه مؤقت حتى يصبح عرفا اجتماعيا، بينما يظل دائما لذوى الإعاقة، فضل عن أن معيار التناسب قد يثور الخلاف حول تفسيره ويفتح الباب أمام شبهات عدم الاستورية.

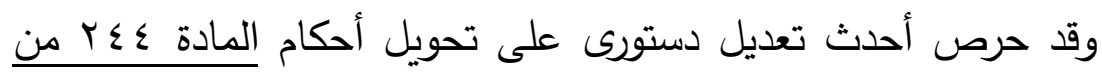

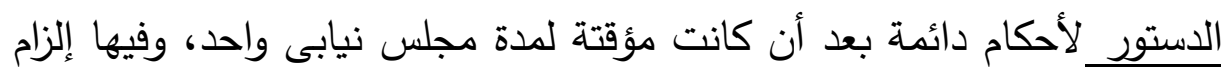
الدولة بتمثيل الشباب والمسيحيين والأشخاص ذوى الإعاقة والمصريين المقيمين فى الخارج تمثيلاً ملائماً في مجلس النواب، وذلك على النى النحو الذى يحدده

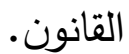

ومرة أخرى يقر المشرع الدستورى مبدأ التمييز الإيجابى فى نطاق

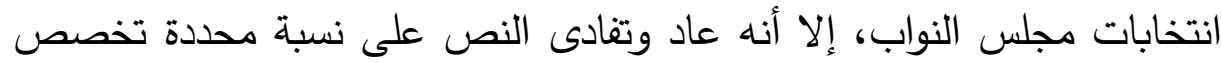

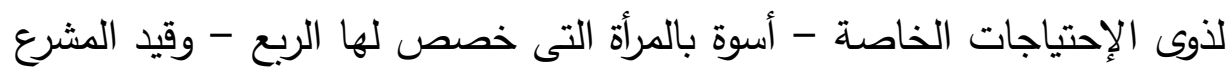

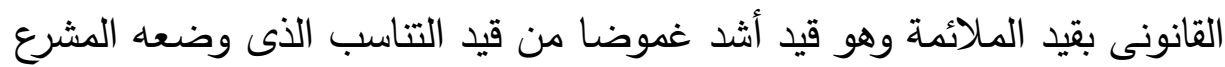

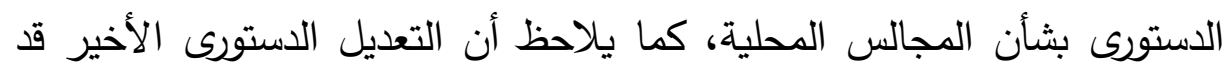

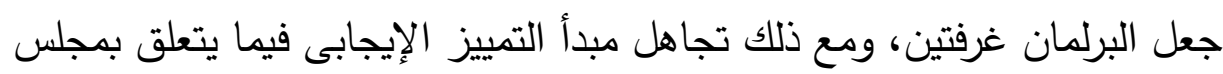
الثيوخ.

ع بترير مركز هردو لدعم التعبير الرقمى، حقوق ذوى الاحتياجات الخاصـة، مرجع سابق،

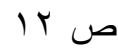

I roz

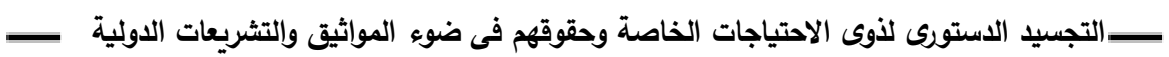

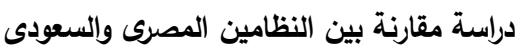


ويشار إلى أن المادة ؟ Y من الدستور فى معرض تعدادها للمجالس

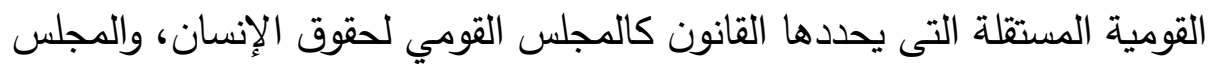
القومي للمرأة، قد حرصت على النص على المجلس القومي للأشخاص ذأوى لإنى

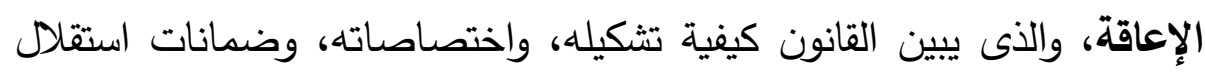

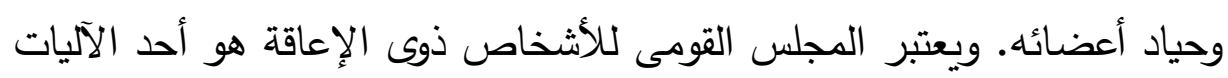

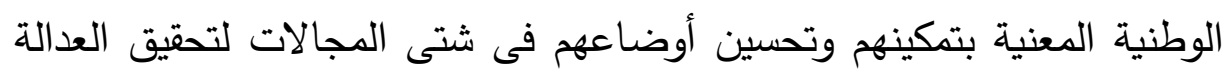

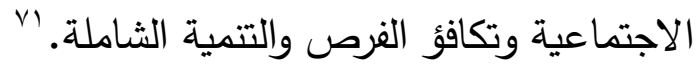

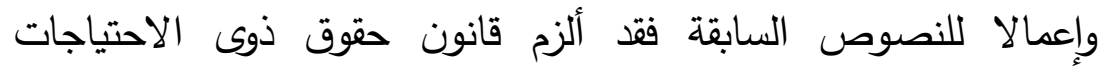
الخاصة الدولة بتمتع الأشخاص ذوى الإعاقة بكافة الحقوق السياسية التى يتمتع

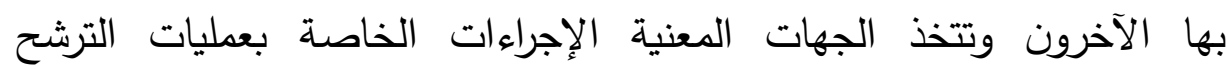
والتصويت فى الانتخابات والاستفتاءات بجميع أنواعها والأدوات الكفيلة بإتاحة وتيسير مشاركة الأشخاص ذوى الإعاقة فى هذه العمليات، بما فى ذلك الحق فى التى التى

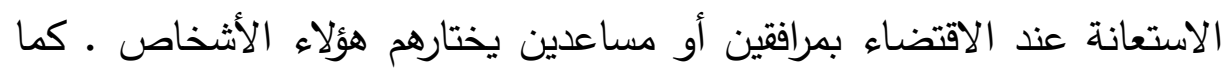

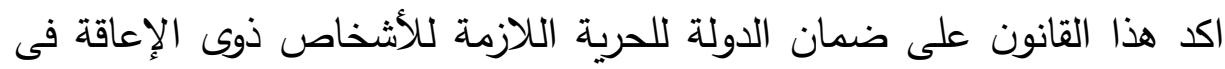

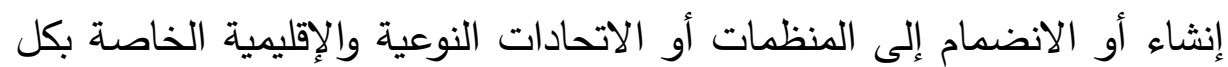

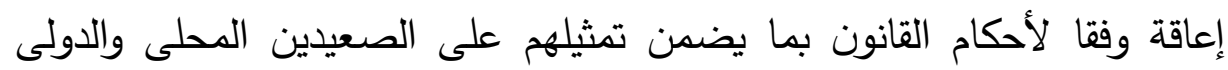
وتلتزم الأحزاب السياسية ومنظمات المجتمع المدنى والاتحادات والنقابات بإتاحة وتيسير وتثجيع مشاركة الأشخاص ذوى الإعاقة في كافة صور أنشطتها بتمثيل مناسب. وتئبر ومازال أمام المشرع المصرى مراعاة نسب التمثيل فى المجالس النيابية والمحلية لدى إقراره لهذه القوانين.

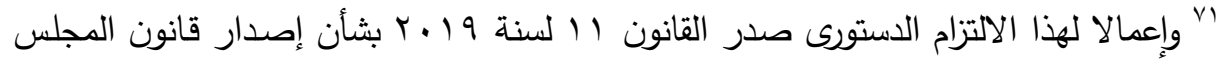

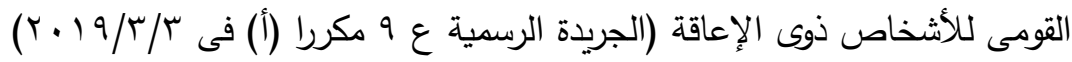

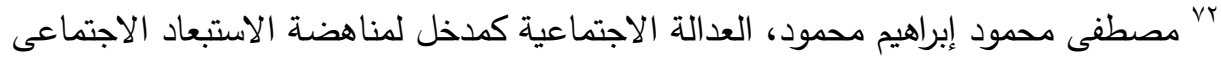

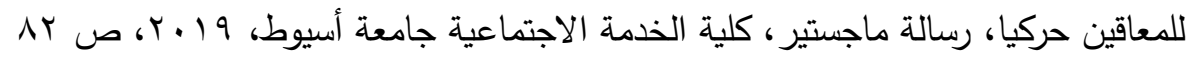




\section{المطلب الثانى}

\section{التجسيد الاستورى لذوى الاحتياجات الخاصة وحقوقهم فى السعودية}

نصت المادة جr من النظام الأساسي للحكم - والذي يشكل دستور

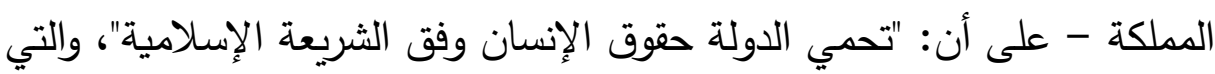
تعزز مفاهيم العدل والمساواة ومنع التمييز على أي أساس ومنها الإعاقة. كما لإنا

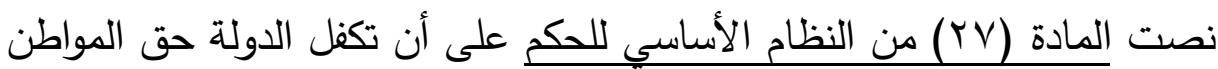

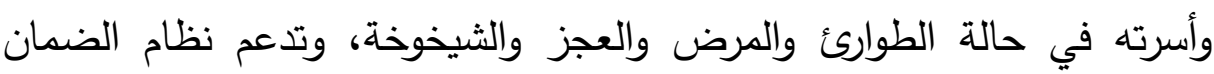

الاجتماعي وتشجع المؤسسات والأفراد على الإسهام في الأعمال الخيرية.

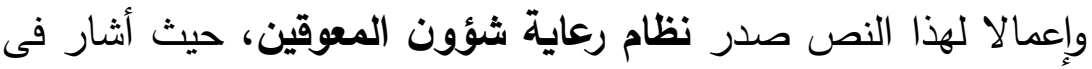

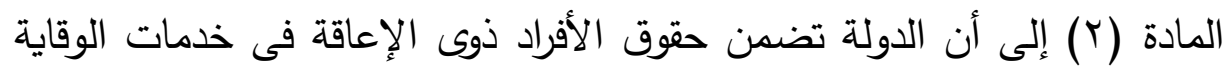

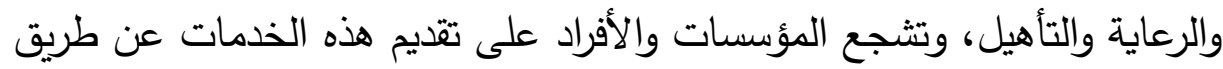
الجهات المختصة فى شتى القطاعات كتهيئة وسائل النقل العامة لتكفل انتقال هؤلاء الأفراد - ومرافقيهم - بأمن وسلامة وبأجور قليلة، فضلا عن توفير أجهزة

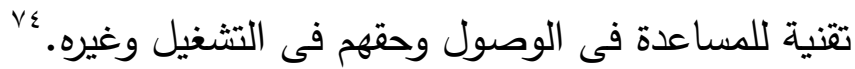
ففى المجال الصحى نص النظام المذكور على أن الخدمات التى تقدم وفئي

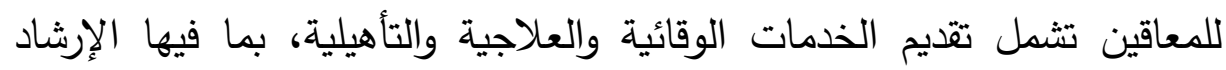

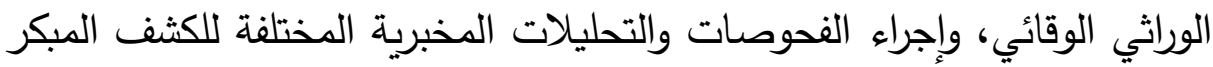
عن الأمراض، واتخاذ التحصينات اللآزمة، وكذلك تسجيل الأطفال الذين يولدون

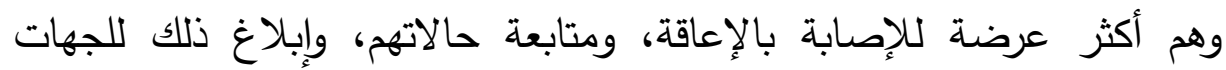

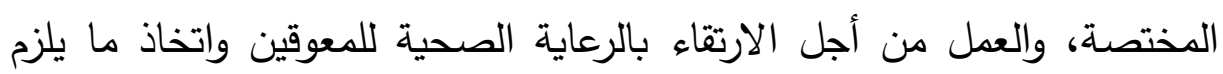
لتحقيق ذلك، وتدريب العاملين الصحيين وكذلك الذين يباشرون الحوادث على الارثاء باريه

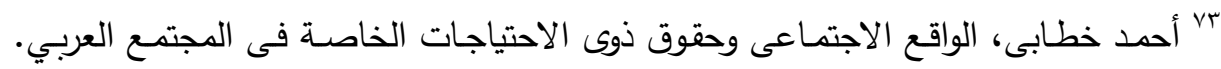

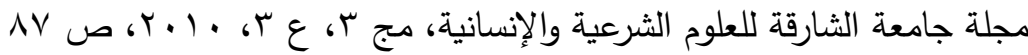

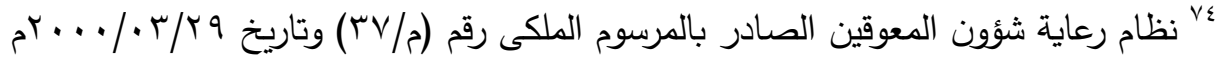


كيفية التعامل مع المصابين وإسعافهم عند نقلهم من مكان الحادث، وتدريب أسر

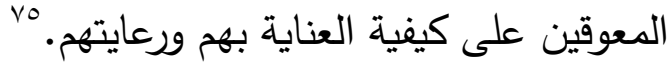

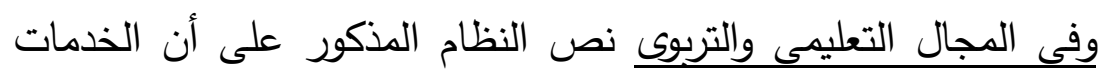

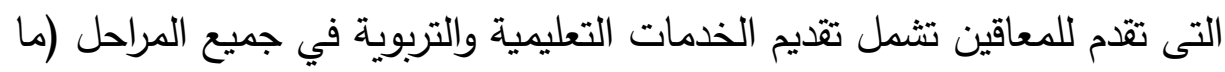

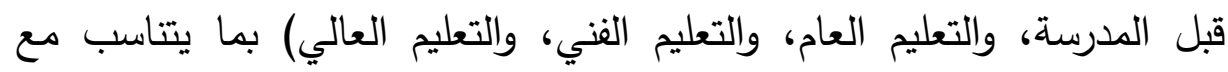
قدرات المعوقين واحتياجاتهج، وتسهيل إلتحاقهم بها، مع التقويم المستمر للمناهج ولتعايم

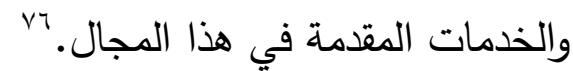
وفى مجال العمل نص النظام المذكور على أن الخدمات التى تقدم للمعاقين تشمل التوظيف في الأعمال التي تتاسب قدرات المعوق ومؤهلاته لإعطائه الفرصة للكشف عن قدراته الذاتية، ولتمكينه من الحصول على لتى دخل

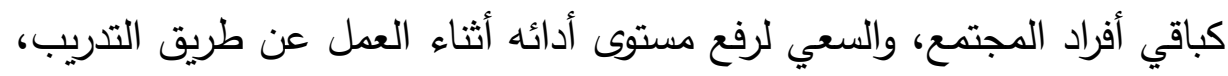

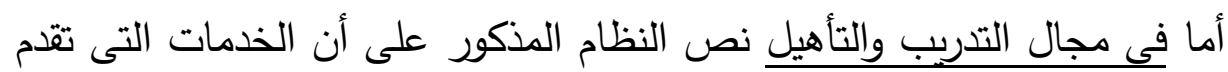
للمعاقين تشمل تقديم الخدمات التدريبية والتأهيلية بما يتفق ونوع الإعاقة ودرجتها

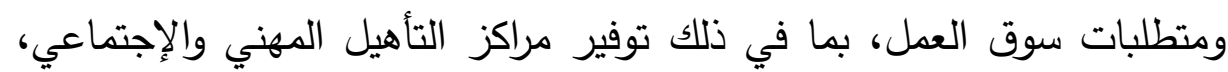

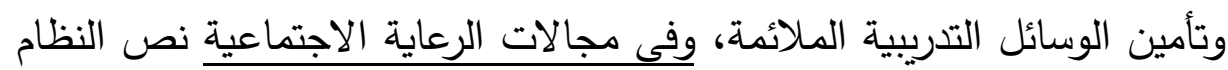

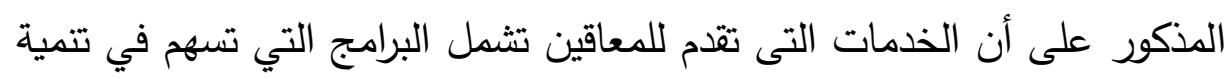
قدرات المعوق، لتحقيق إندماجه بشكل طبيعي في مختلف نواحي الحياة العامة،

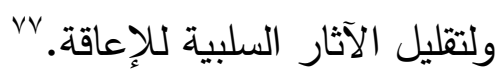

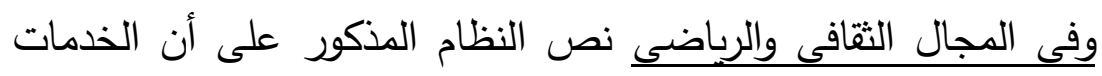

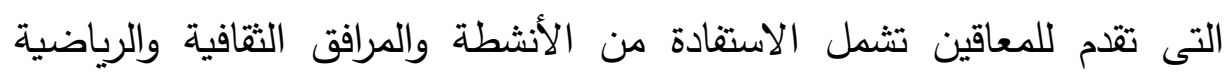

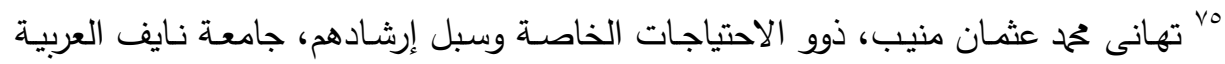

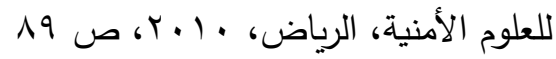
بv مشاعل سفاح مطارد الحربى، واقع الخدمات التعليميـة لطسلاب الجامعـة ذوى الاحتياجـات

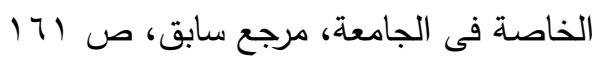

عVد عبديز بن يوسف المطلق، حقوق ذوى الاحتياجات الخاصة فى النظام السعودى (دراسة

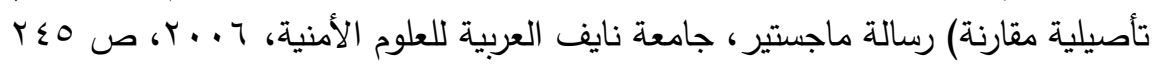


وتهيائتها، ليتمكن المعوق من المشاركة في مناشطها داخلياً وخارجياً بما يتتاسب

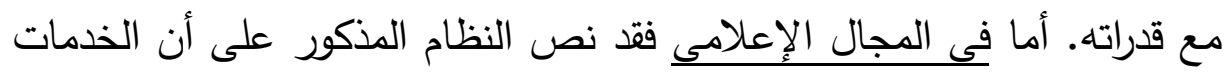
التى تقدم للمعاقين تشمل قيام وسائل الإعلام المرئية والمسموعة والمقروهة

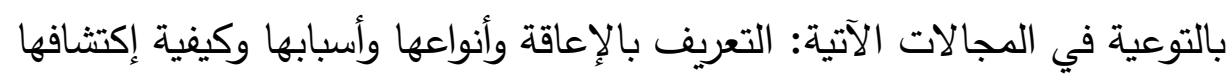

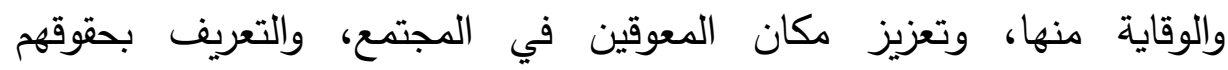
واحتياجاتهم، وقدراتهم، وإسهاماتهم، وبالخدمات المتاحة لهم، وتوعيتهم بواجباتهم

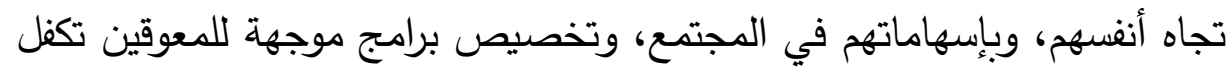

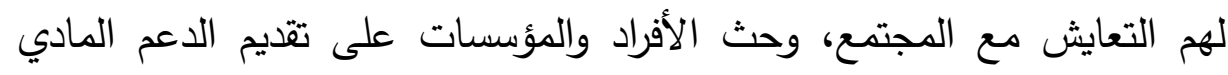

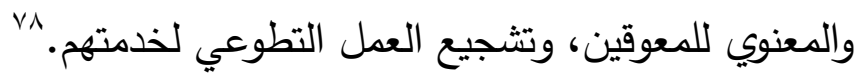

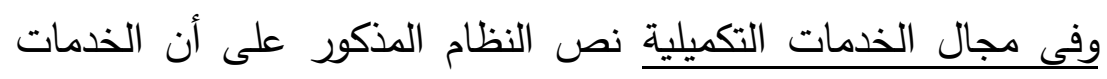
التى تقدم للمعاقين تشمل تهيئة وسائل المواصلات العامة لتحقيق تتقل المعوقين بأمن وسلامة وبأجور مخفضة للمعوق ومرافقه حسب ظدروف تلفئ الإعاقة، وتقديم

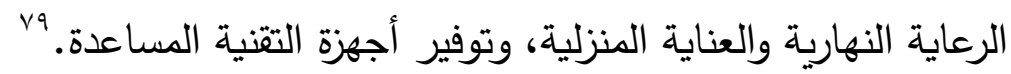
كما أجاز النظام أن تمنح الدولة المعوقين قروضاً ميسرة للبدء بأعمال

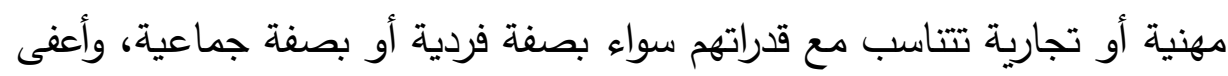

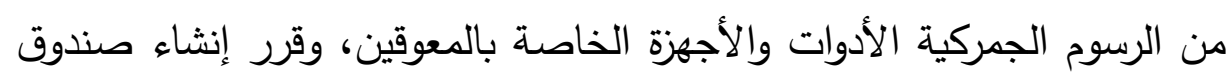

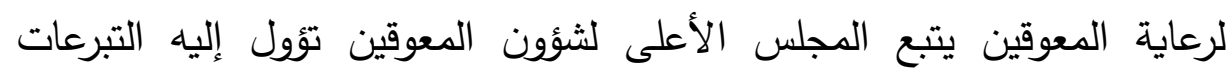
والهبات والوصايا والأوقاف والغرامات المحصلة عن مخالفة التنظيمات الخاصة الألي بخدمات المعوقين.

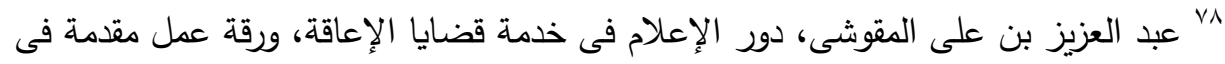

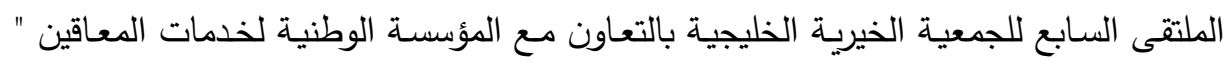

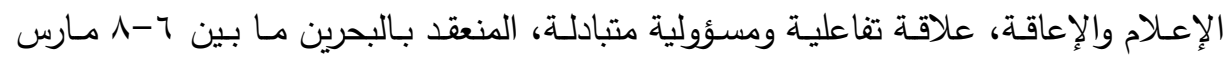
70 ص r...V

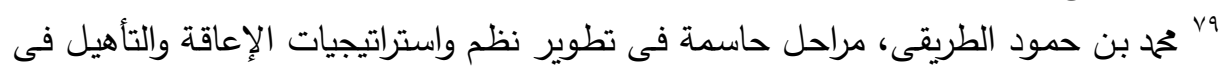

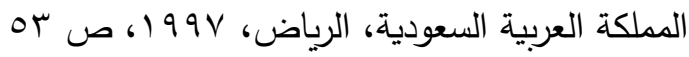

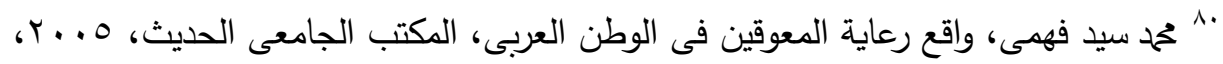
ص س 1919 I TON

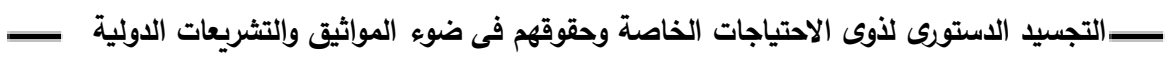

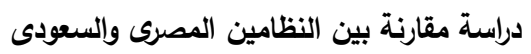


أما المجلس الأعلى لثؤون المعوقين فهو يرتبط برئيس مجلس الوزراء،

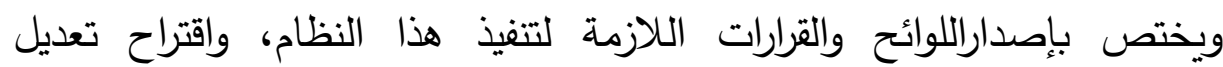
النصوص النظامية المتعلقة بشؤون المعوقين في المجالات المختلفة، وإقتراح

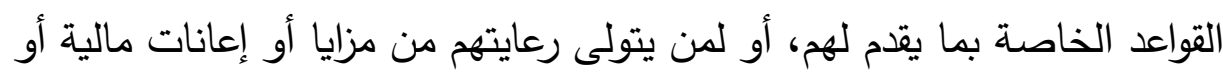

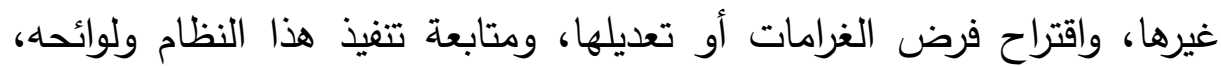

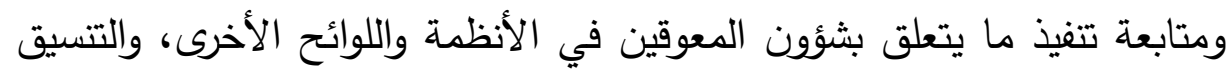

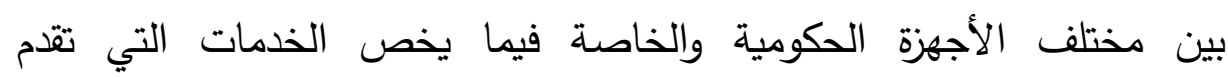
للمعوقين، وتشجيع البحث العلمي للتعرف على حجم الإعاقة، وأنواعها وأسبابها، ووسائل الوقاية منها، وطرق علاجها والتغلب عليها أو الحد من آثارها السلبية، وكذلك تحديد أكثر المهن ملاعمة لتدريب وتأهيل المعوقين بما يتفق ودرجات إعاقاتهم وأنواعها ومتطلبات سوق العمل، وتثجيع المؤسسات والأفراد على إنشاء

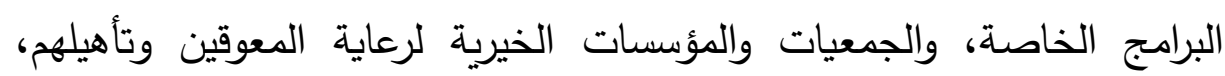
ودراسة التقارير السنوية التي تصدرها الجهات الحكومية المعنية فيما يتعلق بما تم إنجازه في مجالات وقاية المعوقين وتأهيلهم ورعايتهم، واتخاذ اللازم بشأنه،

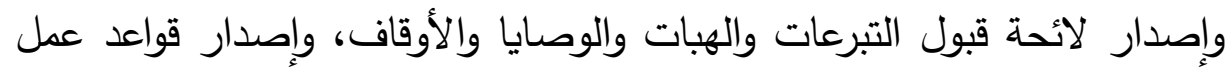

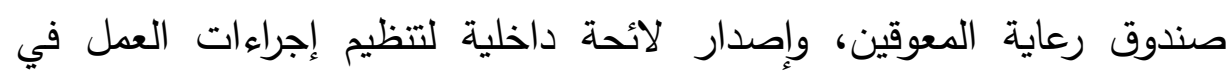

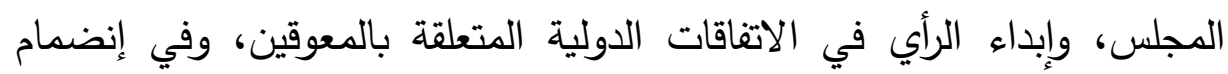
المملكة إلى المنظمات والهيئات الإقليمية والدولية ذات العلاقة بشؤون رعاية المعوقين.

\section{نتائج الاراسة}

ا ـ يدمج كل من القانون المصرى والنظام السعودى بين النمطين الطبى والاجتماعى للإعاقة، إذ يرتبهما الأول بشكل صريح بينما يعتبر الثانى أن تعدد الإعاقة

ای عبدالعزيز بن يوسف المطلق، حقوق ذوى الاحتياجات الخاصة فى النظام السعودى، مرجع 
إصابة تستدعى رعاية صحية، كما يعتبر كل من القانون المصرى والنظام السعودى الفرد المعاق هو من أصابه القصور جزئيا كان أم شاملا على وجله الاستقرار، فديمومة القصور هى التى تمنعه من تحصيل حقه لوجود عواق تحول دون تلبية احتياجاته كغيره، وهو ما يتوافق مع التعريف الاجتماعى للإعاقة ومضامين الأجل الطويل. r. ذوو الاحتياجات الخاصة ما هم إلا أشخاص معاقين قد فقدوا القدرة الفعلية أو الو العقلية أو الاجتماعية والنفسية أو الجسمية وأصبحوا بحاجة إلى التى نوع من الخدمات والرعاية لتعويض الجزء المفقود منهم. r. لم يفرق القانون المصرى بين مصطلح التأهيل ووسائله، كما أن للتأهيل أساليب يستخدمها المتخصصون فى التعامل مع ذوى الاحتياجات الخاصة، وذلك له

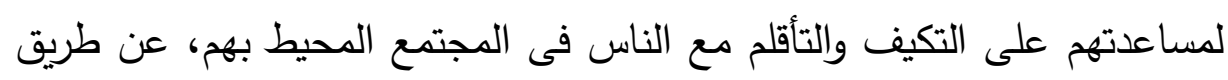
دمجهم فى بيئتهم المتواجدون بها ومساعدة أهلهم فى معرفة التعامل معهم. ع. وضعت الاتفاقية الدولية لحقوق الأشخاص ذوى الإعاقة تنظيماً شاملاً وكاملاً

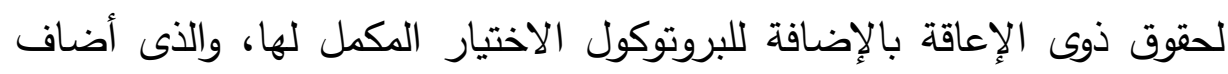
للآلية الخاصة بتطبيق الاتفاقية لجنة معنية بحقوق الأفراد ذوى الإعاقة، حيث الإصن أضاف لها الاختصاص بتلقى الثكاوى أو الرسائل التى تقدم من قبل أو نيابة عن الأشخاص الخاضعين لولاية دولة طرف ويذكرون فيها أنهم ضحايا لانتهاك الحقوق المنصوص عليها الاتفاقية. 0. اهتمت مصر بذوى الاحتياجات الخاصة حيث يتضمن الدستور $1(1$ مادة واضحة

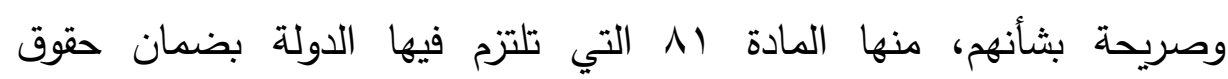
الأشخاص ذوي الإعاقة، والمادة سه التي تتص على أنّ المواطنين لادى القانون

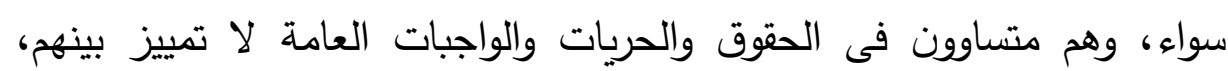
والمادة ـ ج من الدستور ذاته والخاصة بالأطفال إذ تم وضع فقرة خاصة برعاية 
الأطفال ذوى الإعاقة، وبذلك ضمن الدستور لهذه الفئة الحقوق والحريات وتوفير فرص العمل، وتمكينهم من المساواة مع غيرهم ودمجهم في التعليم. 7. تراعى المادة ام من الدستور المصرى المعايير الدولية فى هذا الثأن كالتأهيل والدمج والمباديء الدولية ذات الصلة كالمساواة مع الآخرين والعدل وتكافؤ الفرص، وقد أضاف قانون حقوق الأشخاص ذوى الإعاقة تفسيرا للدمج بأنه

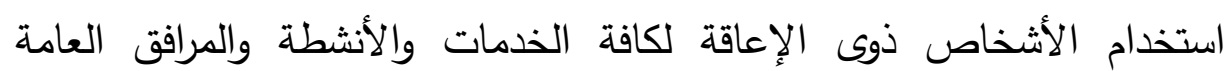
ووسائل التعليم، على قدم المساواة مع الآخرين فى المجتمع، دون إقصاء أو الإهاه استبعاد فى شتى مناحى الحياة من خلال السياسات والخطط والتدابير والبرامج المناسبة والتوعية المجتمعية والمشاركة الفعالة.

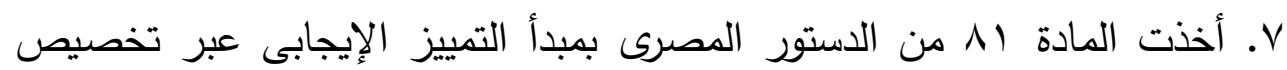
حصة (كوتا) للتشغيل، وقد ترك الدستور المصرى للمشرع القانونى مهمة تحديد نسبة ذوى الإعاقة فى المجالس المحلية والنيابية مقيدا إياه بكونها مناسبة أو ملائمة، على عكس نهج الدستور فيما يخص التمييز الإيجابى للمرأة والثباب الابه لئه على الرغم من أن التمييز الإيجابى لهما يتسم بكونه مؤقت حتى يصبح عرفا اجتماعيا، بينما يظل التمييز الإيجابى دائما لذوى الإعاقة، فضل عن أن الن معيارا التناسب والتلائم قد يثير الخلاف حول تفسيرهما ويفتح الباب أمام شبهات عدم الإع الدستورية. ^. تتص المادة ؛ من قانون حقوق الأشخاص ذوى الإعاقة المصرى - على طولها

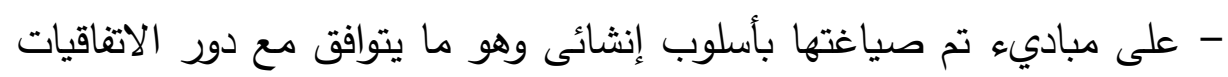

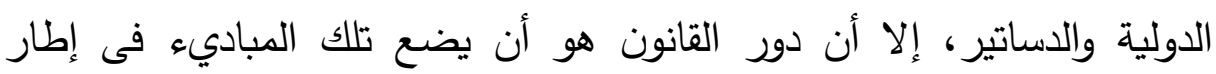
تتفيذى - لا فى الإطار الدعائى - الخطوات والإجراءات اللازم أخذها.

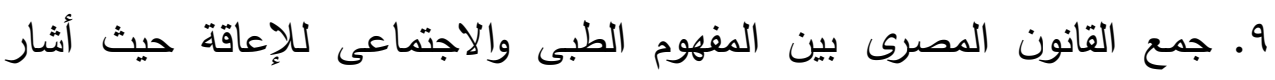
لإصدار وزارة التضامن الاجتماعى بالتتسيق مع وزارة الصحة والسكان لكل معاق بطاقة إثبات الإعاقة والخدمات المتكاملة مع إعداد ملف صحى. 


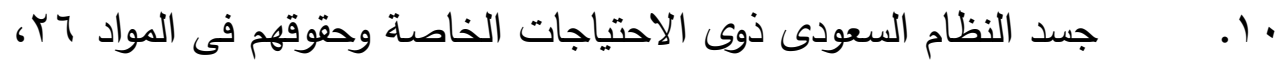
ف TV النظام الأساسى، فضلا عن تفصيل نظام رعاية شؤون المعوقين لحقوقهم فى شتى المجالات كالمجال الصحى والتعليمى والرعاية الاجتماعية والثقافة

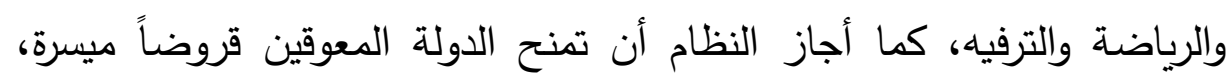

وربط المجلس الأعلى لثؤون المعوقين برئاسة الوزراء. توصيات الاراسة

ا ـ من الأفضل للمشرع الدستورى المصرى أن يحدد نسبة - أو الحد الأدنى تمثيل ذوى الاحتياجات الخاصة فى المجالس النيابية والمحلية. r. إعادة النظر فى صياغة المادة ء من قانون حقوق الأثخاص ذوى الإهي الإعاقة المصرى لتتحول من الأسلوب الدعائى لخطوات تنفيذية. r. زيادة الأبحاث التى تهدف لوضع نظرية عامة لحقوق ذوى الاحتياجات الخاصة.

\section{المراجع}

\section{أولا: المراجع باللغة العربية}

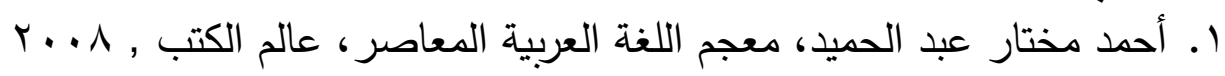

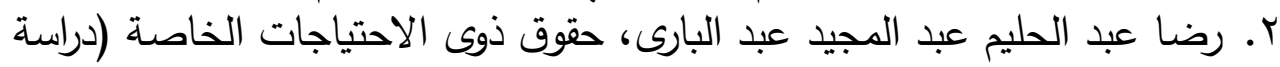

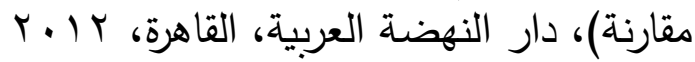

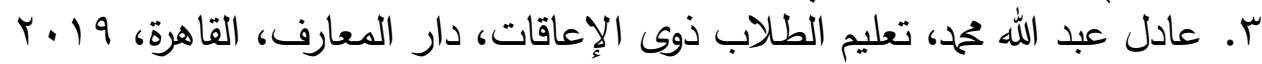

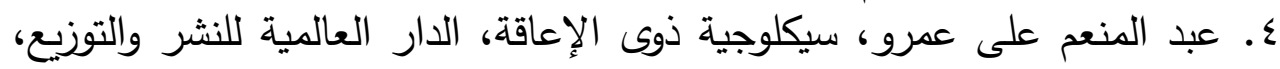

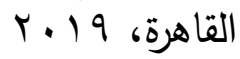
๑. محمد بن حمود الطريقى، مراحل حاسمة فى تطوير نظم واستراتيجيات الإعاقة

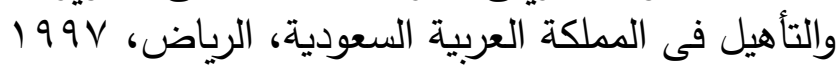

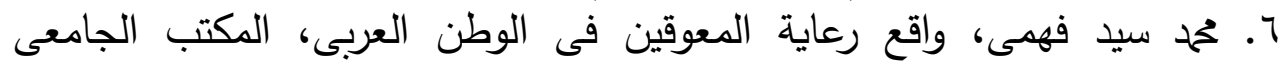

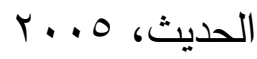

I rY

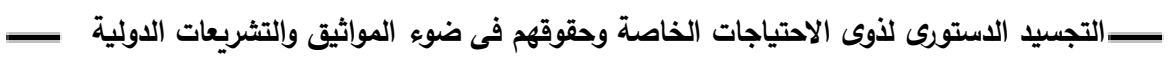

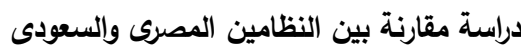


V. محمود شريف بسيونى، الوثائق الدولية المعنية بحقوق الإنسان، المجلد الثانى،

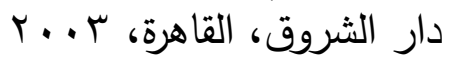

\section{الرسائل الجامعية - (الرية}

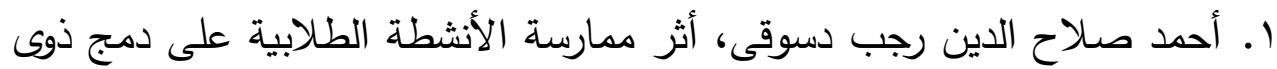

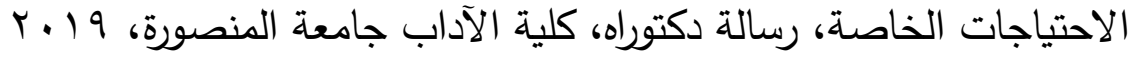

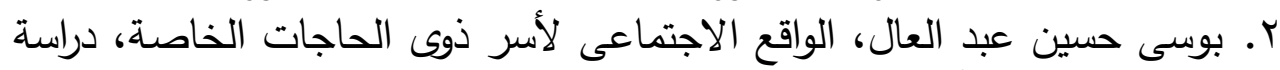

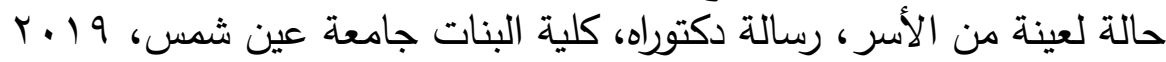

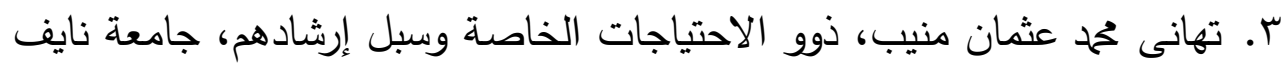

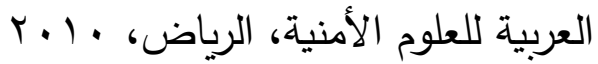

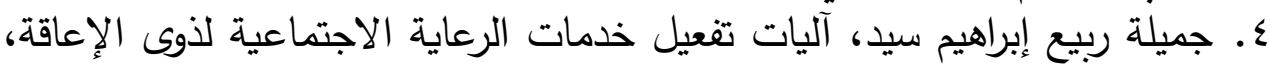

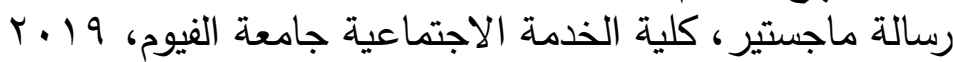

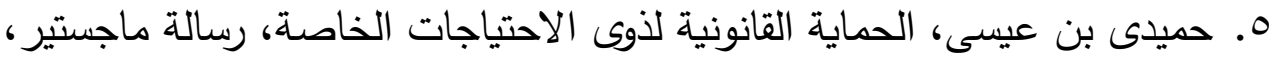

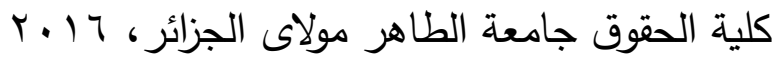

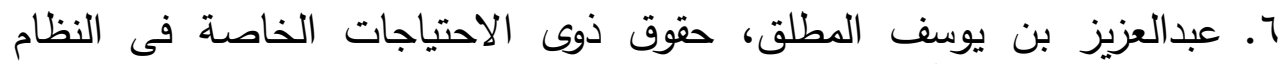

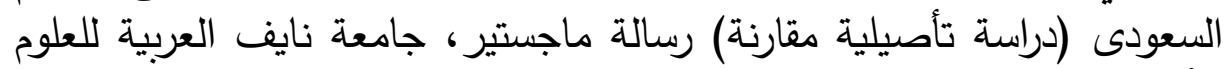

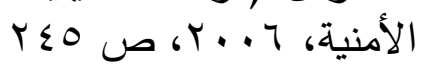

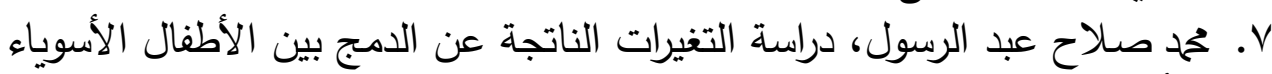

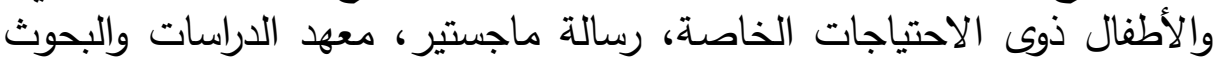

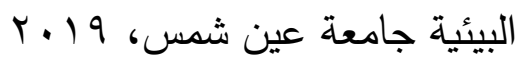

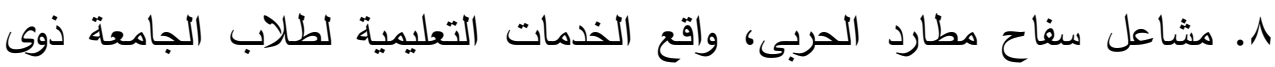

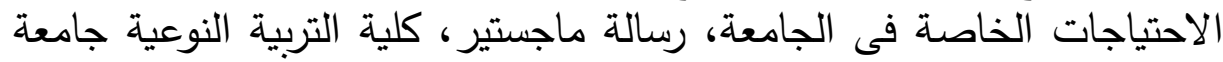

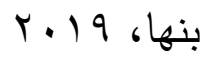

9 9. مصطفى محمود إبراهيم محمود، العدالة الاجتماعية كمدخل لمناهضة الإنة الاستبعاد

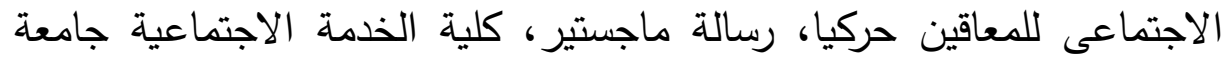

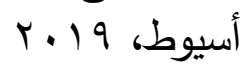

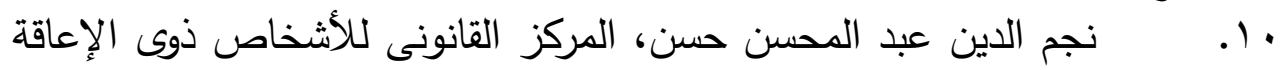

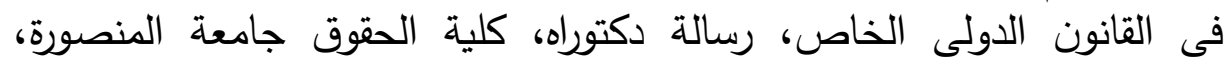

11. هبة عاطف السيد محمود عوض، دور الجمعيات الأهلية فى تفعيل

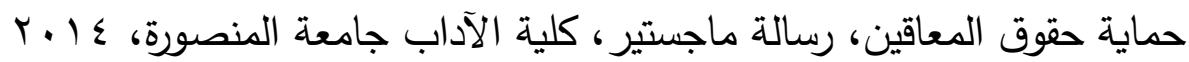

المقالات والأبحاث المقاث 


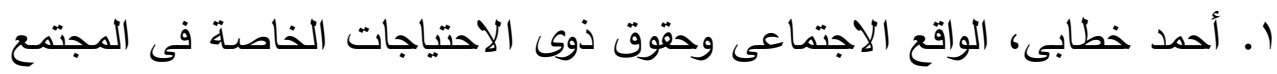

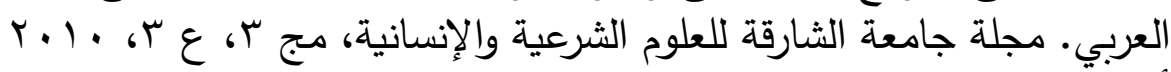

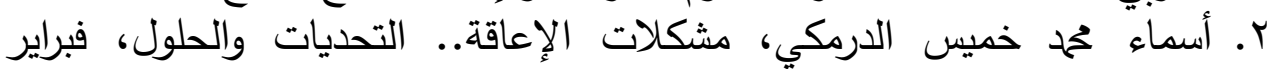

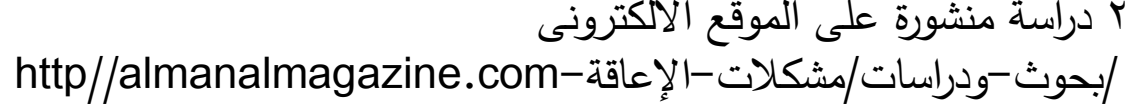
التحديات -والحلول/almanalma

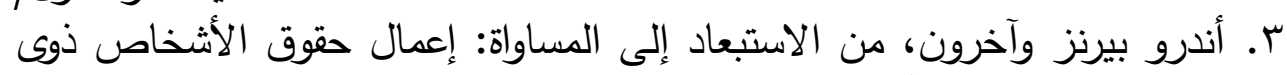

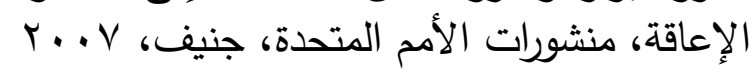

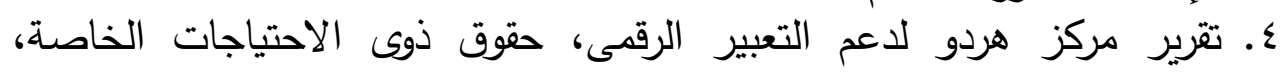

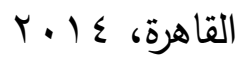

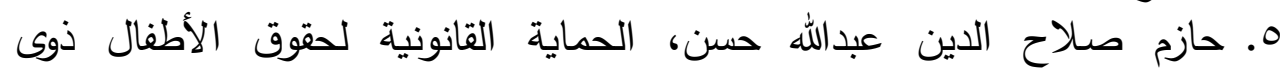

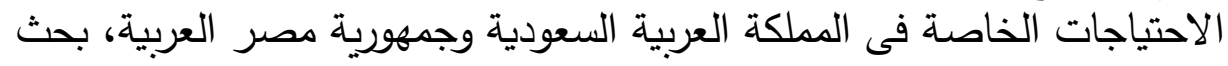

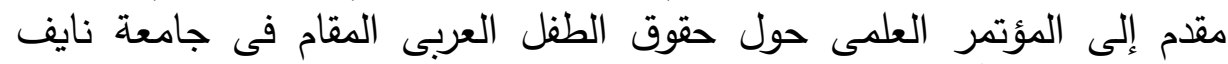

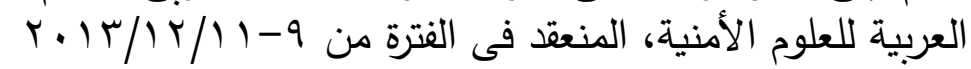

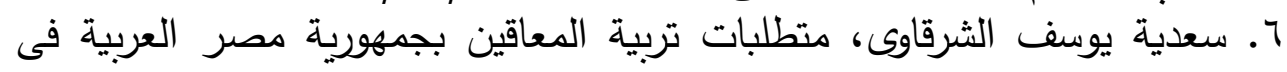

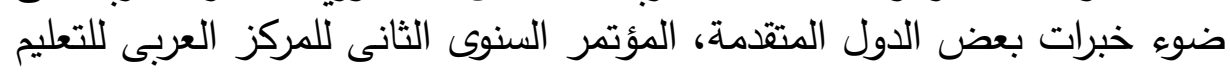

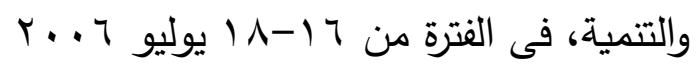

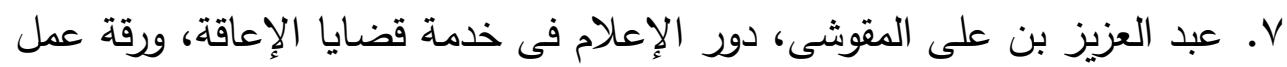

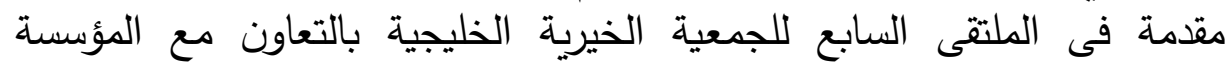

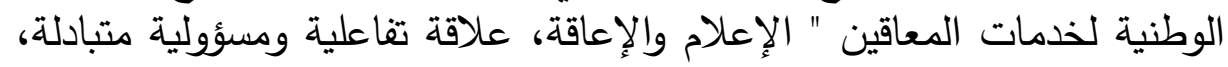

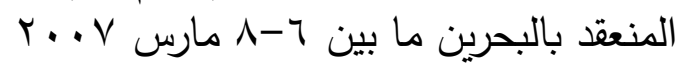

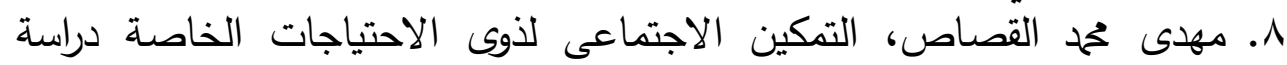

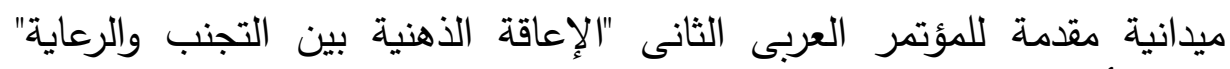

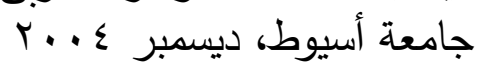
9. وسيم حسام الدين الأحمد , الحماية القانونية لحقوق الحقية المعاقين ذوى الاحتياجات

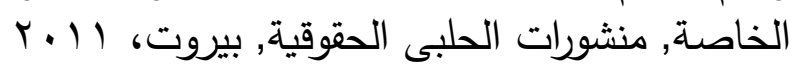
المواثيق الدولية والوطنية منثوات الحلبي 1. اتفاقية حقوق الأشخاص ذأيق ذالوى الإعاقة اعتمدت بموجب قرار الجمعية العامة للأمم

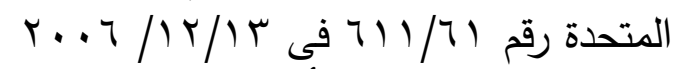

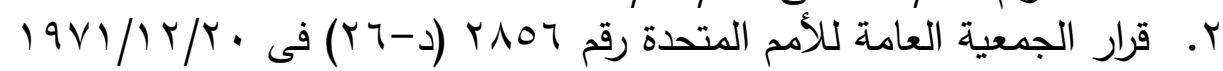

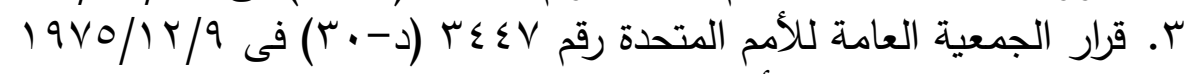

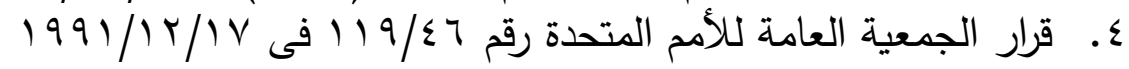




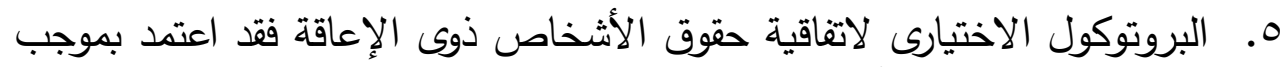

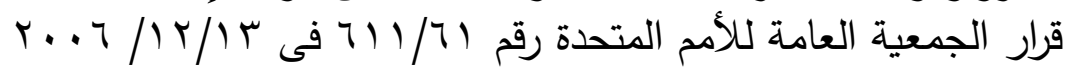

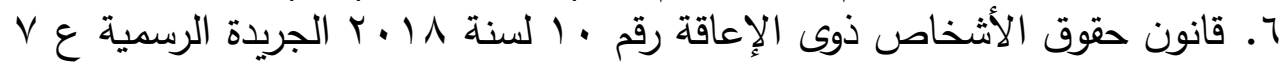

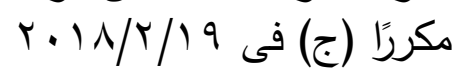

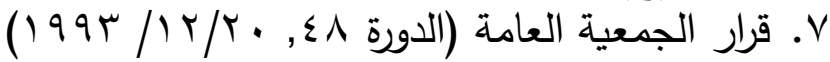

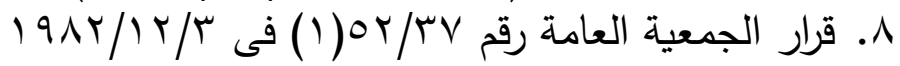

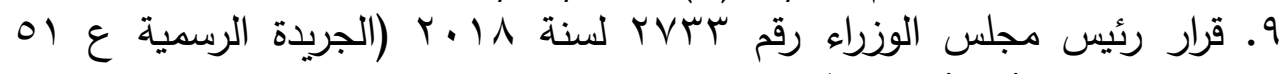

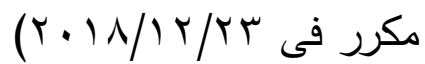

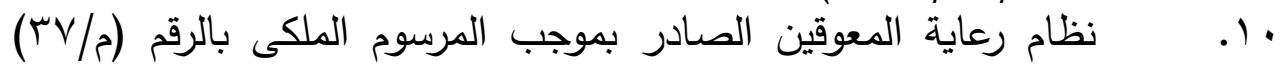

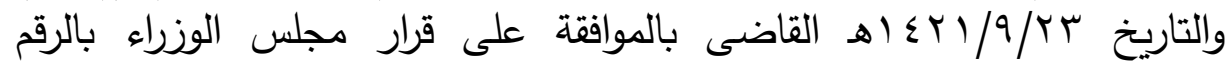

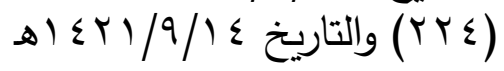

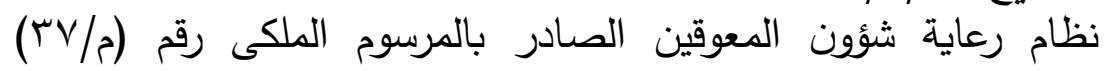

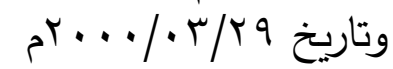
ثانتيا: المراجع باللغة الإنجليزية

1. Amy Raub, Isabel Latz, Constitutional Rights of Persons with Disabilities: An Analysis of qr National Constitutions, Harvard Human Rights Journal, Vol. Yq, r. 17

r. Blanck B, Wilichowski A and Schmeling J, 'Disability Civil Rights Law and Policy, William \& Mary Bill of Rights Journal, I $r(r)(r \ldots \varepsilon)$

r. ChoudharyLaxmi Narayan, Thomas John, The Rights of Persons with Disabilities Act, Does it address the needs of the persons with mental illness and their families, Indian Journal of Psychiatry, o9( ( ): IV, January $Y .1 \mathrm{~V}$

£. Clement Marumoagae, Disability Discrimination and the Right of Disabled Persons, P.E.R vol. 10, no 1, DOI:

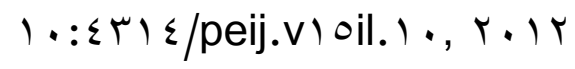

๑. Colker, Ruth and Milani, Adam. Everyday Law for Individuals with Disabilities, Paradigm Publishers, Y...

7. De Paor, Aisling, and Charles O'Mahony. The Need to Protect Employees with Genetic Predisposition to Mental Illness? The UN Convention on the Rights of Persons with 


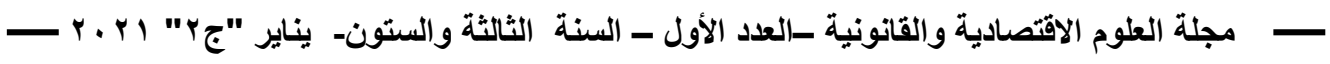

Disabilities and the Case for Regulation. Industrial Law Journal , $\leqslant 0, r .17$

$\vee$. Degener, Theresia. Disability in a Human Rights Context. Laws (0) (ro), r. 17

^. Dorothy Estrada-Tanck, Human Rights of Persons with Disabilities in International and EU Law, Academy of European Law, $r \cdot 17$

१. Fleischer, Doris Zames and Zames, Frieda. The Disability Rights Movement: From Charity to Confrontation, Temple University Press, ${ }^{\text {nd }}$ ed., r. 11

1.. Gupta, Shivani, Meenakshi Balasubramaniam, Sudha Ramamoorthy, Rama Chari, and Bhargavi Davar. Monitoring Report of Civil Society, United Nations Convention on Rights of Persons with Disabilities-India. $r \cdot 1 r$

11. Harpur, Paul, and Richard A. Bales. The Positive Impact of the Convention on the Rights of Persons with Disabilities: A Case Study on the South Pacific and Lessons from the U.S. Experience. Northern Kentucky Law Review (rV) $r \cdot 1$.

IY. House of Lords Library Briefing, Disability in the UK: Rights and Policy Debate, Report June $r \cdot 1 \wedge$

1T. Inclusion Scotland, Disability Rights UK and Disability Wales, Implementation of the United Nations Convention on the Rights of Persons with Disabilities Alternative report Great Britain, January $Y . I V$

I . J J Beqiraj, L McNamara and V Wicks, Access to justice for persons with disabilities: From international principles to practice, International Bar Association, October $r .1 \mathrm{~V}$

10. Kalpana Kannibiran, Monitoring the Human Rights of Persons with Disabilities: Laws, Policies and Programs in India, Disability Rights Promotion International (D.R.P.I.) r. . 9

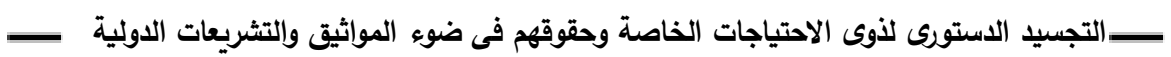

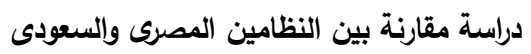




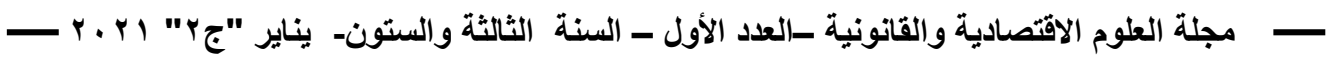

17. Lang, Raymond, Maria Kett, Nora Groce, and JeanFrancois Trani, Implementing the United Nations Convention on the rights of persons with disabilities: Principles, implications, practice and limitations. ALTER-European Journal of Disability Research $r.\urcorner, r .11$

IV. Longmore, Paul, K. and Umansky, Laurie, editors, The New Disability History: American Perspectives, New York University Press, Y...

1^. Mark C. Weber, Protection for Privacy under the United Nations Convention on the Rights of Persons with

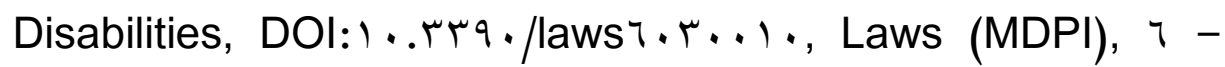
1. August r. IV

19. Mégret, Frédéric. The Disabilities Convention: Toward a Holistic Concept of Rights, International Journal of Human Rights, (I Y) Y. II

r.. O'Brien, Ruth. Crippled Justice: The History of Modern Disability Policy in the Workplace, University Of Chicago Press,,$\ldots$. I

r). Penelope Weller, The Convention on the Rights of Persons with Disabilities and the Social Model of Health: New Perspectives, DOI: 1 . rIrq/ssrn. r) $\leq r r r r, ~ S S R N$ Electronic Journal, January $r \cdot 11$

rr. Perlin, Michael. International Human Rights Law and Comparative Mental Disability Law: The Universal Factors. Syracuse Journal of International Law and Commerce ( $r \varepsilon)$, r...V

rr. Sara Tonolo, The protection of persons with disabilities in private international law, Cuadernos derecho transnational, March $r .1 r$

ثالثًا: مواقع الإنترنت

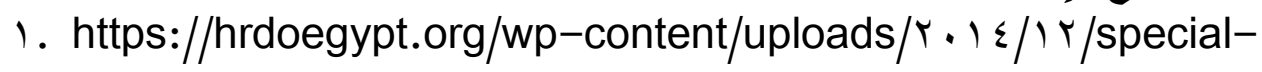
needs

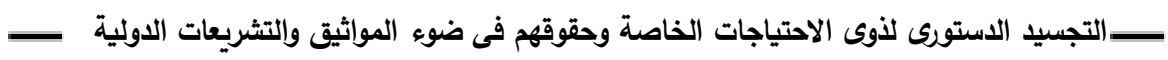

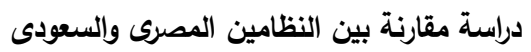

